Vanessa Nunes de Paiva

\title{
Participação das Citocinas Th1 e Th2 na Lesão de Isquemia e Reperfusão Renal
}

Dissertação de mestrado apresentada ao Instituto de Ciências Biomédicas da Universidade de São Paulo, para obtenção do Título de Mestre em Ciências (Imunologia)

São Paulo

2008 


\title{
Vanessa Nunes de Paiva
}

\section{Participação das Citocinas Th1 e Th2 na Lesão de Isquemia e Reperfusão Renal}

\author{
Dissertação de mestrado apresentada ao Insti- \\ tuto de Ciências Biomédicas da Universidade de \\ São Paulo, para obtenção do Título de Mestre \\ em Ciências
}

Área de concentração: Imunologia

Orientador: Prof. Dr. Niels Olsen Saraiva Câmara

São Paulo

2008 
DADOS DE CATALOGAÇÃO NA PUBLICAÇÃO (CIP)

Serviço de Biblioteca e Informação Biomédica do

Instituto de Ciências Biomédicas da Universidade de São Paulo

reprodução não autorizada pelo autor

Paiva, Vanessa Nunes de.

Participação das citocinas Th1 e Th2 na lesão de isquemia e reperfusão renal / Vanessa Nunes de Paiva. -- São Paulo, 2008.

Orientador: Niels Olsen Saraiva Câmara.

Dissertação (Mestrado) - Universidade de São Paulo. Instituto de Ciências Biomédicas. Departamento de Imunologia. Área de concentração: Imunologia. Linha de pesquisa: Transplante.

Versão do título para o inglês: Participation of Th1 and Th2 cytokines ischemia and reperfusion injury of kidney.

Descritores: 1. Ischemia 2. Citocinas 3. Linfócitos T 4. Rim I. Câmara, Niels Olsen Saraiva II. Universidade de São Paulo. Instituto de Ciências Biomédicas III. Título. 
Candidato(a):

Título da Dissertação:
Vanessa Nunes de Paiva.

Participação das citocinas Th1 e Th2 na lesão de isquemia e reperfusão renal.

Orientador(a): $\quad$ Niels Olsen Saraiva Câmara.

A Comissão Julgadora dos trabalhos de Defesa da Dissertação de Mestrado, em sessão pública realizada a .................................,
( ) Aprovado(a)
( ) Reprovado(a)

Examinador(a): Assinatura:

Nome:

Instituição:

Examinador(a): Assinatura:

Nome:

Instituição:

Presidente: Assinatura:

Nome:

Instituição: 
Dedico esta dissertação de mestrado a um homem inesquecível e mais maravilhoso que já conheci em toda minha vida: Ao meu avô Adjaime Ludovino da Silva, que foi uma pessoa que me criou com muito amor, carinho e dedicação, que acompanhou meus primeiros passos, que me mostrou a beleza da simplicidade da vida, me fez acreditar que tudo vale a pena, sempre muito calado e de pouca conversa, mas seu silêncio falava em pequenos gestos com amor. Uma pessoa que me orgulho por ter sido um pai de família, companheiro, sempre presente e trabalhador de lavoura sempre suado, com mãos grossas e pele queimada do sol me ensinou um bem precioso que é ser sincera, ter caráter e coragem para enfrentar as dificuldades. Deus o levou para um lugar sereno e calmo apenas três meses do inicío do meu mestrado, mas tenho certeza que foi melhor o descanso ,que é o que você merece, sinto saudades, mas as lembraças são o suficiente para guardar o eterno amor que sinto por você em meu coração. Mesmo você não estando aqui para ver o bem que acabo de realizar sei que você esta ai em cima orgulhoso de mim. A você vô meu eterno e sincero agradecimento por tudo que você fez por mim e pelos meus irmãos e pela pessoa que consegui ser hoje. 


\section{Agradecimentos}

Ao Prof. Dr. Niels Olsen Saraiva câmara, pela compreensão, orientação, amizade, por acreditar em mim e principalmente por ter me dado a oportunidade de hoje ser a sua primeira aluna de mestrado a defender tese aqui em seu laboratório na USP e aprendi muito durante o desenvolvimento do meu mestrado.

Aos meus pais Maria José costa da Silva e José Nunes de Paiva, que foram minha fonte de apoio, amor infinitos, coragem e que acreditaram em mim sempre.

Aos meus irmãos Marcelo, Alexander, Anderson Cleiton e minha irmã Priscila, pelo apoio, carinho e paciência.

À minha avó Maria Aparecida Costa da Silva que também auxílio meu avô a me criar com muito amor e carinho, esta sempre presente, cuidando e orando por mim em todos momentos.

E sem ajuda da aluna de doutorado da UNIFESP Rebecca Medeiros esse trabalho não teria sido tão completo, pois agradeço a imensa paciência e dedicação que a Rebecca teve em me ensinar técnicas que foram essencias para realização deste trabalho, além de uma pessoa super copetente e profissional a Rebecca também é uma amiga que jamais irei esquecer, pois quando ela chegou no laboratório eu era a única aluna do laboratório do professor Niels e tinha muito trabalho a fazer e Rebecca me ensinou simplismente tudo que ela sabia. Com ela aprendi ser uma pessoa ética na pesquisa e acreditar que sempre vale a pena tentar sem medo de errar.

Aos amigos de laboratório: Mariane, Gabi, Gian Carlo obrigado por tudo que me 
ensinaram, principalmente por mostrarem que nenhuma pesquisa se faz sozinha e muito menos de mau humor.

Ao aluno de doutorado do laboratório Rafael Larocca por ser uma pessoa super prestativa sempre pude contar com ele até mesmo nas horas mais complicadas e pela convivência maravilhosa.

À aluna de iniciação cientifica Mayra Carvalho Ribeiro que tive o prazer de conhecer durante um curso que fui monitora e logo a convidei a vir trabalhar no grupo, ela aprendeu muito comigo e eu também aprendi muito com ela, com sua coragem e dedicação você vai longe e obrigada por me auxiliar nas horas mais complicadas.

À técnica do nosso laboratório Claudinha uma pessoa alegre sempre.

Ao técnico do irradiador Rogério que sempre teve paciência com meus protocólos.

À Dra Silvia Maria Gomes Massironi e Regina de Luca, pelas ajudas nos pedidos infinitos de camundongos.

Ao Paulo da histologia pela realização das minhas lâminas, pois sem elas meus dados ficariam imcompletos.

Às secretárias Jotelma e Eni, por todo apoio burocrático e amizade.

Ao secretário Amarildo pelos favores e paciência.

Aos amigos do departamento que de alguma forma compartilhamos conhecimentos, festinhas, viagens, congressos, projetos, cursos, discussões: Cristian, André Bombeiro, Alexandra, Sheylla, Tatiana Takishi, Josias, Julieta e Gabriela Tonini que fizemos um trabalho interessante juntas e com resultados promissores.

À uma amiga que conheci em botucatu na época de graduação que até hoje nunca mais nos separamos Adriana Restelli.

Aos meus amigos de Ribeirão Preto que já estão presentes em minha vida a mais de uma década, Viviane Colombari, Silvia, Camila, Magrão e Karen Santiago. À uma amiga imcomparavél que conheci por conhecidência da vida estudando imunologia, tive 
o prazer de trabalhar e estudar por 2 anos com ela, a Érica Souza Fernandes, pude contar com ela para tudo para discussão de matérias, viagens, auxílios financeiros nas emergências, na verdade ela se tornou para mim uma irmãozona.

Aos professores do Departamento de Imunologia do ICB-IV USP pelos conhecimentos transmitidos.

Ao caseiro e amigos da pensão onde morei boa parte durante meu mestrado, Senhor Benedito, Antônio, Mineiro e Diego.

Ao meu adoravél noivo Roberto Linares, que é uma pessoa que palavras não o define, simplismente ele é uma pessoa carinhosa, companheira, sempre disposto a escutar minhas aulas e me ajudar na formatação da tese, sempre dando conselhos e tem muita paciência comigo, com ele ao meu lado amadureci muito e pude ver que o amor também educa, ensina que o amor ele não engana, ele comprende e que te conhecer foi a melhor coisa que pode acontecer durante o meu mestrado e que esse amor dure para sempre.

Aos amigos do Roberto que conheci aqui na USP no instituto de Física, Edmilson e seus churrascos, baiano, Maria Carmem, Kelly, Luciano, Giu, Gabriel, Bob e Fábio.

À Dra Patricia pela realização da técnica de bioplex e pela amizade.

Aos amigos do departamento de nefrologia da UNIFESP que foi onde inicíou o meu trabalho com lesão de I/R renal, Giselle Gonçalves que me ensinou a técnica de isquemia, Carla Feitosa, o técnico Marcos Cenedeze que me auxílio em vários experimentos, Amanda e ao bioterista Mauro que sempre me deu uma força com meus camundongos no biotério da UNIFESP.

À Professora Dra Iêda do Departamento de Imunologia, Microbiologia e Parasitologia da UNIFESP que me ensinou também técnicas de transferência adotiva de linfócitos.

Às agências de fomento FAPESP e CNPq pelo auxílio financeiro, sem elas iria ficar dificíl de morar em São Paulo e realizar esse trabalho. 


\section{Momentos na Vida}

"Há momentos na vida em que sentimos tanta a falta de alguém que o que mais queremos é

tirar esta pessoa dos nossos sonho e abraça-la.

Sonhe com aquilo que você quiser.

Seja o que você quer ser, por que você possui apenas uma vida e nela só se tem uma chance

de fazer aquilo que se quer.

Tenha felicidade bastante para fazê-la doce.

Dificuldades para fazê-la forte.

Tristeza para fazê-la humana.

E esperança suficiente para fazê-la feliz.

As pessoas mais felizes não têm as melhores coisas.

Elas sabem fazer o melhor das coisas oportunidades que aparecem em seus caminhos.

A felicidade aparece para aqueles que se machucam.

Para aqueles que choram.

Para aqueles que buscam e tentam sempre.

E para aqueles que reconhecem a importância das pessoas que passasm por suas vidas.

O futuro mais brilhante é baseado num passado intensamente vivido.

Você só terá sucesso na vida quando perdoar os erros e as decepções do passado.

A vida é curta, mas as emoções que podemos deixar duram uma eternidade.

A vida não é de se brincar por que um belo dia se morre."

Clarice Lispector 
Aos Camundongos, pois sem eles minha tese não teria se quer uma página, eles são fofos e adoravéis.

" O bem estar animal precisa de pessoas educadas, com cabeças frias e corações quentes, preparadas para ver o sofrimento dos animais e procurar meios práticos para aliviá-los" Chales Heme, 1926 


\section{Resumo}

A lesão renal induzida pela I/R é a principal causa de IRA nos rins nativos e nos rins transplantados e estudos enfatizam a participação de células inflamatórias na sua patogênese, através da caracterização de lesão endotelial, infiltração leucocitária e a geração de mediadores inflamatórios pelas células epiteliais tubulares. Evidências recentes mostram que as células T CD4+ exercem um papel fundamental como mediadoras da agressão renal na I/R, ressaltando-se o envolvimento do paradigma Th1/Th2 como um possível mecanismo efetor.

O presente estudo foi realizado com o objetivo de estudar a participação de algumas citocinas Th1 e Th2 no desenvolvimento da lesão de I/R renal. Para tanto, nós nos propusemos a desenvolver um modelo experimental de $\mathrm{I} / \mathrm{R}$ renal em camundongos deficientes em IL-12, IFN- $\gamma$, e duplo deficientes em IFN- $\gamma$ e IL-12 (representando defeito da via de ativação Th1), camundongos deficientes em IL-4 e IL-10 (representando defeito da via de ativação Th2) e duplo deficientes em IL-10 e IL-12, tendo como controles camundongos normais (selvagens). Todos os animais foram submetidos a uma lesão de I/R por ligadura reversível do pedículo renal por 45 minutos seguidos de 24 horas de reperfusão. Após a indução da isquemia, nós analisamos as alterações funcionais (creatinina e uréia por método bioquímico colorimétrico) e morfológicas renais (morfometria renal), além de investigar a expressão molecular de HO-1 (um gene de proteção tecidual), de t-bet (um transcrito envolvido na diferenciação Th1), de GATA-3 (um transcrito envolvido na diferenciação Th2), citocina pró-inflamatória IL-6 e de uma 
quimiocina pró-inflamatória MCP-1, visando caracterizar a influência da polarização Th1/Th2 da resposta imune na lesão renal induzida pela I/R.

Nós mostramos que os camundongos deficientes em IL-4, IFN- $\gamma$, IL-10/IL-12 e IL-10 apresentaram uma disfunção renal importante, caracterizada por altos níveis séricos de creatinina e uréia e por um alto grau de agressão morfológica renal, avaliada pela percentagem de área de necrose tubular. Todos estes resultados foram significantemente mais acentuados que obtidos nos camundongos deficientes em IL-12 e IFN- $\gamma /$ IL12, sendo comparáveis aos animais selvagens. Por outro lado, a capacidade de reparação renal, medida pela percentagem de área de regeneração tubular, foi mais precoce nos camundongos deficientes em IFN- $\gamma$, quando comparada com os camundongos deficientes em IL-12 e IFN- $\gamma /$ IL-12. A análise molecular quantitativa, utilizando-se o PCR em tempo real mostrou uma expressão significantemente maior de RNAm de HO-1, IL-6 MCP-1 e do fator transcricional pata Th2 (GATA-3) nos camundongos deficientes em IL-4, IFN- $\gamma$, IL-10/IL-12 e IL-10, em comparação com os camundongos deficientes em IL-12, IFN- $\gamma /$ IL-12 que apresentaram baixa expressão do fator transcricional para Th1 (T-bet), em 24 horas após a I/R renal.

Quando fomos fazer a transferência adotiva de médula óssea de animais deficientes em IL-12 e IL-4 para animais selvagens previamente com depleção subletal celular, esses animais vieram apresentar resultados semelhantes aos animais deficientes em IL-12 e IL-4, onde os animais selvagens recontituidos com medula óssea dos animais IL-12 apresentaram menor níveis de uréia sérica e menor eexpressão de RNAm IL-6, enquanto que os animais selvagens recontituídos com medula óssea dos animais IL-4 apresentaram maior níveis de uréia sérica e maior expressão de RNAm IL-6, esses dados comprovam que realmente a citocina IL-12 parece ser a principal citocina envolvida no processo inflamatório desencadeado pela lesão de isquemia e reperfusão renal.

Tais achados favorecem a hipótese dos efeitos deletérios das células com perfil Th1 
e o papel protetor das células Th2 na lesão isquêmica renal. Estes novos episódios podem fornecer a base para uma melhor compreensão fisiopatológicos, bem como para o desenvolvimento de métodos preventivos e terapêuticos para a insuficiência renal aguda isquêmica.

Palavras-chave: Isquemia, Reperfusão, Renal, Th1, Th2, linfócitos TCD4+ e citocinas. 


\section{Abstract}

Renal ischemia/reperfusion injury $(\mathrm{I} / \mathrm{R})$ is the major cause of acute renal failure $(\mathrm{ARF})$ in the native as well as in the transplanted kidneys, with a complex pathogenesis that involves many components of inflammatory response such as leukocyte infiltration and generation of inflammatory mediators by tubular cells. Recent evidences show a critical role of the $\mathrm{CD} 4+\mathrm{T}$ cell, with the Th1/Th2 paradigm as a possible effectors mechanism. The present study has the objective to investigate the participation of some main Th1 and Th2 cytokines in the development of the renal of I/R. For that, we developed an experimental model of renal I/ $\mathrm{R}$ in deficient in IL-12, IFN- $\gamma$, double deficient IFN- $\gamma$ and IL-12 (representing defect of the pathway Th1), IL-4 and IL-10 (representing defect of the pathway Th2) and in double deficient IL-10 and IL-12 knockout mice, having wild-type mice as controls. All animals were submitted to renal I/R by reversible ligation of the renal pedicles for 45 minutes followed by 24 hours of reperfusion. After induction of the ischemia, we analyzed renal function and morphometric histological analyzes. Furthermore, we quantified the expression of HO-1 (cytoprotection gene), t-bet (transcription factor involved in the differentiation Th1), GATA-3 (transcription factor involved in the differentiation Th2), and cytokine pro-inflammatory IL-6 and chemokine pro-inflammatory MCP-1, aiming to characterize the influence of Th1/Th2 polarization in the immune response driven by the renal I/R. We showed that the IL- 4 , IFN- $\gamma$, IL-10 and IL-10/IL-12-deficient mice presented an important kidney dysfunction, characterized by higher levels serum creatinine and tubular necrosis, being comparable to the 
wild-type animals. The molecular analyses, utilizing the real-time PCR, showed a significantly higher expression of HO-1, IL-6, MCP-1 and transcription factor involved in the differentiation Th2 (GATA-3) in the in IL-4, IFN- $\gamma$, IL-10 and IL-10/IL-12-deficient mice, in comparison with the in IL-12, IFN- $\gamma /$ IL-12-deficient mice showed lower expression transcription factor involved in the differentiation Th1 (T-bet). Moreover, the renal dysfunction seen in Th2-deficient mice was followed by a higher expression of IL-6.

When we make the transfer adoptive of bone marrow of animals deficient in IL-12 and IL-4 to wild animals previously with sublethal cell depletion, these animals produce similar results to animals deficient in IL-12 and IL-4, where the animals reconstituted wild animals with bone marrow IL-12 showed lower levels of serum urea and lower expression mRNA of IL-6, while the wild animals reconstituted with bone marrow of animals IL-4 showed higher levels of serum urea and greater expression of mRNA IL-6

These data show that really the cytokine IL-12 appears to be the main cytokine involved in the inflammatory process triggered by the injury of ischemia and reperfusion kidney.

Such findings favor the hypothesis of the deleterious effects of Th1 cells with profile and the protective role of Th2 cells in ischemic renal injury. These novel insights may provide basis for the better pathophysiological understanding, as well as for development of preventive and therapeutic methods for the ischemic acute renal failure.

Key Words: Ischemia, Reperfusion, Renal, Th1, Th2, Lymphocyte TCD4 + and cytokines. 


\section{Lista de Abreviatura}

Abreviaturas utilizadas ao longo deste trabalho.

AP-1 - Proteína ativadora 1

APC - Célula apresentadora de antígeno

B7 -1/2 - Antígeno de ativação de linfócito B

CO - Monóxido de Carbono

CoPPIX - Cobalto de Protoporfirina

COX - Ciclooxigenase

CTLA-4 - Antígeno linfocitário T citotóxico 4

CXC - Quimiocinas do grupamento cisteína-aminoácido-císteína

CD-28 - Molécula co-estímulatória de linfócito T

DC - Células dendriticas

ERO - Espécies Reativas de Oxigênio

GATA-3 - Fator de Transcrição para diferenciação do perfil Th2

GK 1.5 - anticorpo anti-CD4

H2O2 - Peróxido de hidrogênio

HO-1 - Heme-oxigenase 1

HPRT - Hipoxantina-guanina fosforibosil

I/R - Isquemia e Reperfusão

ICAM-1 - Molécula de Adesão Intercelular 1

IFN- $\gamma$ - Interferon gama 
Ig - Imunoglobulina

IL - Interleucina

IP-10 - Proteína induzida pelo interferon 10

IRA - Insuficiência Renal Aguda

LFA-1 - Antígeno 1 associado a função do linfócito

MCP-1 - Proteína quimiotática de monócito-1

MHC - Complexo principal de histocompatibilidade

MIP-2 - Proteína inflamatória macrofágica 2

MPO - Mieloperoxidase

NADPH - Nicotinamida Adenina Dinucletídeo Fosfatase

NK - Células assassinas naturais

NTA - Necrose tubular Aguda

NFKB - fator Nuclear Kappa B

NKT - Células T assassinas naturais

O2 - Anion superóxido

$\mathrm{OH}$ - Íon hidroxila

PAMP - Padrões moleculares associados a patógenos

PCR - Reação de polimerização em cadeia

PRP - Receptor de reconhecimento de padrões

RAG - Proteína ativadora da recombinação

RANTES - Regulated upon activation: normal T cell expressed-secreted

STAT-4 - Fator de ativação e de transdução de sinal via Th1

STAT-6 - Fator de ativação e de transdução de sinal via Th2

SF - Soro Fisiológico

TGF- $\beta$ - Fator Transformador de Crescimento $\beta$

TLR - Toll like Receptor 
T-bet - Fator de Transcrição para diferenciação do perfil Th1 TNF- $\alpha$ - Fator de Necrose Tumoral alfa

VCAM-1 - molécula de adesão celular vascular 1 


\section{Lista de Figuras}

1.1. Diferenciação e regulação das sub-populações das células T CD4+, Th1, Th2, Th17 e diferenciação das células T reguladoras (Treg) em camundongos. Adaptado de Lawrence Steinman, Nat. Med. 13(3):385, 2007. . . . . . . . . . . . . 47

3.1. Esquema do protocólo de estudo de $I / R . \ldots \ldots$. . . . . . . . . . 54

3.2. Fotos representativas do procedimento cirúrgico (A) e do aspecto macroscópico dos rins isquemiados e reprefundidos por 24 horas (B). . . . . . . . . . 55

3.3. $1^{o}$ esquema do protocólo do estudo de transferência adotiva de células totais da médula óssea dos animais nocaute para citocinas IL-4 e IL-12 para os animais

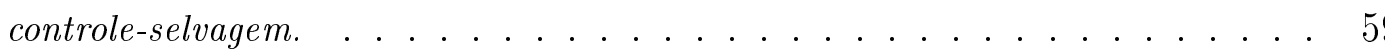

3.4. $1^{o}$ esquema do protocólo do estudo de transferência adotiva de células totais da médula óssea dos animais controle-selvagem para os animais nocautes para citocinas $I L-4$ e IL-12. . . . . . . . . . . . . . . . . . . . 60

4.1. Delta da perda de peso nos animais nocautes e nos animais selvagens submetidos somente ao procedimento cirúrgico sem ligadura do pedículo renal (Sham). Nẫo houve significância estatística entre os valores obtidos ( $A N O V A, N=3$ ), $P=0,42 . \quad 76$ 
4.2. Delta da perda de peso entre animais sham e submetidos à lesão de $I / R$ renal após 24 de reperfusão. (**) Houve significância estatística na comparação entre os animais selvagens do grupos sham e submetidos à lesão de $I / R . N=4-6$ para os grupos $I / R$ e $N=3$ para os grupos Sham. . . . . . . . . . . . 77

4.3. Função renal nos animais nocautes e nos animais selvagens sham-operados. Não houve significância estatística entre os valores obtidos (ANOVA, N=3, $p=0,41) \ldots \ldots \ldots \ldots \ldots \ldots \ldots \ldots \ldots \ldots \ldots \ldots \ldots \ldots \ldots \ldots$

4.4. Função renal após 24 horas de reperfusão nos animais nocautes para IL-4 (a),

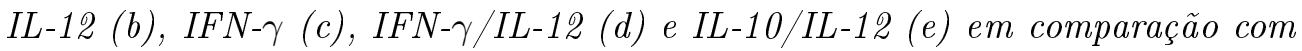
os animais selvagens. Não houve diferença estatistica entre os valores obtidos nos animais estudados ( $A N O V A, N=3$ animais sham e $N=4-6$ animais $I / R$ ). . 80

4.5. Valores médios da percentagem de necrose tubular (NT) na medula externa dos animais selvagens e nocautes submetidos a lesão de $I / R .\left(^{*}\right)\left(^{* *}\right)$ Houve significância estatística somente entre os valores encontrados nos animais selvagens e os quantificados nos animais nocautes para IL-12 e IFN- $\gamma / I L-12$, $p=0,012$. ANOVA, $N=4-6 \ldots \ldots \ldots \ldots$

4.6. Valores médios da percentagem de regeneração tubular (RT) na medula externa dos animais selvagens e os nocautes submetidos a lesão de $I / R$. Os animais nocautes IFN- $\gamma$ apresentaram maior regeneração tubular. (*) Houve diferença significativa entre os valores encontrados nos animais selvagens e os quantificados nos animais nocautes para IFN- $\gamma$. ANOVA, N=4-6. $P=0,03 . \ldots . . .82$ 
4.7. Fotos ilustrativas de corte histológico corado com HẺE, mostrando alterações compativeis com Necrose Tubular (NT) e Regeneração Tubular (RT) dos grupos dos animais Sham e submetidos à lesão de $I / R$ com 24 horas de reperfusão: Controle Sham e I/R, b) IL-12 -/-Sham e I/R, C) IFN- $/$ /L-12 -/- Sham e

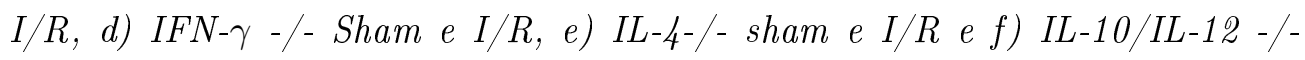
sham e $I / R$. Objetiva com aumento de $40 X . N=4-6 . \quad \ldots \ldots . . \ldots 83$

4.8. Delta da perda de peso entre animais $I L-10$ nocautes sham e submetidos à lesão de $I / R$ renal em comparação com os animais selvagens. Nâo houve diferença estatística entre os grupos ( $A N O V A, N=3$ animais Sham e $N=4-6$ animais $I / R$,

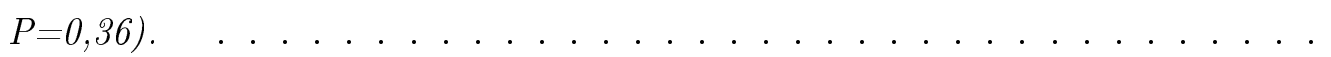

4.9. Função renal após 24 horasde reperfusão nos animais nocautes para citocina IL-10 em comparação com os animais selvagens. Não houve diferença estatística entre os valores obtidos nos animais selvagens e nos nocautes para IL-10 (ANOVA, $N=3$ animais Sham, $N=4$ animais $I / R, P=0,37)$. . . . . .

4.10. Valores médios da percentagem de Necrose Tubular (NT) na medula externa dos animais selvagens e IL-10 nocautes submetidos a lesão de $I / R$. (*) Houve diferença estatística entre os valores (T-test, $N=4-6, P=0,005) . \quad \ldots \ldots$

4.11. Valores médios da percentagem de Regeneração tubular (RT) na medula externa dos animais selvagens e nocautes para IL-10 submetidos a lesão de I/R. (*) Houve diferença estatística entre os valores obtidos (T-test. $N=34-6$ animais $I / R, P=0,003.) \ldots \ldots \ldots \ldots \ldots$

4.12. Fotos ilustrativas de corte histológico corado com HEE, mostrando alterações compativeis com Necrose Tubular (NT) e Regeneração Tubular (RT) dos grupos dos animais sham e submetidos à lesão de $I / R$ após 24 horas de reperfusão : a) Controle Sham e $I / R$ b) IL-10 -/- sham e I/R. ANOVA. Objetiva em um aumento de $40 X$. 
4.13. Expressão do gene T-bet nos rins dos animais selvagens e nos nocautes de IL-

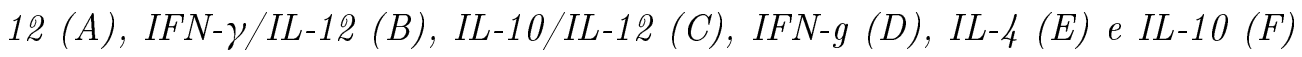
após 24 horas de reperfusão. (*) Houve significância estatística entre os valores obtidos nos animais selvagens e nos nocautes para IL-4, IL-10/IL-12 e IFN- $\gamma$. T-test,$N=4-6 \ldots \ldots \ldots \ldots \ldots \ldots$

4.14. Expressão do gene GATA-3 nos rins dos animais selvagens e nos nocautes de

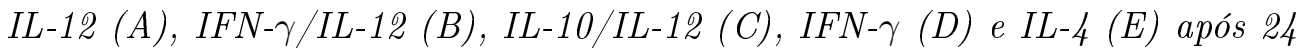
horas de reperfusão. (*) Houve significância estatística entre os valores obtidos nos animais selvagens e nos nocautes para IL-4, IL-12, IL-10/IL-12, IL-10 e

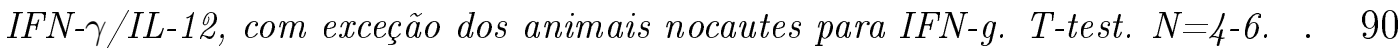

4.15. Expressão do gene MCP-1 nos rins dos animais selvagens e nos nocautes de

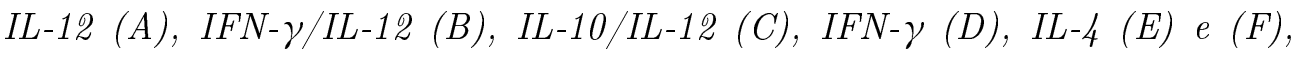
IL-10 após 24 horas de reperfusão. ( *) Houve significância estatística entre os valores obtidos nos animais selvagens e nos nocautes IFN- $\gamma$ e duplo-nocautes IL-10/IL-12. T-test. $N=4-6 \ldots \ldots \ldots \ldots \ldots \ldots$

4.16. Expressão do gene $I L-6$ nos rins dos animais selvagens e nos nocautes de $I L$ -

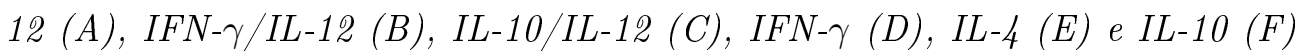
após 24 horas de reperfusão. (*) Houve significância estatística entre os valores obtidos nos animais selvagens e nos nocautes para IL-12 . T-test. $N=4$-6. . . .

4.17. Expressão do gene HO-1 nos rins dos animais selvagens e nos nocautes de IL-

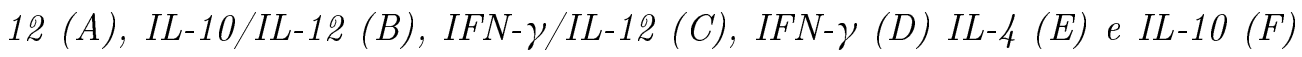
após 24 horas de reperfusão. Não houve significância estatística entre os valores obtidos nos animais selvagens e nocautes estudados. T-test. $N=4-6 . \ldots . .$.

4.18. Correlação entre os valores logaritimizados da expressão do RNAm dos genes IL-6 e da HO-1 em todos os animais de todos os grupos estudados. Houve significância estatístisca, com $p<0,0001$. 
4.19. Análise fenotípica dos linfócitos $(C D 3+, C D 4+e$ CD8+) de baço de animais irradiados por fonte de cobalto após 24 horas da irradiação. As células foram marcadas com anticorpos monoclonais fluorescentes e analisadas através de Citometria de Fluxo (FACS), confirmando a depleção celular da medula desses

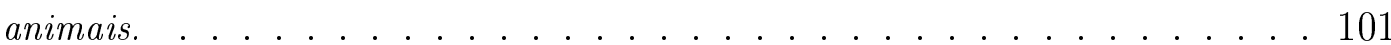

4.20. Análise fenotípica dos linfócitos (CD3+, CD4 + e CD8+) de baço de animais irradiados por fonte de cobalto após 24 horas da irradiação e que sofreram transferência adotiva de células totais de médula óssea (20 x 106 células totais de M.O) e que permaneceram durante 6 semanas reconstituindo a medula. As células foram marcadas com anticorpos monoclonais fluorescentes e analisadas através de Citometria de Fluxo (FACS), confirmando a reconstituição celular da medula desses animais. . . . . . . . . . . . . . . . . 102

4.21. Delta da perda de peso entre animais nocautes $I L-12$ reconstituído com células totais da medula óssea e sham e submetidos à lesão de $I / R$ renal em comparação com os animais selvagens que também receberam transferência adotiva de células totais da medula óssea. Nâo houve diferença estatística entre os grupos. ANOVA, N=4.WT- Controle selvagem- C57BL/6. . . . . . . . 103

4.22. Delta da perda de peso entre animais nocautes IL-4 reconstituído com células totais da medula óssea e sham e submetidos à lesão de IR renal em comparação com os animais selvagens que também receberam transferência adotiva de células totais da medua óssea. Não houve diferença estatítica entre os grupos. ANOVA, N=3. WT- controle selvagem - C57BL/6. . . . . . . . 104 
4.23. Função renal após 24 horas de reperfusão nos animais selvagens reconstituídos com células totais da medula óssea de animais nocautes IL-12 (a), IL-12 -/- $\rightarrow$ $W T(b), W T \rightarrow I L-12-/-.\left(^{*}\right)$ Houve diferença estatística entre os valores obtidos nos animais IL-12 - /- $\rightarrow$ WT. ANOVA, N=4. WT- controle selvagem-

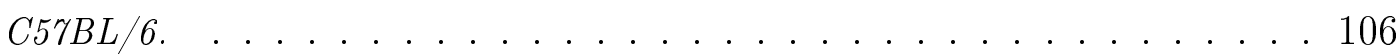

4.24. Função renal após 24 horas de reperfusão nos animais selvagens reconstituídos com células totais da medula óssea de animais nocaute IL-4 (a), IL-4 -/- $\rightarrow$

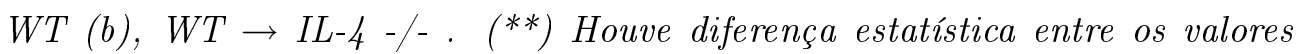
obtidos nos animais IL-4 -/- $\rightarrow$ WT. ANOVA, N=4. WT- controle selvagem

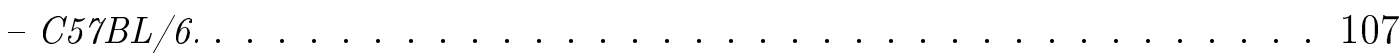

4.25. Expressão do gene IL-6 nos rins dos animais selvagens quiméricos e nos animais IL-12 quiméricos (A), IL-12-/- $\rightarrow W T(B), W T \rightarrow I L-12-/-$ após 24 horas de reperfusão. Houve significância estatística entre os valores obtidos nos animais $W T \rightarrow I L-12-/$-. ANOVA, N=4,WT-controle selvagem - C57BL/6. . . 109

4.26. Expressão do gene IL-6 nos rins dos animais selvagens quiméricos e nos animais IL-4quiméricos (A), IL-4-/- $\rightarrow$ WT (B), WT $\rightarrow I L-4-/-$ após 24 horas de reperfusão. Não houve significância estatística entre todos os grupos. ANOVA, $N=4 . W T$ - controle selvagem $-C 5 B L / 6$. . . . . . . . . . 110

4.27. Valores médios da percentagem de necrose tubular (NT) na medula externa dos animais selvagens quiméricos e nocautes IL-4 quiméricos submetidos a lesão de $I / R$ com 24 horas de reperfusão. (*) Houve significância estatística entre todos os grupos. ANOVA, N=4.WT-Controle Selvagem-C57BL/6. ..... 111

4.28. Valores médios da percentagem de necrose tubular (NT) na medula externa dos animais selvagens quiméricos e nocautes IL-12 quiméricos submetidos a lesão de $I / R$ com 24 horas de reperfusão. (*) Houve significância estatística entre todos os grupos. ANOVA, N=4. WT - Controle Selvagem - C57BL/6. . . 111 
4.29. Valores médios da percentagem de Regeneração tubular (RT) na medula externa dos animais selvagens quiméricos e nocaute IL-12 quiméricos submetidos a lesão de $I / R$ com 24 horas de reperfusão. (*) Houve significância estatística entre todos os grupos. ANOVA, $N=4-W T-$ Controle Selvagem $-C 57 B L / 6 . \quad \ldots 112$

4.30. Valores médios da percentagem de Regeneração tubular (RT) na medula externa dos animais selvagens quiméricos e nocautes IL-4 quiméricos submetidos a lesão de $I / R$ com 24 horas de reperfusão. (**) Houve significância estatística entre todos os grupos. ANOVA, N=4-WT-Controle Selvagem - C57BL/6. . . 113

4.31. Fotos ilustrativas de corte histológicos corado com HẺE mostrando alterações compativeis com Necrose Tubular (NT) e Regeneração Tubular (RT) dos grupos dos animais quiméricos e submetidos à lesão de $I / R$ com 24 horas de reperfusão: a) controle, b) IL-12 -/- $\rightarrow$ WT sham e $I / R, C) W T \rightarrow I L-12-/-$ Sham e $I / R$ ,d) IL-4-/- $\rightarrow W T$, e) $W T \rightarrow I L-4-/-$ Sham e I/R. ANOVA, N=3. Objetiva com aumento de $40 X . \ldots \ldots \ldots . \ldots . \ldots 114$ 


\section{Lista de Tabelas}

3.1. Sequência (sense/antisense) e concentração dos "primers" utilizados no estudo na reação de Real Time PCR. .................... 66

3.2. Reações (em triplicatas) de Real Time PCR com SyBr Green PCR Master Mix

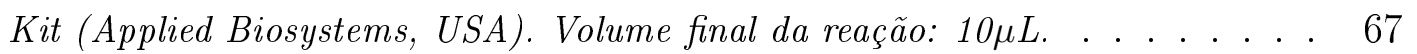

3.3. Temperaturas e tempos utilizados nas fases sequênciais do Real Time PCR. • . 68

4.1. Concentração (Pg/mL de citocinas e quimiocinas pró-inflamatórias (KC e IL6) no soro de camundongos nocautes ou controle-selvagem. $N=3 . N D=N a \tilde{o}$ Determinado $;+=$ Presença. . . . . . . . . . . . . . . . 97 


\section{Sumário}

1. Introdução 30

1.1. Lesão de Isquemia e Reperfusão Renal . . . . . . . . . . . . . . . . . . 31

1.2. Lesão de Isquemia e Reperfusão como um Processo Inflamatório . . . . . 32

1.2.1. Inflamação . . . . . . . . . . . . . . . 32

1.3. A lesão de Isquemia e Reperfusão e a Resposta Imune Inata . . . . . . . 34

1.4. A lesão de Isquemia e Reperfusão e a Resposta Imune Adaptativa . . . . 38

1.5. Resposta imune adaptativa de padrão Th1 . . . . . . . . . . . . . . 41

1.6. Resposta imune adaptativa de padrão Th2 . . . . . . . . . . . . . . . . 44

1.7. Principais Fatores Transcricionais Envolvidos na Polarização Th1/Th2 45

1.8. Participação citocinas e dos fatores transcricionais relacionados a diferenciação dos padrões Th1 e Th2 na lesão de Isquemia e Reperfusão . . . . . 46

1.9. Heme-oxigenase e lesão de I/R . . . . . . . . . . . . . . 47

2. Objetivos 50

3. Materiais e Métodos 52

3.1. Modelo Experimental Isquemia e Reperfusão Renal . . . . . . . . . . . 53

3.2. Grupos Experimentais . . . . . . . . . . . . . 55

3.3. Modelo Experimental de Transferência Adotiva de Medula Óssea . . . . . 56

3.4. Os animais foram agrupados da seguinte forma . . . . . . . . 57 
3.5. Parâmetros Estudados . . . . . . . . . . . . . 58

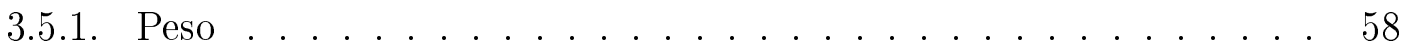

3.5.2. Função renal Creatinina . . . . . . . . . . . . . . . 61

3.5.3. Uréia ........................... 61

3.6. Análise Histomorfométrica . . . . . . . . . . . . . . . 62

3.7. Análise dos Transcritos Gênicos . . . . . . . . . . . . 63

3.7.1. Amostras para biologia molecular . . . . . . . . . . . 63

3.7.2. Obtenção de fragmentos Renais . . . . . . . . . . . . . . . . 64

3.7.3. Extração e purificação de RNA total - método TRIzol . . . . . . . 64

3.7.4. Síntese do DNA complementar (cDNA) . . . . . . . . 65

3.7.5. Síntese dos "primers" . . . . . . . . . . . . . 66

3.7.6. Reação de Real Time - PCR . . . . . . . . . . . . . . . . 67

3.8. Geração do Controle Positivo . . . . . . . . . . . . . 68

3.9. Genotipagem das diferentes linhagens de camundongos . . . . . . . 69

3.9.1. Citometria de Fluxo para verificação da depleção e reconstitutição dos animais com transferência adotiva de medula óssea . . . . . 70

3.10. Ensaio Bioplex . . . . . . . . . . . . . . 71

3.11. Análise Estatística . . . . . . . . . . . . . 73

$\begin{array}{ll}\text { 4. Resultados } & 74\end{array}$

I. Resultados dos estudos com animais nocautes para as citocinas do perfil Th1 (IL-12, IFN- $\gamma$ e IFN- $\gamma /$ IL-12), do perfil Th2 (IL-4 e IL-10) e para a IL-10/IL-12 75

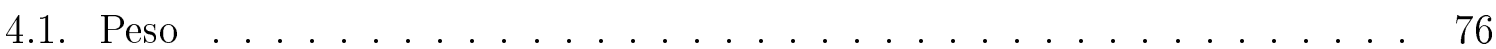

4.2. Função renal . . . . . . . . . . . . . . . . . . . . 78 
4.3. Análise morfométrica: Necrose Tubular (NT) e Regeneração tubular (RT) 81

4.4. Resultados animais nocaute para citocina IL10 . . . . . . . . . . . 83

4.5. Análises dos transcritos gênicos . . . . . . . . . . . . . 87

4.5.1. Transcrito gênico: T-bet . . . . . . . . . . . . . . 88

4.5.2. Transcrito Gênico: GATA-3 . . . . . . . . . . . . . 89

4.5.3. Transcrito Gênico: MCP-1 . . . . . . . . . . . . . . 91

4.5.4. Transcrito Gênico: IL-6 . . . . . . . . . . . . . . . . 92

4.5.5. Transcrito Gênico: HO-1 . . . . . . . . . . . . . . . 94

4.6. Correlação entre os valores do RNAm de IL-6 e HO-1 em todos os animais de todos os grupos estudados . . . . . . . . . . . . . . 95

4.7. Resultados Bioplex . . . . . . . . . . . . . . . 96

4.7.1. IL-6 . . . . . . . . . . . . . . . 96

4.7.2. IL $4 \ldots \ldots \ldots \ldots \ldots \ldots \ldots \ldots$

$4.7 .3 . \mathrm{KC} \ldots \ldots \ldots \ldots \ldots \ldots$

\section{Resultados dos grupos dos animais quimeras 99}

4.8. Caracterização dos esplenócitos de camundongos irradiados antes de receber a transferência adotiva de células totais da medula óssea . . . . . 100

4.9. Caracterização dos esplenócitos nos camundongos irradiados após 6 semanas do recebimento da transferência adotiva de células totais da medula óssea . . . . . . . . . . . . . . . . . . . . 101

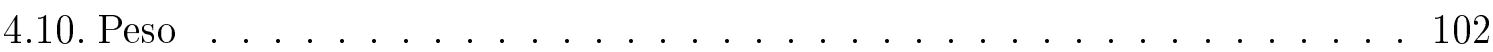

4.10.1. Peso dos grupos dos animais nocaute para citocina IL-12 quimérico 102 4.10.2. Peso dos grupos dos animais nocaute para citocina IL-4 quimérico 103 4.11. Função Renal . . . . . . . . . . . . . . . . . . . . . . . . 104 4.12. Função renal dos grupos dos animais nocaute para citocina IL-12 . 105 
4.13. Função renal dos grupos dos animais nocaute para citocina IL-4 . . . . . 106

4.14. Análise do RNA mensageiro de IL-6 . . . . . . . . . . . . . 108 4.14.1. Expressão de IL-6 nos grupos dos animais nocautes para citocina IL-12 quiméricos . . . . . . . . . . . . . . 108 4.14.2. Expressão de IL-6 nos grupos dos animais nocautes para citocina IL-4 quiméricos . . . . . . . . . . . . . . . . 109 4.15. Análise morfométrica: Necrose Tubular (NT) e Regeneração tubular (RT) 110

5. Discussão

6. Considerações Finais 131

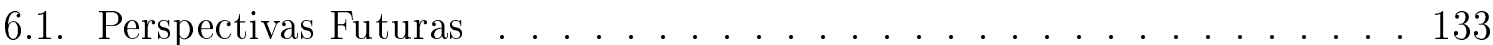

7. Conclusões 136

Referências Bibliográficas 
1. Introdução 


\subsection{Lesão de Isquemia e Reperfusão Renal}

A lesão de Isquemia e Reperfusão (I/R) renal [1] é uma causa comum da falência renal aguda (Insuficiência Renal Aguda, IRA). A I/R é a maior causa de IRA em rins transplantados e nativos [1]. Atualmente não se conhece nenhum tratamento para essa doença [2], por isso é importante um melhor entendimento de sua fisiopatologia. Nos últimos anos a Sociedade Americana de Nefrologia redefiniu o conceito de IRA (Acute Kidney Injury Network, AKIN, ASN). Assim, hoje, instituiu-se o termo Lesão Renal Aguda (LRA) para definir uma entidade que apresenta inúmeros estágios de lesão tecidual, sendo o último associado com perda da função renal, a IRA.

Nos últimos anos, a Sociedade Americana de Nefrologia redefiniu o conceito de IRA (Acute Kidney Injury Network, AKIN, ASN). Assim, hoje, instituiu-se o termo Lesão Renal Aguda (LRA) para definir uma entidade que apresenta inúmeros estágios de lesão tecidual, sendo o último associado à perda da função renal, a IRA.

A IRA acomete cerca de 5\% de todos os pacientes hospitalizados, estando associada a uma taxa de mortalidade superior a $50 \%$ nos que requerem tratamento dialítico, apesar dos recentes avanços nas medidas terapêuticas de prevenção e de suporte clínico [3, 4], inalterada nas últimas décadas [5]. Em um estudo de 1997, apenas 27\% dos pacientes com IRA estavam vivos após 5 meses. Além disso, eles permaneciam com numerosas limitações funcionais e o custo do procedimento era extremamente alto [6].

Da mesma forma, os enxertos renais que evoluem com Necrose Tubular Aguda (NTA) após o transplante também apresentam sobrevida reduzida quando comparados com os enxertos que funcionam imediatamente [7].

Experimentalmente, a lesão I/R renal pode ser estudada através da obstrução dos pedículos renais. A isquemia é definida como a falta de oxigênio e nutrientes para determinadas áreas dos tecidos por um período de tempo [8]. Após o retorno do fluxo sangüíneo para o parênquima renal, isto é, a reperfusão, ocorre o desencadeamento 
de um conjunto de eventos fisiopatológicos, caracterizados pela produção de Espécie Reativa de Oxigênio (ERO), infiltração de células inflamatórias, produção de citocinas pró-inflamatórias e quimiocinas [9].

A inflamação tem papel central na patogenia da lesão de I/R [10]. Inicialmente, neutrófilos, macrófagos e as moléculas de adesão foram vistos como os principais mediadores da inflamação tecidual, sendo, portanto, o maior foco de pesquisa. Contudo, atualmente, tem-se dado muita importância ao envolvimento de outros componentes da resposta imune inata, assim como da resposta imune adquirida na lesão de $\mathrm{I} / \mathrm{R}$ renal.

\subsection{Lesão de Isquemia e Reperfusão como um Processo Inflamatório}

\subsubsection{Inflamação}

São crescentes as evidências de que a IRA é uma doença inflamatória, destacando-se as contribuições da lesão endotelial, a infiltração leucocitária e a geração de mediadores inflamatórios pelas células tubulares [11]. Muitos fatores que atuam na cascata da inflamação estão presentes logo após o evento da isquemia. E esses processos ainda são exacerbados pela reperfusão [12]. Inicialmente, a lesão de I/R leva a uma disfunção e a uma ativação das células endoteliais, implicando uma desregulação no tônus da vasculatura e, conseqüentemente, no aumento da permeabilidade capilar. Os leucócitos são ativados e passam a expressar moléculas de adesão como, por exemplo, as selectinas, que são responsáveis pelo rolamento inicial, e as integrinas, em sua conformação ativa (LFA-1, CD11a/CD18), diminuindo o fluxo sangüíneo microvascular, principalmente na região da medula externa em relação ao córtex renal [13, 14]. O grupo do Professor Hamid Rabb e seus colaboradores demonstrou que animais deficientes em L-selectina (CD62L) eram protegidos da I/R renal, apresentando menores danos renais, baixos níveis 
de creatinina e uréia e um menor infiltrado de neutrófilos quando comparados com os animais selvagens [15]. Tilney e colaboradores também estudaram a participação da L-selectina na lesão de I/R. Ratos tratados com anticorpos anti-selectinas e submetidos à lesão de $\mathrm{I} / \mathrm{R}$ tiveram menor dano tecidual renal analisado por histologia e menor expressão de IL-6, TNF- $\alpha$ e TGF- $\beta$ quando comparados com animais selvagens [16].

Vários investigadores demonstraram a importância da molécula ICAM-1 (CD54), ligante do LFA-1, na lesão renal isquêmica. Em animais, foi demonstrado que a administração de um anticorpo anti-ICAM-1 era protetora. Além disso, camundongos nocaute para ICAM-1 eram protegidos da lesão por I/R [17]. Mais ainda, outros estudos mostraram que a diminuição ou inibição da expressão de ICAM-1 [18, 19] e de selectinas através do aumento de expressão de IL-10 ou por uso de drogas estava associada a um aumento do fluxo sangüíneo renal pós-isquêmico, o que é uma proteção para o órgão [20, 21].

Nesse processo inflamatório, as fosfolipases, especialmente a fosfolipases A2, são ativadas pela lesão de I/R. Sua ação sobre fosfolípides resulta na geração de ácidos graxos, como ácido aracdônico e lisofosfolípides. Kelly e colaboradores foram os primeiros a demonstrar que a ação das lipoxigenases e ciclooxigenases (COX) modulava a resposta inflamatória vista nos tecidos isquêmicos e ainda produzia ERO [22]. Nosso grupo demonstrou que o bloqueio das $\operatorname{COX} 1 / 2$ com endometacina tem ação protetora na lesão de I/R renal, uma vez que camundongos tratados previamente com endometacina e submetidos durante 45 minutos à lesão de I/R e após 24, 48, 72 e 120 horas de reperfusão apresentaram baixos níveis de uréia sérica e menor percentagem de necrose tubular aguda quando comparados com os animais-controle [23]. Muitos trabalhos não vêm somente enfatizando a participação das COX 1/2 na lesão de I/R renal, mas também a participação da lipoxigenase (LOX-5). Matsuyama e colegas demonstraram que COX 1/2 e LOX estava sendo altamente expresso nos rins desses ratos isquemiados após 
diferentes tempos de reperfusão [24].

Recentemente, nosso grupo, dando continuidade aos estudos com COX, demonstrou que a inibição da COX $1 / 2$ com indometacina no modelo de fibrose renal ocasionava uma diminuição da inflamação renal. Os animais tratados com indometacina e submetidos à isquemia unilateral apresentaram baixa expressão de TNF-alpha, IL-1 beta e MCP-1. Esses animais também apresentaram menor grau de fibose renal quando comparados com os animais controles sem tratamento, demonstrando o papel da COXs na lesão de I/R renal em modelo renal agudo e crônico [25].

Após reperfusão, os altos níveis teciduais de O2 não podem ser usados prontamente pela mitocôndria, ficando disponíveis, como substrato, para enzimas oxidativas, como, por exemplo, a NADPH (Nicotinamida Adenina Dinucleotídeo Fosfatase), para gerar ERO: íons hidroxila $\left(\mathrm{OH}^{-}\right)$, anions superóxido $\left(\mathrm{O}^{-2}\right)$ e peróxido de hidrogênio $\left(\mathrm{H}_{2} \mathrm{O}_{2}\right)$ [26]. As ERO promovem também a expressão de uma série de genes pró-inflamatórios associados com ativação de células endoteliais, como, por exemplo, a endotelina, citocinas, quimiocinas para monócitos e moléculas de adesão, entre outros [27].

\subsection{A lesão de Isquemia e Reperfusão e a Resposta Imune Inata}

A resposta imune inata é um dos fatores iniciais que estão envolvidos com a lesão de I/R. Os neutrófilos apresentam um papel importante na lesão de I/R, uma vez que são identificados rapidamente no tecido renal isquêmico, na região medular e na "vasa recta" [28, 29] e são também encontrados em biópsias de pacientes com IRA.

A ação dos neutrófilos na lesão de I/R pode ser feita de forma indireta, via mudanças fenotípicas em outras células, como as endoteliais, ocasionando um aumento de expressão de moléculas de adesão, tais como ICAM-1 (CD54), VCAM (CD106) e se- 
lectinas (CD62). Além dos neutrófilos, tem-se dado muita importância ao estudo de macrófagos na lesão de I/R. Os macrófagos estão relacionados à fase extensora da lesão renal, através da produção de citocinas como IFN- $\gamma$, promovendo uma inflamação persistente, glomerular e túbulo-intersticial. Além disso, os macrófagos não estão somente envolvidos com a lesão, mas também com a resolução da injúria [30].

Recentemente, foi demonstrado que as células NKT participam da lesão de I/R. Huang e colaboradores demonstraram que animais depletados de células NKT ou nocautes para NKT apresentavam uma diminuição significante de infiltração de neutrófilos, uma menor disfunção renal e uma menor produção de IFN- $\gamma$ quando analisados por citometria de fluxo em modelo de lesão de I/R renal [31].

Finalmente, existem dados na literatura mostrando o papel das células dendríticas (CD) na lesão de I/R. Trabalho recente demonstrou, através de experimentos in vitro, que as $\mathrm{CD}$ de rins de animais obtidos após a lesão de I/R e mantidas em cultura produziam citocinas pró-inflamatórias, como IL-6 e TNF- $\alpha$, e outros mediadores inflamatórios, como MCP-1 (Proteína quimiotática de monócitos), RANTES (Regulated upon Activation of Normal T Cell Expressed and Secreted). Além disso, as CD foram encontradas em algumas regiões do rim, entre o epitélio tubular e os capilares peri-tubulares [32]. Wu e colegas identificaram uma alta expressão de moléculas CD11c, CD80, CD86 e MHC II no rim de animais submetidos à lesão de I/R, 2 a 14 dias após a reperfusão [33].

A lesão de I/R é um potente indutor da ativação do sistema complemento e isso resulta na produção de mediadores inflamatórios. O uso específico de inibidores do complemento levou a uma prevenção da lesão de I/R em estudos experimentais e clínicos $[34,35]$. Wuding e colaboradores demonstraram que animais nocautes para moléculas C3, C5 e C6 apresentaram-se protegidos da lesão de I/R, quando analisado a histologia e o infiltrado de neutrófilos pela dosagem de MPO [35]. Nos animais deficientes para a 
molécula C6, o bloqueio adicional da molécula C5a conferia uma proteção renal ainda maior [35]. Outro estudo demonstrou que a inibição da molécula C5 levava a uma proteção do dano renal isquêmico, com menores taxas de apoptose e menor infiltração celular [36].

A ativação dos TLR (Toll-like receptor) induz a secreção de citocinas, quimiocinas e ao aumento na expressão de proteínas de adesão e de co-estimulação, através de sinalização que leva à ativação de fatores transcricionais, como o NF-kB (fator nuclearkappa B) e o AP-1 (proteína ativadora-1) [37]. O perfil de produção de citocinas e do infiltrado inflamatório após a reperfusão é muito parecido com aqueles observados quando o sistema imune inato é ativado pelos PAMP (Padrões moleculares associados a patógenos) via TLR [38]. Usando técnicas de real time RT-PCR, Huiling et al analisaram os níveis de expressão de IL-1 $\beta$, IL-6, MCP-1 e TNF- $\alpha$ em animais nocautes para TLR-4 e Myd88 e em animais selvagens submetidos à lesão de I/R. Observaram que esses animais nocautes eram protegidos quando comparados com o animal controle, pois apresentavam uma menor expressão de todos estes transcritos gênicos. Na análise por imunohistoquímica para infiltração de macrófagos, esses animais nocautes apresentavam também um menor infiltrado. Jaklien e colegas observaram uma menor expressão de MIP-2, MCP-1 e IL-6 nas células tubulares renais de animais nocautes para TLR-2 submetidos à lesão de I/R [39]. Todos estes dados sugerem que os receptores TLR estão envolvidos diretamente com a lesão de I/R, induzindo a produção de quimiocinas e citocinas, amplificando assim a resposta inflamatória.

Recentemente também descobriu-se um novo receptor citosólico que reconhece PAMP (Padrões Moleculares associados à Patógenos), chamado NOD- like receptors (NLRs - NOD1 e NOD2). Sua principal função é fazer uma ligação entre a resposta imune inata e adaptativa. Esse receptor contribui para processos inflamatórios e é expresso em células dendríticas, células epiteliais, monócitos/macrófagos e linfócitos T, 
levando à ativação do fator NF-KB e, assim, induzindo a produção de citocinas próinflamatórias, como IL-1 beta e IL-1 alpha. A literatura demonstra que camundongo nocaute para o receptor NOD2 -/- apresentava-se protegido da lesão hepática aguda induzida pela concanavalina A [40]. Contudo, ainda são necessários maiores estudos com esse novo receptor citosólico NOD na lesão de I/R renal.

As quimiocinas participam do recrutamento de leucócitos para o local inflamado e da regulação das células Th1/Th2. Dessa maneira, esses mecanismos podem ter um importante papel na lesão de I/R renal. Estudos com animais nocautes para CXCR3 demonstraram que eles eram protegidos após a lesão de $\mathrm{I} / \mathrm{R}$ renal quando comparados com os animais controles. No entanto, quando era feita a transferência adotiva de linfócitos T CD3+ de animais selvagens, a injúria renal era restaurada [41]. Em outro trabalho, o bloqueio do receptor CXCR2 prevenia a infiltração de granulócitos e preservava a função renal e enxertos isogênicos em ratos [42].

Um outro estudo, recentemente publicado, com camundongos nocaute para CCR2 -/- demonstrou que, após 3 horas da lesão de I/R renal, esses animais apresentaram níveis menores de creatinina sérica e infiltrado menor de macrófago, ou seja, esses animais foram protegidos da lesão de I/R. Quando se gerou um animal quimera que recebeu medula óssea do animal nocaute para CCR2-/-, esses animais continuaram sendo protegidos da lesão de I/R, pois apresentaram níveis menores de creatinina sérica, um menor infiltrado de macrófago e uma menor produção de TNF-alpha, IL-1 alpha, IL-12 e IL-6 pelos monócitos presentes nos rins desses animais [43]. 


\subsection{A lesão de Isquemia e Reperfusão e a Resposta Imune Adaptativa}

Os linfócitos T são responsáveis por reações imunológicas específicas, pois são as únicas células do sistema imune capazes de reconhecer diferentes determinantes antigênicos. Os linfócitos T são subdivididos em duas populações distintas, que expressam diferentes proteínas de membrana: linfócito T CD4+ (T auxiliador) e o linfócito T CD $8+(\mathrm{T}$ citotóxico). Os linfócitos reconhecem peptídeos antigênicos apenas quando associados às moléculas MHC de classe II e I (complexo principal de histocompatibilidade), respectivamente, e expressos na superfície de células apresentadoras de antígenos (APC). Em resposta à estimulação antigênica, o linfócito T CD4 + secreta citocinas que promovem proliferação e diferenciação de células T e de outras células, incluindo linfócito B e macrófagos [44].

Nos últimos anos, têm-se estudado muito a participação dos linfócitos na lesão de I/R. O primeiro e o mais importante grupo que descreveu a participação dos linfócitos T na lesão de I/R foi o grupo do Professor Hamid Rabb e colaboradores, no qual eles demonstraram que animais nocautes para moléculas CD4 e CD8 eram protegidos da isquemia, pois apresentavam baixos níveis de creatinina e menores índices de lesão tubular quando comparados com animais controles. Além disso, quando eles reconstituíram os animais com as populações de linfócitos T CD4+ e CD8+, os animais apresentaram uma lesão renal semelhante aos controles selvagens, demonstrando que os linfócitos estão envolvidos na lesão de I/R renal [45]. Esse mesmo grupo ainda utilizou animais selvagens, fazendo timectomia e tratando-os com anticorpo anti-CD4 (GK 1.5). Conseqüentemente, os animais apresentavam menor lesão renal e menor infiltrado de neutrófilos após a lesão de I/R. Estes dados foram comprovados por um estudo realizado no nosso grupo por Pinheiro e colaboradores [46].

Vanessa N. de Paiva 
A participação das células B na lesão renal pela I/R também vem sendo largamente estudada por meio da observação de proteção do dano renal em camundongos deficientes em células B submetidos à isquemia [47]. Corroborando isso, a transferência de soro de camundongos normais para camundongos deficientes em células B restaura a lesão, favorecendo a possível participação de um produto solúvel, como um anticorpo, neste processo, consistente com o achado de maior susceptibilidade de IRA em pacientes com mieloma múltiplo que apresentam altos níveis de anticorpos circulantes [1].

Evidência experimental recente, utilizando camundongos deficientes do gene RAG1 (recombination-activating gene-1), fundamental para a recombinação dos receptores BCR e TCR, mostrou que, enquanto a deficiência isolada de células B ou células T reduzia a lesão renal pela I/R, a deficiência combinada dos dois tipos de células não era protetora, demonstrando que interações complexas entre as imunidades inata e adaptativa são importantes na determinação da agressão renal isquêmica [48]. Mas esses dados ainda são muito controversos, pois outros trabalhos na literatura demonstram que animais deficientes do gene RAG-1 são protegidos da lesão de I/R renal, mas quando esses animais são submetidos à transferência adotiva de linfócitos T CD4+ a lesão renal é restaurada, o que mostra a necessidade de mais estudos para demonstrar qual a verdadeira função do gen RAG-1 na lesão de I/R renal [49].

E os linfócitos T não convencionais, que são as células T que possuem as cadeias gama-delta $(\gamma \delta)$ de seus receptores, são uma população menor, tanto nos órgãos linfóides quanto na circulação, mas são proeminentes na pele, nos intestinos e nos pulmões [50]. Essas células são capazes de modular a produção de citocinas por células NK [51], estabelecendo uma importante interação entre as respostas inata e a adaptativa. Na literatura, também já foi demonstrado o papel desses linfócitos na lesão de $\mathrm{I} / \mathrm{R}$ renal. $\mathrm{O}$ grupo do professor Hamid Rabb e colaboradores também estudou a participação desses linfócitos $\mathrm{T} \gamma \delta$ na lesão I/R, utilizando animais deficientes para as cadeias $\gamma \delta$ e $\alpha \beta$. Após 
a lesão de I/R, os níveis de creatinina se apresentaram baixos e a análise por histologia demonstrou menor dano renal quando comparados com os animais controles. Além disso, a produção de IL-6, IL-1 $\beta$, IL-2, IFN- $\gamma$, TNF- $\alpha$ e RANTES foi menor nestes animais quando comparados com os animais selvagens. Isso nos leva a pensar que a ativação do linfócito via TCR seja relevante na lesão de $\mathrm{I} / \mathrm{R}$, contribuindo com a produção de citocinas pró-inflamatórias [52].

O último trabalho publicado em 2008 pelo grupo do professor Hamid Rabb mostrou a caracterização do repertório de linfócitos T presentes no rim de camundongos normais e isquemiados, comparando com a presença de células $\mathrm{T}$ em outros órgãos como baço, fígado, pulmão e no sangue. Observou-se que há no rim a presença de um grande de linfócitos $\mathrm{T}$, como os linfócito T CD4+, CD $8+$ e LB, há também a presença de populações duplo negativas e duplo positiva DP (DN - CD3+CD4-CD8- e DP - CD3+CD4+CD8+), populações TCR cadeia $V \beta$ semelhantes a encontrada em outros órgãos nos animais normais e isquemiados. Outra população celular encontrada no rim desses animais foi a NKT, por meio da análise por citometria de fluxo por marcação das populações celulares NK1.1 e CD1d [53]. De forma interessante, o grupo do professor Rabb identificou a presença, no rim desses animais normais e isquemiados, de uma população celular de células T regulatórias chamada Treg, que tem, como principais marcadores de superfície, populações celulares CD4 + CD25 + e o fator transcricional Foxp3 $+(\mathrm{CD} 4+\mathrm{CD} 25+$ Foxp3 +$)$. As células T regulatórias estão associadas ao controle da autoimunidade e são responsaveis pela manutenção da tolerância. Com o controle da resposta imune, evidências experimentais sugeriam que, em diversos modelos animais, a remoção ou a inativação dessa população de células T poderia quebrar a auto-tolerância natural do organismo e levar ao desenvolvimento de diversas doenças auto-imunes. Sendo assim, esses resultados sugerem que o rim também pode modular a resposta imune durante um processo inflamatório desencadeado pela lesão de I/R renal [53, 54]. 
A ativação de células $T$ requer duas classes de sinais: um desencadeado pelo receptor propriamente dito (receptor de célula T - TCR) e outro "acessório" ou coestimulatório. Se apenas o estímulo via TCR acontece, não há resposta ativa. A via co-estimulatória mais bem entendida é a via das moléculas B7-1 e B7-2, presentes nas células APC. Elas interagem com a molécula CD28 e CTLA-4 (cytotoxic T lymphocyte antigen) de células T. A lesão de I/R induz a liberação de TNF- $\alpha$ e de outras citocinas que induz a expressão de B7 no rim isquêmico e, desta forma, pode facilitar a ativação efetiva da célula $\mathrm{T}$ frente a um antígeno. Takada e cols. mostraram, num modelo de isquemia renal em ratos, aumento na expressão de B7-1 e que seu bloqueio através de CTLA4-Ig promovia diminuição do infiltrado de células T e de macrófagos, uma diminuição na secreção de citocinas, de quimiocinas e de fatores de crescimento. A proteção contra os efeitos da lesão de I/R pode ter sido mediada tanto pelo bloqueio da ativação dos linfócitos, decorrente do bloqueio do seu co-estímulo, como pelo bloqueio da interação entre a célula $\mathrm{T}$ e a célula endotelial que, impedindo o fluxo de células inflamatórias (macrófagos e linfócitos T CD4+) e das substâncias produzidos por eles, melhoraram de forma significativa a lesão tecidual [16].

\subsection{Resposta imune adaptativa de padrão Th1}

A principal citocina envolvida para polarização do perfil Th1 é a IL-12. A IL-12 é produzida principalmente pelas CD, macrófagos e por monócito do sangue periférico [55] em resposta a produtos microbianos, como LPS, por meio da sinalização via TLR-4 [56].

Estruturalmente, a IL-12 é um heterodímero formado por uma cadeia leve de 35 kDa (p35 ou IL-12 $\alpha$ ) e uma cadeia pesada de $40 \mathrm{kDa}(\mathrm{p} 40$ ou IL-12 $\beta$ ) [57]. O receptor da IL-12 (IL-12 R) também é formado por duas cadeias (IL-12R $\beta 1$ e IL-12R $\beta$ ) e a ligação da IL-12 ao seu receptor faz com que membros da família da Janus-quinase (JAK2-TYK2) 
ativem-se. A fosforilação do receptor de IL-12 forma um sítio de ligação para a proteína STAT. Assim, a IL-12 pode ativar tanto o STAT-1 quanto o STAT-3 e o STAT-4, mas parece ter mais especificidade para o STAT-4 [58, 59].

Embora a IL-12 tenha sido a primeira citocina heterodimérica descrita, hoje já se conhece pelo menos outras quatro citocinas como IL-23 e IL-27, que compartilham semelhanças estruturais e funcionais com a IL-12 [60]. A IL-23 é uma citocina formada pela cadeia IL-23p19, que é homóloga a IL-12p35, associada à cadeia IL-12p40. Ou seja, os animais nocautes para IL-12p40 apresentam também uma deficiência para a IL-23. As funções exercidas pela IL-23 têm semelhanças com a IL-12 na indução da produção de IFN- $\gamma$, na diferenciação das células T para Th1 e na ativação das células apresentadoras de antígenos [61].

A importância da IL-12 no desenvolvimento das respostas imunes celular e humoral tem sido mostrada com a administração de IL-12 recombinante (rIL-12), assim a IL-12 induz e mantém a geração in vivo de células Th1 de memória e efetoras, induzindo a produção de IFN- $\gamma$ por células T e células NK [62]. Camundongos deficientes em IL12 apresentam resposta Th1 deficiente e têm susceptibilidade aumentada em relação a doenças infecciosas em que a proteção primária é mediada por IFN- $\gamma$, como leishmaniose e tuberculose [63].

Uma das principais funções da citocina IL-12 é a indução da produção de IFN- $\gamma$, já que a maioria dos seus efeitos pró-inflamatórios é IFN- $\gamma$-dependente. Neste aspecto, a IL-12 produzida pelas APC age sobre as células T e NK, induzindo a produção de IFN- $\gamma$ e este, por sua vez, age sobre as APC, ativando-as. Assim, a interação entre a IL-12 e o IFN- $\gamma$ leva a um potente mecanismo de feedback positivo, importante para o controle de infecções mediado por células [64].

Outra citocina que participa da polarização Thi é o IFN. Inicialmente, os IFN foram descobertas devido à sua potente atividade antiviral, no caso, os interferons do 
tipo I (IFN- $\alpha$ e IFN- $\beta$ ). O IFN do tipo II ou IFN- $\gamma$ é mais importante nas infecções microbianas $[65,66,67]$.

O IFN- $\gamma$, uma glicoproteína homodimérica, é uma citocina pleiotrópica amplamente envolvida na regulação tanto da imunidade inata, quanto da imunidade adquirida. Suas principais funções incluem as propriedades antivirais e antiproliferativas, ativação de macrófagos, controle de apoptose e promoção do processamento e apresentação de antígeno, "burst oxidativo" e morte de microorganismos intracelulares. O IFN- $\gamma$ atua principalmente como inibidor da polarização da resposta Th2 ao aumentar a expressão de IL-12R e aumenta a produção de IL-12 pelas APC. Ele promove também a mudança de classe de anticorpo para IgG2a e IgG3, além de aumentar a atividade das células NK, promovendo a morte de parasitas [68, 69, 70].

A ação do IFN- $\gamma$ é mediada por um receptor específico, o receptor de IFN- $\gamma$ (IFN$\gamma \mathrm{R})$. Este receptor é constituído por duas cadeias $(\alpha$ e $\beta)$. A cadeia $\alpha$, também chamada de IFN- $\gamma$ R1 ou CD119, é uma glicoproteína de 90 kDa, enquanto a cadeia $\beta$ ou IFN- $\gamma$ R2 é uma proteína de 60-67 kDa [71]. A sinalização se dá através dos receptores R1 e R2 pelos membros da família de proteínas JAK1 e JAK2; JAK1 está associada à cadeia $\alpha$ e a JAK2 esta associada à cadeia $\beta$. A ativação das JAKs leva à fosforilação do receptor STAt-1, fazendo com que ele seja translocado para o núcleo onde ocorrerá a regulação dos promotores para o IFN- $\gamma[71,72,73]$.

Acredita-se que a produção de IFN- $\gamma$ por macrófagos tenha influência nos estágios iniciais da resposta imune. Sendo estas células os primeiros mecanismos de defesa do organismo, sua ativação influenciará não só a imunidade inata, mas também o desenvolvimento da imunidade adquirida, determinando precocemente os rumos da resposta imune e alterando o balanço Th1/Th2 já durante a apresentação de antígenos. 


\subsection{Resposta imune adaptativa de padrão Th2}

Existem várias citocinas que participam da polarização da resposta imune para um padrão Th2, tais como: IL-4, IL-10, IL-13 e IL-5. Porém, as principal citocina que regula essa diferenciação é a citocina IL-4, enquanto a citocina IL-10 regula o balanço Th1/Th2 [74].

A citocina IL-10 é uma importante citocina imunoregulatória, ou seja, é antiinflamatória em determinadas circunstâncias, pois umas das suas principais funções é inibir a produção de IFN- $\gamma$ e IL-12, isto é, inibir a resposta Th1. É uma glicoproteína homodimérica com dois receptores de superfície, o IL-10R1 e IL-10R2. A sinalização da citocina IL-10 se dá através dos receptores R1/R2, que fosforilam os sítios de sinalização para os fatores de transcrição STAT-1 e STAT-3 [74]. Sua principal função está envolvida com a modulação de doenças alérgicas em humanos, pela mudança de classe do anticorpo para IgG4, inibição da expressão de moléculas co-estimulatória, como B7-1/2 e CD-28, inibição da produzir IFN- $\gamma$ por macrófagos e células NK e indução da produção de citocina IL-4 [75]. Além disso, a citocina IL-10 limita a produção de outras citocinas pró-inflamatórias, tais como IL-6, IL-18, IL-1 $\alpha$ e $\beta$, TNF- $\alpha$ e quimiocinas, como MCP-1, RANTES, MIP-2 e IP-10 [75].

A citocina IL-4 também está envolvida com o desenvolvimento de doenças alérgicas. Ela é muito importante na resposta humoral e em reações alérgicas das vias respiratórias, principalmente na asma brônquica. A IL-4 é uma glicoproteína homodiméricas com um receptor $(\mathrm{IL}-4 \mathrm{R} \alpha)$. A via de sinalização também se dá pelas janus-quinases, que induz a fosforilação do fator de transcrição STAT-6 e é essencial para diferenciação do perfil Th2 [76].

Por fim, durante a diferenciação para o perfil Th2, temos a participação das citocinas IL-5 e IL-13, que estão envolvidas com asma, doenças causadas por helmintos e hipersensibilidade causada por drogas. Elas são uma proteína homodimérica produzida 
principalmente pelas células Th2 após um estímulo causado por Mycobacterium ou um alérgeno e faz a mudança de classe do anticorpo para IgE [76].

\subsection{Principais Fatores Transcricionais Envolvidos na Polarização Th1/Th2}

Os linfócitos $\mathrm{T}$ CD4+ podem se diferenciar em linfócitos secretores de citocinas de padrão Th1 ou Th2. Isso dependerá do tipo do agente patogênico responsável pela infecção ou se é um processo independente de agente infeccioso, do estímulo antigênico e, principalmente, do microambiente, onde citocinas são produzidas [76].

Os principais fatores de transcrição envolvidos na polarização para um padrão Th1 são T-bet e STAT-4, enquanto para polarização do perfil Th2, os fatores transcricionais envolvidos são STAT-6 e GATA-3. Esses fatores são responsáveis pela manutenção e sobrevivência das células Th1 e Th2, respectivamente [77].

As células Th2 dependem de uma ativação via TCR que induzirá a expressão do receptor para citocina IL-4. Uma vez o receptor ativado, ocorrerá a ativação do fator transcricional STAT-6, que subseqüentemente irá regular a ativação de um segundo fator transcricional, o GATA-3. Este fator tem uma função central na remodelação da cromatina para diferenciação do perfil Th2. Sua deleção resulta em uma menor produção de células Th2 [77].

Para as células Th1, o processo de diferenciação é quase semelhante ao descrito para as células Th2. Citocinas, como a IL-12 e o IFN- $\gamma$, ativam o fator transcricional STAT-4 e, conseqüentemente, ocorrerá a ativação do fator de transcrição T-bet, que por fim induzirá uma remodelação da cromatina com diferenciação para um padrão Th1. Da mesma forma, a deleção do fator transcricional T-bet leva a uma deficiência de resposta Th1 [78].

Vanessa N. de Paiva 


\subsection{Participação citocinas e dos fatores}

\section{transcricionais relacionados a diferenciação dos} padrões Th1 e Th2 na lesão de Isquemia e

\section{Reperfusão}

Existem sub-populações de linfócitos T CD4+ caracterizadas pelo perfil de citocinas que secretam, entre elas, os linfócitos Th1, Th2 e Th17, sendo que o padrão de diferenciação é determinado por estímulos presentes logo no início da resposta imune. O mais importante estímulo de indução da diferenciação é constituído pelas citocinas, sendo a IL-12 a principal citocina indutora de células Th1, a IL-4 de células Th2, como já descrito nos tópicos acima (Figura 1).

Nas células Th17, as principais citocinas envolvidas são IL-6 e TGF- $\beta$ e o fator de transcrição envolvido para polarição Th17 é o ROR $\gamma$ T. As células Th17 estão envolvidas principalmente nas doenças auto-imunes. Já na lesão de $\mathrm{I} / \mathrm{R}$ renal, ainda não foi demonstrado se a população celular Th17 está envolvida, mas estudos realizados até o momento em nosso laboratório demonstraram ausência da citocina IL-17 no rim, por meio da análise por real time PCR em camundongos submetidos à lesão de $\mathrm{I} / \mathrm{R}$ após 6 e 24 horas (dados não publicados) [79, 80] (Figura 1.1).

Foi demonstrada também na lesão de $\mathrm{I} / \mathrm{R}$ que animais deficientes em STAT-4 eram protegidos da lesão renal e animais deficientes em STAT-6 apresentavam maior dano renal quando comparados com animais-controle [81].

Tendo em vista a dualidade de ações dos linfócitos com perfis Th1 e Th2, e como é importante sua participação na resposta imune, nos propomos, como um dos objetivos deste trabalho, avaliar o papel de citocinas Th1 e Th2 na lesão de I/R renal. Para tanto, trabalhamos com um modelo experimental com animais nocautes e duplos- 


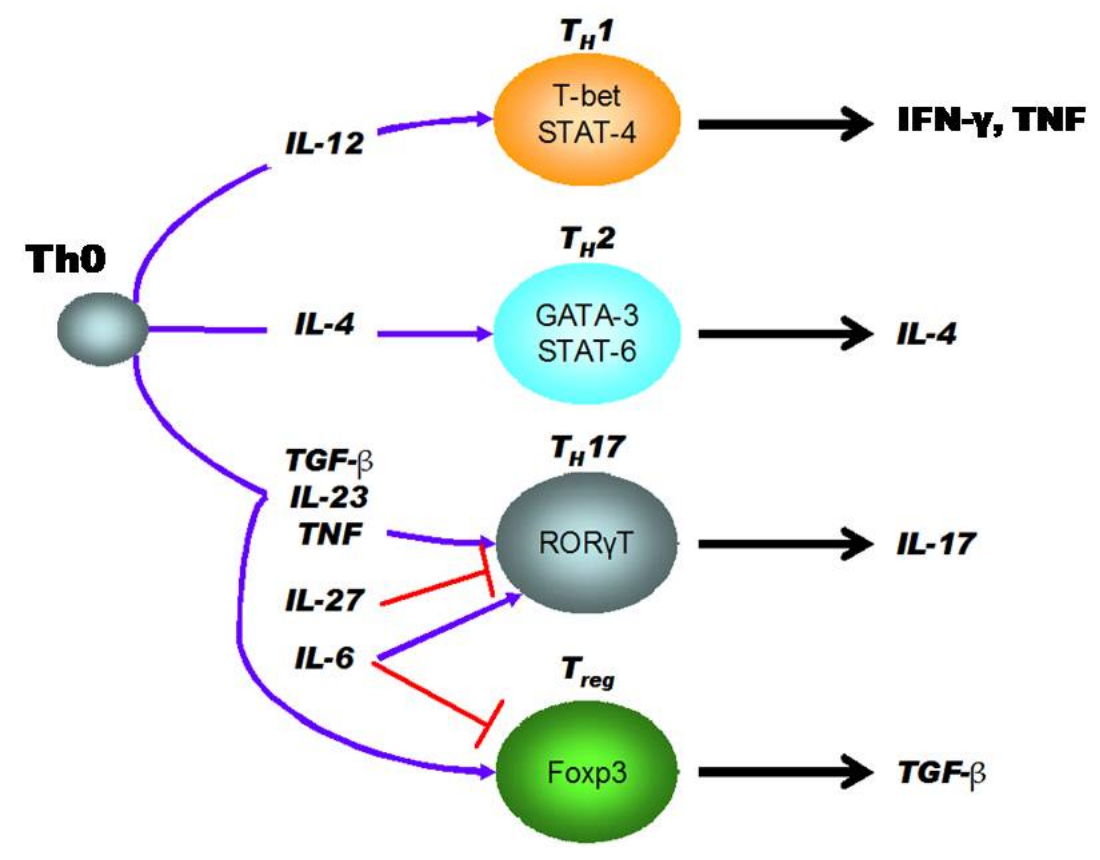

Figura 1.1.: Diferenciação e regulação das sub-populaçôes das células T CD4+, Th1, Th2, Th17 e diferenciação das células T reguladoras (Treg) em camundongos. Adaptado de Lawrence Steinman, Nat. Med. 13(3):385, $200 \%$.

nocautes para algumas citocinas cruciais para a diferenciação ou para o mecanismo efetor Th1/Th2. Em nosso laboratório, Marques e colaboradores já demonstraram o papel balanço Th1/Th2 na lesão I/R, na qual os animais IL-12 nocautes apresentavam menores níveis de uréia, de necrose tubular aguda e da expressão de MCP-1, quando comparados com os animais IL-4 nocautes e com os controles selvagens. Tudo isso nos levou a aprofundar e a testar a hipótese de que o perfil Th1 seria deletério e o perfil Th2, protetor para o tecido renal isquêmico [82].

\subsection{Heme-oxigenase e lesão de I/R}

Um crescente número de dados sugere que a expressão de heme-oxigenase (HO-1) endógena inibe a lesão de I/R [83, 84]. Respostas teciduais protetoras têm sido relatadas em vários modelos experimentais de lesão de I/R. O exemplo clássico é o descrito no 
pré-condicionamento, no qual animais submetidos a pequenos períodos de isquemia são protegidos de futuros insultos [85]. Uma das explicações para esse fato relaciona-se ao aumento da expressão de moléculas protetoras como a HO-1. As heme-oxigenases são enzimas que podem degradar o heme e manter a homeostasia celular, ao afetar os níveis de hemoproteína [86, 87]. Essas enzimas foram originalmente caracterizadas em 1968 e são conhecidas por produzirem efeitos citoprotetores em diversos modelos celulares e de lesão tecidual in vivo e in vitro [88]. Existem três isoformas dessa proteína: HO-1, que é uma forma induzível conhecida como heat shock protein-32 (Hsp-32); HO-2, que é expressa constitutivamente em vários tipos de células, incluindo as células endoteliais; HO-3 [89, 90], que é atualmente homóloga a HO-2. No entanto, vários autores têm mostrado que HO-3 não está presente em camundongos e humanos [91, 92]. Somente HO-1 e HO-2 são capazes de atuar como enzimas que podem catabolizar a heme em três produtos: monóxido de carbono ( $\mathrm{CO})$, biliverdina, que é rapidamente convertida em bilirrubina pela ação da biliverdina redutase [93, 94], e ferro livre, que leva à indução de ferritina, uma proteína ligada ao ferro [95, 96].

A biliverdina provavelmente exerce outros efeitos protetores (incluindo anti-apoptótico), em grande parte devido à sua propriedade anti-oxidante [97, 98]. A HO-1 também libera $\mathrm{Fe}^{2+}$ do núcleo da molécula heme, levando a uma rápida expressão da proteína seqüestradora de ferro (ferritina), assim como uma bomba de ATPase que remove ativamente o $\mathrm{Fe}^{2+}$ intracelular da célula [95]. Já o CO tem sido visto como uma substância tóxica, no entanto, esses efeitos tóxicos são vistos em concentrações bem acima das usadas experimentalmente [88].

O mecanismo pelo qual HO-1 confere esse efeito protetor ainda não está claro e requer uma intensa pesquisa. O que está claro, no entanto, é que esse mecanismo não é só justificado pela habilidade da HO-1 em diminuir o ferro livre gerado durante a lesão de I/R, mas também pela geração de produtos finais via degradação da heme, 
por exemplo, biliverdina, $\mathrm{Fe}^{2+}$ e $\mathrm{CO}$ [88]. Geração de biliverdina pela HO-1 tem um potente efeito protetor que pode também contribuir para prevenir a lesão de $\mathrm{I} / \mathrm{R}$. A biliverdina contribui de maneira significativa para o efeito citoprotetor da HO-1 [99]. Ela inibe a expressão de genes pró-inflamatórios associados à ativação de células endoteliais [100]. Além disso, CO pode induzir funções biológicas que são habilidades em diminuir a expressão de citocinas inflamatórias de monócito/macrófago ativados e de proteger células endoteliais de sofrerem apoptose durante I/R [101].

Nosso grupo demonstrou que animais selvagens tratados com ciclosporina apresentavam maior taxa de necrose tubular em diferentes tempos após a lesão de I/R renal, mas, quando esses animais eram pré-tratados com um indutor de HO-1, apresentavam uma melhora renal [102]. Em outro estudo, em nosso laboratório, animais selvagens tratados com rapamicina apresentavam uma maior disfunção renal após 24 e 120 horas da lesão de I/R renal, mas, após a indução de HO-1, esses animais vieram apresentar uma melhora da disfunção renal, demonstrando que a modulação da expressão de HO-1 representa uma maneira flexível de limitar a toxicidade renal aguda [103].

Dessa forma, resultados preliminares, que não iremos apresentar nessa tese, demonstraram que a indução de HO-1 melhorou a função renal dos animais nocautes para citocina IL-4. Esses animais tratados previamente com o indutor (Cobalto protoporfirina) de HO-1 apresentaram menor necrose tubular aguda e menor expressão de RNAm da citocina pró-inflamatória IL-6 (dados ainda não publicados). 
2. Objetivos 
Usando um modelo experimental de lesão de I/R em animais nocautes ou duplonocautes para citocinas críticas para o desenvolvimento de uma resposta Th1/Th2, nosso trabalho teve por objetivos:

1. Analisar as alterações funcionais e morfológicas renais em camundongos normais, deficientes em IL-12, IL-4, IFN- $\gamma$ e IL-10, duplo deficientes IL-10/IL-12 e em IFN$\gamma /$ IL-12, submetidos à I/R renal com 24 horas de reperfusão;

2. Quantificar a produção das citocinas IL-6 e da quimiocina MCP-1 nos camundongos normais, deficientes em IL-12, IL-4, IFN- $\gamma$ e IL-10, duplo deficientes IL-10/IL12 e em IFN- $\gamma /$ IL-12, submetidos à I/R renal com 24 horas de reperfusão;

3. Estudar a resposta protetora tecidual, pela análise molecular da expressão de RNAm de HO-1, nos camundongos normais, deficientes em IL-12, IL-4, IFN- $\gamma$ e IL-10, duplo deficientes IL-10/IL-12 e em IFN- $\gamma /$ IL-12, submetidos à I/R renal com 24 horas de reperfusão;

4. Evidenciar a polarização da resposta imune Th1/Th2 após a lesão renal pela I/R, nos camundongos normais, deficientes em IL-12, IL-4, IFN- $\gamma$ e IL-10, duplo deficientes IL-10/IL-12 e em IFN- $\gamma /$ IL-12 submetidos à I/R renal com 24 horas de reperfusão, pela análise molecular da expressão de RNAm em tempo real de T-bet (Th1) e GATA-3 (Th2);

5. Analisar a função renal, análise morfológica e a expressão do RNAm da citocina IL-6 nos animais selvagens reconstituídos com medula óssea de animais nocautes em IL-12 e IL-4 e seus controles submetidos à I/R renal com 24 horas de reperfusão. 
3. Materiais e Métodos 


\subsection{Modelo Experimental Isquemia e Reperfusão Renal}

Os experimentos foram realizados de acordo com a Lei Federal 6638 de 1979 que regulamenta o emprego de animais em experimentação científica, após a aprovação da Comissão de Ética da Universidade de São Paulo, com protocolo número 092 nas folhas 35 do livro 2, para uso de animais em experimentação.

O modelo experimental utilizado foi o descrito por Kelly e colaboradores [104] e adaptado por Pinheiro [46]. Foram usados camundongos C57BL/6 (H2-IAb) selvagens (como controles normais) e camundongos C57BL/6 geneticamente modificados (nocautes) e deficientes nas seguintes citocinas: IL-12p40 (aqui denominado IL-12 nocaute), IL-4, IFN- $\gamma$, IL-10, IL-10/IL-12 e IFN- $\gamma /$ IL-12. Todos os animais eram machos, com idade entre 8 e 12 semanas, pesando de 20 a 28 g e isogênicos.

Os animais foram submetidos à anestesia com ketamina e xilazina (Agribrands do Brasil, São Paulo, Brasil), diluída em solução fisiológica de cloreto de sódio a 0,9\% (SF) (Sanobiol, Pouso Alegre, Brasil) por via intraperitoneal [6], na dose de $100 \mathrm{mg} / \mathrm{Kg}$ de peso de ketamina e $10 \mathrm{mg} / \mathrm{Kg}$ de peso de xilazina. Esta dose promovia anestesia por cerca de uma hora. Caso necessário, era administrado dose adicional de $20 \%$ da inicial [105]. Uma vez anestesiados, os animais eram fixados na mesa cirúrgica em decúbito dorsal e procedia-se à anti-sepsia do abdome com álcool iodado a $2 \%$. Durante o procedimento cirúrgico, os animais foram aquecidos por iluminação indireta. Utilizando o microscópio cirúrgico (DF Vasconcellos, São Paulo, Brasil), que permite aumento de 6 a 30 vezes, procedeu-se à incisão xifopubiana mediana, expondo assim as vísceras abdominais. Em seguida, as vísceras eram rebatidas para o tórax, protegidas por compressa de gaze umedecida em SF. Exposto o retroperitônio, os pedículos renais eram dissecados e isolados. Promovia-se então a isquemia renal por ligadura do pedículo com clamps 


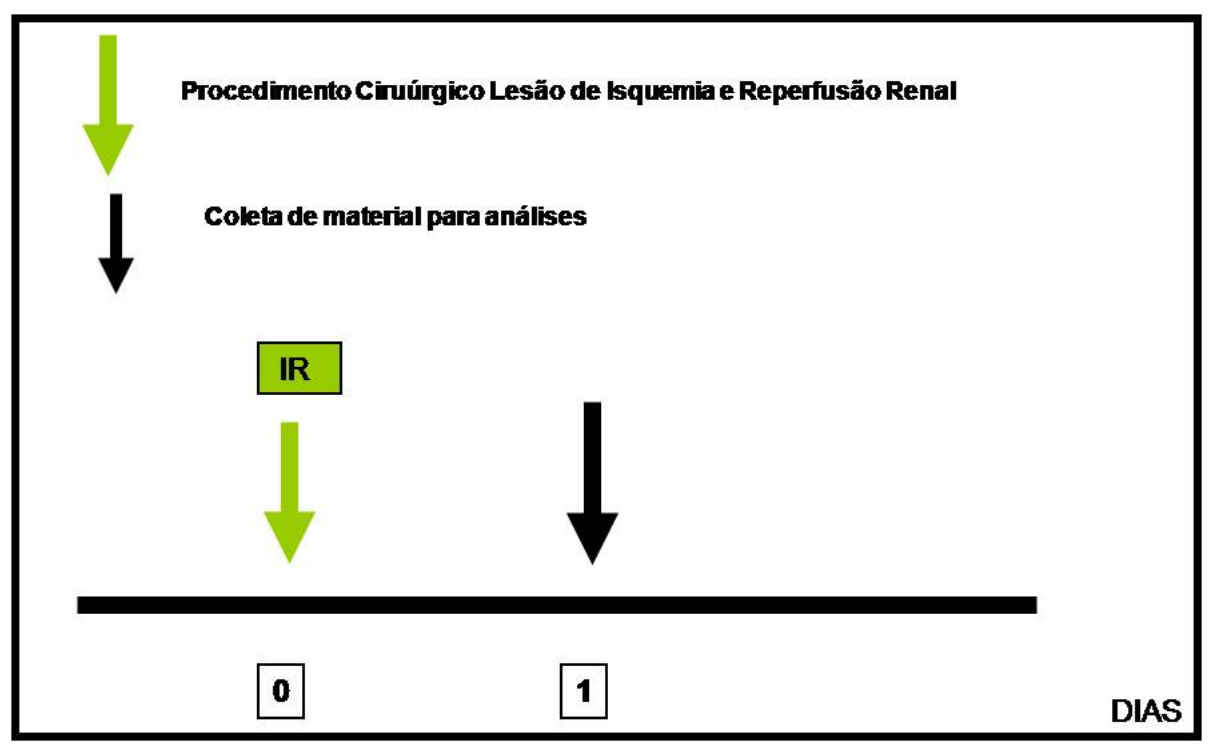

Figura 3.1.: Esquema do protocólo de estudo de $I / R$.

microvasculares (Rocca, São Paulo, Brasil) durante 45 minutos. Antes do fechamento da cavidade, o animal recebia $0,5 \mathrm{~mL}$ de $\mathrm{SF}$ aquecido intraperitoneal. Reaberta a cavidade abdominal, os clipes eram retirados e observava-se a completa reperfusão dos rins e a ausência de trauma nos pedículos. Os animais-controle "sham" foram submetidos aos mesmos procedimentos cirúrgicos, mas sem a ligadura bilateral dos pedículos renais. O fechamento da cavidade foi feito com pontos cirúrgicos contínuos em dois planos (aponeurose e pele) com fios de seda tamanho 4-0, (Technofioß, Goiânia, Brasil). Os animais foram mantidos em aquecimento por iluminação indireta até a completa recuperação da anestesia. A seguir, os animais foram mantidos na estante ventilada do laboratório, acondicionados em gaiolas coletivas, contendo no máximo cinco animais, com ciclo artificial claro/escuro de 12 horas, em uma temperatura ambiente constante de $22^{\circ} \mathrm{C}$ e com suprimentos de água autoclavada e alimentos disponíveis o tempo todo.

O protocolo experimental é detalhado na figura 3.1. Fotos representativas do procedimento cirúrgico e do aspecto macroscópico dos rins reperfundidos por 24 horas são demonstradas na figura 3.2. 
(A)

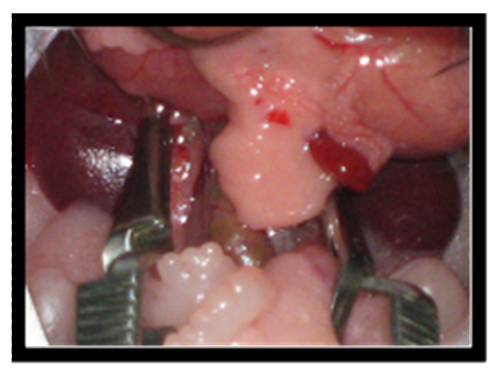

(B)

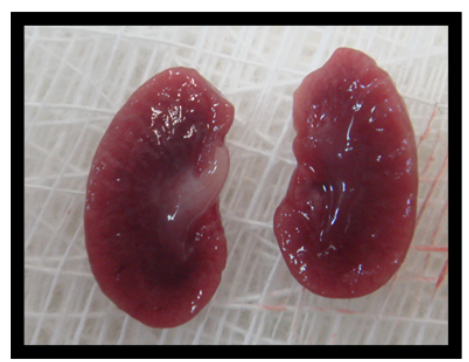

Figura 3.2.: Fotos representativas do procedimento cirúrgico (A) e do aspecto macroscópico dos rins isquemiados e reprefundidos por 24 horas $(B)$.

\subsection{Grupos Experimentais}

Os camundongos foram divididos em vários grupos, a saber:

1. Grupo dos camundongos C57BL/6 normais (selvagens) submetidos ao procedimento cirúrgico;

2. Grupo dos camundongos C57BL/6 deficientes em IL-12 (IL-12 nocautes) submetidos ao procedimento cirúrgico;

3. Grupo dos camundongos C57BL/6 deficientes em IL-4 (IL-4 nocautes) submetidos ao procedimento cirúrgico;

4. Grupo dos camundongos C57BL / 6 deficiente em IFN- $\gamma$ (IFN- $\gamma$ nocautes $)$ submetidos ao procedimento cirúrgico;

5. Grupo dos camundongos C57BL/6 deficiente em IL-10/IL-12 (IL-10/IL12 duplo nocautes) submetidos ao procedimento cirúrgico;

6. Grupo dos camundongos C57BL/6 deficiente em IFN- $\gamma /$ IL-12 (IFN$\gamma /$ IL-12 duplo nocautes) submetidos ao procedimento cirúrgico.

7. Grupo dos camundongos C57BL/6 deficiente em IL-10 (IL-10 nocautes) submetidos ao procedimento cirúrgico. 
Em todos os grupos foram feitos animais-controle (sham), nos quais eles eram submetidos ao procedimento cirúrgico, com exposição das vísceras e dissecamento dos pedículos renais, mas sem a ligadura reversível das artérias renais.

Vinte e quatro horas após a cirurgia, os camundongos foram anestesiados com ketamina e xilazina, na mesma dose descrita anteriormente, e colhidas amostras de sangue e tecido renal para posterior análise. Em seguida à coleta, os camundongos eram sacrificados por deslocamento cervical.

Os grupos-controle possuíam 4 animais e o grupo isquemiado, cinco. Para as análises, animais normais, não manipulados, foram também estudados $(\mathrm{N}=3)$. Para título de comparação, sempre que foram realizados os experimentos de $\mathrm{I} / \mathrm{R}$, animais selvagens e nocautes eram usados de forma pareada.

\subsection{Modelo Experimental de Transferência Adotiva de Medula Óssea}

Células totais da medula óssea foram obtidas do fêmur e da tíbia dos camundongos nocautes para citocinas IL-12, IL-4 e de animais-controle C57BL/6. Após a dissecção desses ossos com um bisturi, eles foram mantidos em PBS e, em seguida, em um fluxo laminar, com ajuda de uma seringa de $10 \mathrm{~mL}$ acoplada a uma agulha de insulina. O conteúdo dos ossos foram removidos com a ajuda de meio RPMI de cultura contendo $5 \%$ de soro bovino fetal. O osso foi lavado várias vezes com meio de cultura até ficar completamente sem a medula óssea. Essas células foram centrifugadas a 4 oC durante dez minutos a $13.000 \mathrm{rpm}$ e, em seguida, as células foram ressuspensas em $3 \mathrm{~mL}$ de tampão de lise ACK (solução de lise eritrocitária: NH4Cl - cloreto de amônio 0,15M; KHCO3 - bicarbonato de potássio 1mM; Na2EDTA - EDTA sódico 0,1mM; pH 7.2-7.4) e mantidas no gelo. Após 10 minutos, a suspensão celular foi centrifugada novamente e 
as células ressuspensas em $10 \mathrm{~mL}$ de meio de cultura RPMI contendo 5\% soro bovino fetal. A viabilidade celular foi aferida por meio do uso de corante Azul de Tripan (Trypan Blue, Sigma, St. Louis. USA). As células vivas foram contadas na câmara de Neubauer (0,0025 mm2, Reichert, Buffalo,USA) e injetadas intraperitonealmente $(20 \mathrm{x}$ 106 células por animal). Porém, antes os camundongos receptores da medula óssea foram submetidos à irradiação por cobalto durante vinte minutos a 1200 rads para depleção subletal da medula óssea. Durante seis semanas, esses camundongos foram mantidos no biotério da Universidade de São Paulo do ICB IV com suprimento de água autoclavada e ração. Após seis semanas, esses animais foram submetidos ao processo cirúrgico de ligadura bilateral dos pedículos renais e, 24 horas após a cirurgia, os animais foram sacrificados e coletados rins e sangue para análise funcional. O baço e os linfonodos foram removidos para análise das populações celulares reconstituídas, especificamente os linfócitos $\mathrm{T}$ CD3+, CD4 + e CD $8+$, por citometria de fluxo.

\subsection{Os animais foram agrupados da seguinte forma}

1. Grupo dos camundongos deficientes em IL-12 (IL-12 -/- nocautes $\rightarrow$ C57BL/6) submetidos ao procedimento cirúrgico;

2. Grupo dos camundongos C57BL/6 (WT $\rightarrow$ IL-12 -/-) submetidos ao procedimento cirúrgico;

3. Grupo dos camundongos deficientes em IL-4 (IL-4 -/- $\rightarrow$ WT) submetidos ao procedimento cirúrgico;

4. Grupo dos camundongos deficientes em IL-4 (WT $\rightarrow$ IL-4 -/-) submetidos ao procedimento cirúrgico;

5. Grupo dos camundongos deficientes em IL-4 (WT $\rightarrow$ WT) submetidos ao 
procedimento cirúrgico;

Em todos os grupos foram feitos animais-controle (sham), nos quais eles eram submetidos ao procedimento cirúrgico, com exposição das vísceras e dissecamento dos pedículos renais, mas sem a ligadura reversível das artérias renais.

Vinte e quatro horas após a cirurgia, os camundongos foram anestesiados com ketamina e xilazina, na mesma dose descrita anteriormente, e colhidas amostras de sangue e tecido renal para posterior análise. Em seguida à coleta, os camundongos eram sacrificados por deslocamento cervical.

Os grupos-controle possuíam 3 animais e o grupo isquemiado, três. Para as análises, animais normais, não manipulados, foram também estudados $(\mathrm{N}=3)$. Para título de comparação, sempre que foram realizados os experimentos de I/R, animais selvagens e nocautes eram usados de forma pareada.

Esquema do protocólo de estudo da transferência adotiva de células totais da medula óssea, são ilustrados nas figuras 3.3 e 3.4 .

\subsection{Parâmetros Estudados}

Nos animais de todos os grupos, foram estudados os parâmetros funcionais e histológicos.

\subsubsection{Peso}

O peso, em gramas, dos camundongos foi verificado no dia do procedimento cirúrgico e no dia do sacrifício, a fim de avaliar as médias de perda de peso dos camundongos entre os dois tempos no período do experimento, analisando-se as variações entre os grupos sham e isquemiados. 


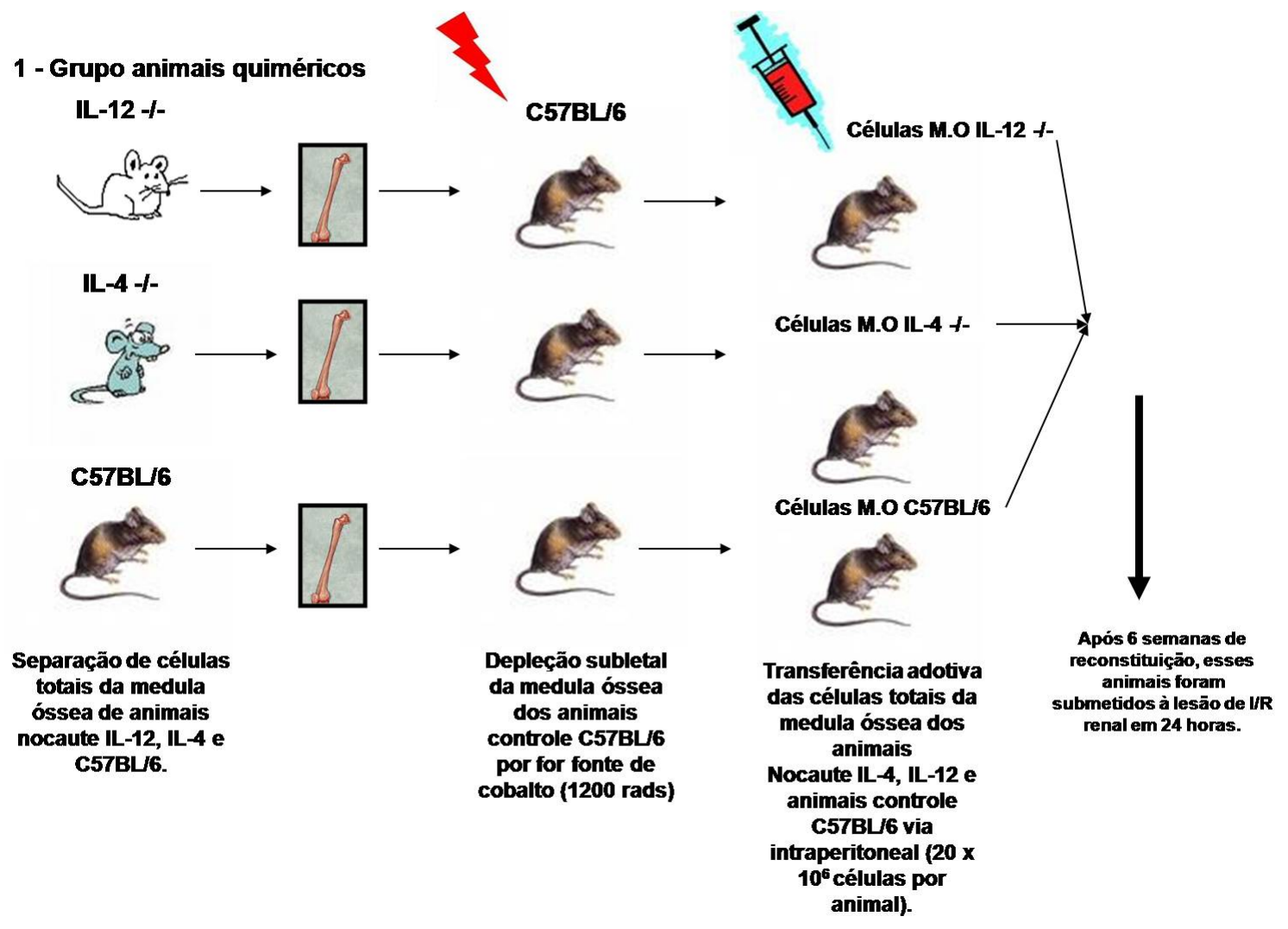

Figura 3.3.: $1^{o}$ esquema do protocólo do estudo de transferência adotiva de células totais da médula óssea dos animais nocaute para citocinas IL-4 e IL-12 para os animais controle-selvagem. 


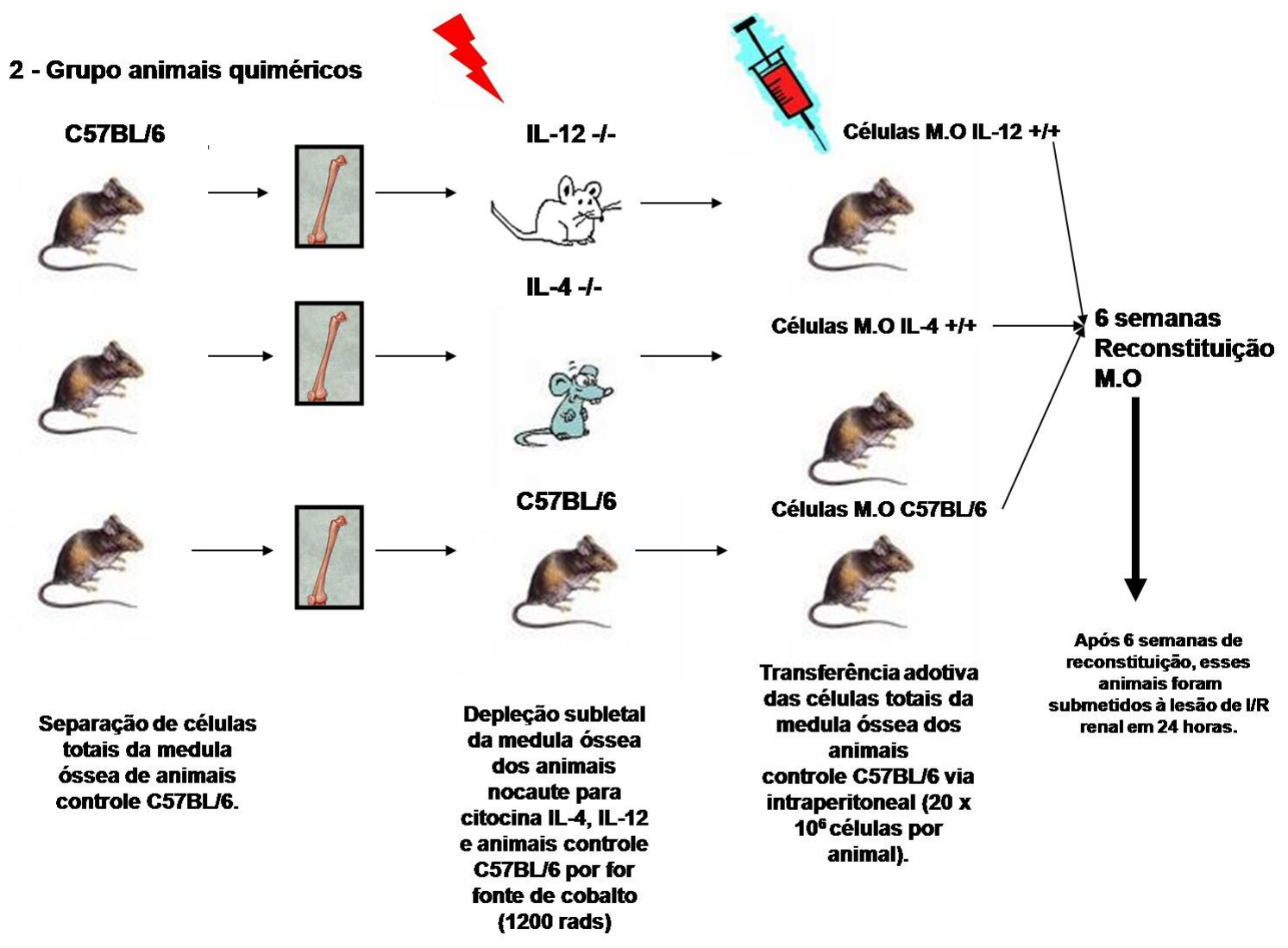

Figura 3.4.: $1^{\circ}$ esquema do protocólo do estudo de transferência adotiva de células totais da médula óssea dos animais controle-selvagem para os animais nocautes para citocinas $I L-4$ e IL-12. 


\subsubsection{Função renal Creatinina}

Para a medida da função renal, a creatinina foi aferida nos soros dos animais pelo método de Jaffé modificado. Os soros foram homogeneizados em Vórtex e centrifugados por 6 minutos, à velocidade de $10000 \mathrm{rpm}$. Após este procedimento, procedeu-se à desproteinização com ácido sulfúrico 1,84\% e tungstato de sódio 10\%. Posteriormente, adicionou-se ácido pícrico a $2 \%$ e hidróxido de sódio a 10\%. Agitou-se durante uma incubação de 15 minutos a $25^{\circ} \mathrm{C}$ e a leitura foi feita no aparelho de ELISA (Spectra Max 190, Molecular Devices, EUA) numa absorbância de 520 nm.

O cálculo da concentração de creatinina sérica (em $\mathrm{mg} / \mathrm{dL}$ ) foi feito através da fórmula:

$$
\mathrm{Cr}=\text { absorbância à } 520 \mathrm{~nm} \times \text { fator calculado }(\mathrm{F})
$$

Sendo que $\mathrm{F}$ = média dos fatores calculados a partir dos fatores dados pelos padrões de creatinina de $0,5,1,0$ e 2,0 .

O valor normal de creatinina é $0,5 \mathrm{mg} / \mathrm{dL}$.

\subsubsection{Uréia}

A função renal também foi avaliada pelos valores de uréia sérica coletada nos pontos do estudo 24 horas após a I/R renal. Foram colhidos $500 \mu \mathrm{l}$ de sangue por animal pela punção da veia cava inferior ou pelo plexo ocular. O sangue foi centrifugado por 15 minutos a 15.000 g para separação do soro. Utilizou-se o kit Uréia, (Labtest Diagnóstica SA, Brasil).

Adicionou-se em tubos eppendorfs $1000 \mu \mathrm{L}$ de urease tamponada a $10 \mu \mathrm{L}$ de soro, sendo depois homogeinizados em Vórtex e incubados a $37^{\circ} \mathrm{C}$ por 5 minutos em banho maria. Após isso, adicionou-se à cada tudo $1000 \mu \mathrm{L}$ do oxidante de uso que contém hidróxido de sódio 2,8 mol/L e hipoclorito de sódio (Uréia Ce - Labtest), homogeinizou- 
se e incubou-se novamente a $37^{\circ} \mathrm{C}$, por 5 minutos.

A leitura da absorbância foi feita no aparelho de ELISA (Spectra Max 190, Molecular Devices, EUA) por meio do programa Max pro em uma absorbância de $620 \mathrm{~nm}$.

O cálculo da concentração de uréia sérica (em $\mathrm{mg} / \mathrm{dL}$ ) foi feito através da fórmula:

$\mathrm{U}=($ absorbância $620 \mathrm{~nm}$ teste/absorbância $620 \mathrm{~nm}$ padrão $) \times 70$

O cálculo também foi feito no programa excel.

O valor normal de uréia é 50-70 mg/dL.

\subsection{Análise Histomorfométrica}

Sob anestesia com ketamina e xilazina, os animais foram submetidos à incisão xifopubiana mediana após anti-sepsia da pele com álcool iodado $2 \%$. O rim esquerdo foi retirado para análise de transcritos gênicos pela reação de polimerização em cadeia (PCR). O rim direito foi retirado e, após seccionada e retirada a cápsula renal, foi cortado na vertical em três fragmentos aproximadamente simétricos. O material foi fixado em formol 10\% tamponado até a montagem em blocos de parafina. Após processamento habitual, foi estudado pelo menos um corte de cada fragmento, na coloração de hematoxilina-eosina.

O estudo histomorfométrico avaliou a presença e a quantificação de necrose tubular (NT) e regeneração tubular (RT) na medula externa (ME) na coloração hematoxilinaeosina. Utilizou-se o programa KS300 (Zeiss) e um microscópio de luz comum.

Após a digitalização da imagem dos campos, era feita a seleção das áreas com características de necrose ou regeneração tubular, que eram então contabilizadas pelo programa. Os resultados eram expressos em percentagem de área acometida em relação à área total do campo avaliado $\left(145.846,7 \mu \mathrm{m}^{2}\right)$. Eram avaliados 25 campos de aumento 
de $835 \mathrm{X}$ por lâmina, escolhidos aleatoriamente, que praticamente cobriam toda a medula externa dos cortes. Com este número de campos, avaliou-se uma área de $3.646 .167,5 \mu \mathrm{m}^{2}$ ou 3,65 $\mathrm{mm}^{2}$ em cada animal por lâmina.

A análise era feita sem que o observador tivesse acesso à identificação de qual grupo pertencia o material analisado. Os resultados encontrados foram validados na totalidade dos casos por análise quantitativa feita por patologista, também sem identificação dos casos.

Foram consideradas alterações compatíveis com necrose tubular: perda da borda em escova, perda da integridade citoplasmática e nuclear, perda de células tubulares individuais, presença de cilindros hialinos preenchendo a luz tubular em substituição às células tubulares perdidas. Como alterações regenerativas foram consideradas: núcleos com cromatina não condensada, de tamanhos e formas não uniformes, presença de vários nucléolos e citoplasma menos basofílico [106, 107].

Os resultados obtidos da análise histomorfometria de necrose e regeneração tubular eram então correlacionados entre si nos tempos analisados.

A análise morfométrica foi realizada pela Profa. Marlene Antônia dos Reis, do Departamento de Patologia da Universidade Federal do Triângulo Mineiro.

\subsection{Análise dos Transcritos Gênicos}

\subsubsection{Amostras para biologia molecular}

Enquanto o rim direito foi retirado, fixado e montado em blocos de parafina (realizados cortes na espessura de $3 \mu \mathrm{m}$ e montados em lâminas sinalizadas como descrito no item acima), o rim esquerdo foi retirado em técnica asséptica e seccionado transversalmente em fragmentos, estocados a $-80^{\circ} \mathrm{C}$ para posterior extração de RNA total e realização de RT-PCR. 
Amostras de tecido renal foram analisados em relação à presença de transcritos gênicos de HPRT (hipoxantina-guanina fosforibosil-transferase), como controle da presença de RNA nas amostras, HO-1, como gene de proteção, t-bet, como marcador da via Th1 da resposta imune, GATA-3, como marcador da via Th2 da resposta imune, IL-6, como marcador de citocinas pró-inflamatórias, e MCP-1, gene marcador de quimiocina.

\subsubsection{Obtenção de fragmentos Renais}

Os fragmentos foram retirados em técnica asséptica com animais sob anestesia com ketamina e xilazina. Procedeu-se à incisão xifopubiana mediana e à exposição dos rins depois de rebatidas as vísceras abdominais para o tórax. Um fragmento do rim esquerdo foi retirado (aproximadamente $50 \mathrm{mg}$ ), colocado em tubo de poliestireno de 1,5 mL e imediatamente congelado em nitrogênio líquido. A seguir, as amostras foram homogeneizadas e manipuladas segundo o método de extração de RNA total TRIZOL LS Reagent (Life Technologies, New York, EUA), que será descrito posteriormente.

\subsubsection{Extração e purificação de RNA total - método TRIzol}

Um pequeno fragmento do rim, cerca de $50 \mathrm{mg}$, que estava estocado no freezer $80^{\circ} \mathrm{C}$, foi colocado em um eppendorf $1,5 \mathrm{~mL}$ contendo $1 \mathrm{~mL}$ de Trizol LS Reagent. O método utiliza solução monofásica de fenol e guanidina isotiocianato que lisa e dissolve componentes celulares, mantendo a integridade do RNA. As amostras de tecido renal suspensas em TRIZOL LS Reagent foram trituradas no homogenizador POLYTRON (Marconi, Brasil) e a estas foi adicionado clorofórmio (MERCK, Rio de Janeiro, Brasil) (0,2 mL de clorofórmio/1 mL de TRIZOL). Centrifugou-se a $4^{\circ} \mathrm{C}$ e a $12000 \mathrm{~g}$ por 15 minutos para a obtenção de duas fases, uma orgânica e outra aquosa, onde se encontra

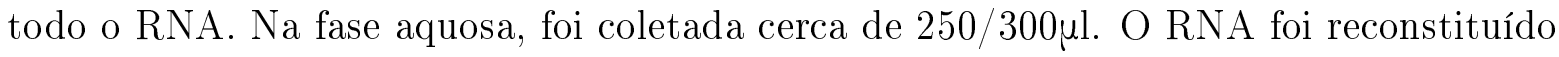
através da adição de isopropanol $80 \%$ do volume coletado (MERCK, Rio de Janeiro, 
Brasil) $\left(0,24 \mathrm{~mL}\right.$ de isopropanol $/ 1 \mathrm{~mL}$ de TRIzol) seguida de centrifugação a $4^{\circ} \mathrm{C}$ e a 12000 g por 10 minutos, obtendo-se o RNA precipitado. Após o isolamento, o RNA foi lavado com etanol a 75\% (MERCK, Rio de Janeiro, Brasil) (1mL de etanol $/ 1 \mathrm{~mL}$ de TRIzol) e novamente centrifugado a $4^{\circ} \mathrm{C}$ e a 12000 g por 10 minutos. O "pellet" de RNA formado foi ressuspenso em $50 \mu \mathrm{L}$ de água bidestilada livre de RNAse e DNAse (GIBCO BRL - Invitrogen, New York, EUA). Após esta etapa, quantificou-se o RNA diluído, utilizando-se o espectofotômetro nanodrop RNA/DNA/Proteína Calculator (ND1000, Cambridge, Inglaterra). Além da concentração de RNA das amostras, calculou-se a relação de medidas de densidade óptica nos comprimentos de ondas de 260/280 nm, sendo considerado ideal quando entre 1,6 e 1,8. O RNA total foi estocado a $-80^{\circ} \mathrm{C}$ até o uso.

\subsubsection{Síntese do DNA complementar (cDNA)}

A partir do RNA total extraído, procedeu-se à síntese do cDNA utilizando-se $2 \mu \mathrm{g}$ de RNA total de cada amostra estudada, tratado com 2,15 $\mu \mathrm{L}$ de DNAse Buffer e $1 \mu \mathrm{L}$ de DNAse, para eliminação de DNA contaminante, acrescido de água bidestilada livre de RNAse e DNAse, com um volume final de 21,5 $\mu \mathrm{L}$ de solução.

Para a reação de transcrição reversa, preparou-se uma solução contendo $10 \mu \mathrm{L}$ de tampão para a enzima transcriptase reversa cinco vezes concentrado ("5xRVT buffer", GIBCO BRL - Life Technologies, Gaithersburg, EUA), $10 \mu \mathrm{L}$ de desoxinucleotídeos (dNTP), com 10 mM de cada base (A,T,C e G), $2 \mu \mathrm{L}$ de oligo-dT $100 \mu \mathrm{g} / \mathrm{mL}$ (Amersham Pharmacia Biotech Inc, Piscataway, EUA), $1 \mu \mathrm{L}$ de BSA ("bovine serum albumin" Promega, Madison, EUA) inativada por acetilação $(1 \mathrm{mg} / \mathrm{mL}), 10 \mu \mathrm{L}$ de inibidor de RNAse ("RNAsin", Promega, Madison, EUA) e $10 \mu \mathrm{L}$ da enzima Transcriptase Reversa ("RVT-MMLV", GIBCO BRL - Life Technologies, Gaithersburg, EUA). A solução de volume final $60 \mu \mathrm{L}$ foi mantida a $37^{\circ} \mathrm{C}$ por 1 hora e em seguida a $65 \mu \mathrm{C}$ por 10 minutos, 


\begin{tabular}{c|c|c}
\hline "Primer" & Sequência & Concentração \\
\hline \hline HPRT Sense & 5'CTC ATG GAC TGA TTA TGG ACA GGA C3' & $25 \mathrm{nM}$ \\
HPRT Antisense & 5'GCA GGT CAG CAA AGA ACT TAT AGC C3' & $25 \mathrm{nM}$ \\
HO-1 Sense & 5'TGA CAC CTG AGG TCA AGC ACA3' & $25 \mathrm{nM}$ \\
HO-1 Antisense & 5'GTT CCT CTG TGA GCA TCA CCT G3' & $25 \mathrm{nM}$ \\
GATA-3 Sense & 5'AAG AGA ATC ACC AGC AGC AGG T3' & $25 \mathrm{nM}$ \\
GATA-3 Antisense & 5'TTC TGG ACC CAT TCC TTA TTG G3' & $25 \mathrm{nM}$ \\
T-bet Sense & 5'CCA GTA TCC TGT TCC CAG CC3' & $25 \mathrm{nM}$ \\
T-bet Antisense & 5'CAT AAC TGT GTT CCC GAG GTG TC3' & $25 \mathrm{nM}$ \\
IL-6 Sense & 5'TTT CTCATTTCCACGATTTCCC3' & $25 \mathrm{nM}$ \\
IL-6 Antisense & 5'AGGATACCACTCCCAACAGACCT3' & $25 \mathrm{nM}$ \\
MCP-1 Sense & 5'TAGAGATTGAGCTGTCTGCTCATTC3' & $25 \mathrm{nM}$ \\
MCP-1 Antisense & 5'CCTAAAGTATGGGCTGGACTGTTT3' & $25 \mathrm{nM}$ \\
\hline
\end{tabular}

Tabela 3.1.: Sequência (sense/antisense) e concentração dos "primers" utilizados no estudo na reação de Real Time PCR.

para inativar a transcriptase reversa. Foi estocada a seguir a $-80^{\circ} \mathrm{C}$ até seu uso na reação em cadeia da polimerase.

\subsubsection{Síntese dos “primers”}

Os "primers" utilizados no estudo foram: HPRT, como controle da presença de RNA, HO-1, como gene de citoproteção, t-bet, como marcador de ativação da via Th1, GATA-3, como marcador de ativação da via Th2, citocinas IL-6, como marcador de citocinas pró-inflamatórias, e MCP-1, como marcador de quimiocina. Os "primers" estudados foram desenhados por meio do uso do programa Primer Express (Applied Biosystems, USA), a partir das seqüências gênicas obtidas no GenBank, utilizando-se o "Nucleotide-Nucleotide Blast" para encontrar o par que apresentasse maior especificidade. As seqüências e as concentrações dos "primers" utilizados são apresentadas na Tabela 3.1. 


\begin{tabular}{c|c}
\hline Reagentes & Tubo teste $(\mu \mathrm{L})$ \\
\hline \hline SyBr Mix & 5,0 \\
Forward Primer $50 \mathrm{mM}$ & 0,4 \\
Reverse Primer $50 \mathrm{mM}$ & 0,4 \\
cDNA $\mu \mathrm{g} / \mu \mathrm{L}$ & 1,0 \\
Água DEPC & 3,8 \\
\hline
\end{tabular}

Tabela 3.2.: Reações (em triplicatas) de Real Time PCR com SyBr Green PCR Master Mix Kit (Applied Biosystems, USA). Volume final da reação: $10 \mu \mathrm{L}$.

\subsubsection{Reação de Real Time - PCR}

Após a determinação da melhor temperatura de anelamento para cada "primer" que foi padronizada pelo laboratório, foi feita a reação de PCR em tempo real com a quantificação relativa do número de cópias de cada gene alvo em relação aos trânscritos do gene controle HPRT. Como meio de se reduzir a variabilidade dependente de erros de pipetagem nos resultados, foram feitas pré-misturas contendo "primers", PCR Master Mix e água Milli Q em quantidades proporcionais ao número de amostras programadas em cada experimento. Após homogeneização em Vórtex, alíquotas desta mistura foram transferidas aos tubos onde, posteriormente, as amostras de cDNA seriam depositadas. As amostras foram, então, submetidas, em triplicatas, a 40 ciclos térmicos no ABI PRISM 770 Sequence Detector. Utilizou-se também o programa ADS v1.9 (Applied Biosystems, USA) para analisar as curvas de dissociação. As reações foram feitas com o SyBr Green PCR Master Mix kit (Applied Biosystems, USA) (Tabela 3.2).

As temperaturas em cada fase de execução do Real Time PCR foram então determinadas para todos os "primers" estudados, em um número de 45 ciclos no total, e são apresentadas na Tabela 3.3.

Nas análises, foi utilizado o valor do CP ("Crossing Point"). O CP consiste no ciclo em que o número de cópias de gene de interesse amplificado alcançou um ponto inicial acima da fluorescência padrão. O CP é determinado a fim de quantificar valores a partir de um ponto inicial. A quantificação relativa da expressão de RNAm foi calculada com 


\begin{tabular}{c|c}
\hline Fases do Real Time PCR & Temperatura/Tempo \\
\hline \hline Iniciação & $95^{\circ} \mathrm{C}$ por 10 minutos \\
Desnaturação & $95^{\circ} \mathrm{C}$ por 20 segundos \\
Anelamento do "primer" & $58^{\circ} \mathrm{C}$ por 20 segundos \\
Extensão & $72^{\circ} \mathrm{C}$ por 20 segundos \\
\hline
\end{tabular}

Tabela 3.3.: Temperaturas e tempos utilizados nas fases sequênciais do Real Time PCR.

a fórmula [108].

$$
\text { Ratio }=\frac{\mathrm{E}_{\text {gene alvo }}^{\text {CPalvo (controle-teste })}}{\mathrm{E}_{\text {housekeeping }}^{\text {CPhousekeeping (controle-teste) }}}
$$

Sendo: $\mathrm{E}=$ eficiência do Real Time PCR CP = "Crossing Point" D = diferença de controle interno versus teste.

Para a comparação da expressão gênica dos genes estudados acima entre todos os animais do grupo, os genes foram normalizados com o uso de cDNA de animais normais C57BL/6, no qual o valor de expressão do gene era sempre igual a 1.

\subsection{Geração do Controle Positivo}

Para obtenção do controle positivo para os genes estudados, fragmentos de baço de camundongo, foram macerados entre as bordas foscas de lâmina histológica, lavandose com 15-20 mL de meio de cultura celular RPMI (GIBCO BRL - Life Technologies, Rockville, EUA) em capela de fluxo laminar. Centrifugou-se por 6 minutos a $400 \mathrm{~g}$ e desprezou-se o sobrenadante. O "pellet" resultante foi ressuspenso em $3 \mathrm{~mL}$ de solução de lise de hemácias/baço e então se centrifugou a solução por 6 minutos a 400 g. Seguindose a essa etapa, foram feitas duas lavagens que consistiam de retirada de sobrenadante, ressuspensão em RPMI 1640 (GIBCO BRL - Life Technologies, Rockville, EUA) e centrifugação a 400 g por 3 minutos. Nesta etapa, após as lavagens, foi feita a contagem 
de células viáveis presentes na amostra, utilizando-se câmara de Neubauer e o corante vital azul de Tripan (Sigma Chemical Company, St. Louis, EUA).

Centrifugou-se novamente a solução contendo as células obtidas e ressuspendeu-se o "pellet" em 45 mL de meio RPMI (GIBCO BRL - Life Technologies, Rockville, EUA), suplementado com soro bovino fetal 10\% (GIBCO BRL - Life Technologies, Gaithersburg, EUA), Penicilina-100 U/mL (GIBCO BRL - Life Tecchnologies, Gaithersburg, EUA) e Estreptomicina-100 $\mu \mathrm{g} / \mathrm{mL}$ (GIBCO BRL - Life Technologies, Gaithersburg, EUA), colocados em garrafa de cultura de $75 \mathrm{~cm}^{2}$ (Corning, New York, EUA). Acrescentou-se, então, fitohemaglutinina (PHA - $5 \mu \mathrm{g} / \mathrm{mL}$, GIBCO BRL - Life Techonologies, Gaithersburg, USA) e forbol miristato (PMA, $10 \mathrm{ng} / \mathrm{mL}$, Sigma Chemical Company, St. Louis, EUA). Incubou-se por 48 horas a $37^{\circ} \mathrm{C}$ em estufa $\left(5 \% \mathrm{CO}_{2}\right)$, permitindo-se a proliferação celular até a formação de agregados celulares "em cachos".

Após o cultivo, procedeu-se a uma nova contagem do número de células em câmara de Neubauer, seguida de centrifugação a 400 g por 3 minutos. Descartou-se o sobrenadante e iniciou-se a extração de RNA total pelo método TRIzol LS Reagent.

\subsection{Genotipagem das diferentes linhagens de camundongos}

Os camundongos deficientes em IL-12, IL-4, IL-10, IFN- $\gamma /$ IL-12, IFN- $\gamma$ e IL-10/IL12 foram genotipados através da reação de PCR.

Para realizar a genotipagem dos camundongos deficientes e duplo deficientes em citocinas Th1/Th2, como IL-12, IFN- $\gamma$, IL-10 IFN- $\gamma /$ IL-12, IL-4 e IL-10/IL-12, foi extraído DNA da cauda dos camundongos descritos acima. Utilizamos PCR, na qual eram adicionados 100ng de DNA, tampão taq DNA polymerase (Invitrogen); 1,5 mM de MgCL2; 100mM de dNTPs; 50 ng dos primers descritos a seguir e 1,25U Taq Dna 
polymerase (Invitrogen) no volume final de $50 \mu$ l. As reações foram incubadas em 40 ciclos de $95^{\circ} \mathrm{C}$ por 1 minuto, $50^{\circ} \mathrm{C}$ por 1 minuto e $75^{\circ} \mathrm{C}$ por 30 s e 5 minutos a $72^{\circ} \mathrm{C}$. Os produtos foram novamente analisados após a migração eletroforética em gel de agarose 1\%, seguida por coloração com brometo de etídio.

Para a realização dos PCR, vários primers foram utilizados, a saber: IL-12: Primer 457: 5’ AGT GAA CCT CAC CTG TGA CAC G 3', Primer 458: 5' TCT TTG CAC CAG CCA TGA GC 3', Primer 13: 5' CTT GGG TGG AGA GgC TAT TC 3' , Primer 14: 5' AGG TGA GAT GAC AGG AGA TC 3'. IFNg; Primer 126: 5' AGA AGT AAG TGG AAG GGC CCA GAA G 3', Primer 127: 5' AGG GAA ACT GGG AGA GGA GAA ATA T 3', Primer 128: 5' TCA GCG CAG GGG CGC CCG GTT CTT T 3', Primer 129: 5' ATC GAC AAG ACC GGC TTC CAT CCG A 3'. IL-4; oIMR077 5'GCA CAG AGC TAT TGA TGG GTC3', oIMR78 5’GCT GTG AGG ACG TTT GGC 3', oIMRO79 5'TCA GGA CAT AGC GTT GGC3'; IL-10 5'GTG GGT GCA GTT ATT GTC TTC CCG3', 5'GCC TTC AGT ATA AAA GGG GGA CC3', 5'CCT GCG TGC AAT CCA TCT TG3'.

\subsubsection{Citometria de Fluxo para verificação da depleção e reconstitutição dos animais com transferência adotiva de medula óssea}

Os linfonodos e baço foram coletados para análise de animais reconstituídos com medula óssea após seis semanas e preparados para citometria. Cada órgão foi macerado separadamente em $5 \mathrm{~mL}$ de meio de cultura celular RPMI (Sigma, USA). A suspensão celular foi colocada em tubos Falcon de 15 mL novos em um fluxo lâminar. Esses tubos foram centrifugados a $1700 \mathrm{rpm}$, por 6 minutos, e o sobrenadante foi descartado. As células foram incubadas com $1 \mathrm{~mL}$ de ACK (solução de lise eritrocitária: NH4Cl - cloreto de amônio 0,15M; KHCO3 - bicarbonato de potássio 1mM; Na2EDTA - EDTA sódico 
0,1mM; pH 7.2-7.4), por 10 minutos. Posteriormente, lavou-se as células com $9 \mathrm{~mL}$ de R10 (RPMI contendo $10 \%$ de soro fetal bovino). Após mais uma lavagem com 10 mL de R10, ressuspendeu-se o pellet em $1 \mathrm{~mL}$ de $\mathrm{R} 10$ e as células foram diluídas e coradas com Azul de Tripan (Trypan Blue, Sigma, St. Louis. USA). As células vivas foram contadas na câmara de Neubauer $(0,0025 \mathrm{~mm} 2$, Reichert, Buffalo,USA). Para a marcação, 1 milhão/células vivas foram adicionadas em tubos eppendorf e mantidas no gelo. A mistura de anticorpos monoclonais estipulada para cada grupo (diluição 1:100 da solução original) foi adicionada aos tubos, a saber: anti-CD4 TC, anti-CD8PE, antiB220 e anti-CD3, marcados com FITC (do inglês fluorescein isothiocyanate), PE (do inglês phycoetrinin) ambos conjugados com FITC (ambos BD Pharmigen, San Diego, USA). Os tubos controle não continham anticorpos e a incubação com o anticorpo foi feita durante 30 minutos a $4^{\circ} \mathrm{C}$. As células foram analisadas em citômetro de fluxo (FACS calibur-Becton Dickinson), de acordo com a intensidade de fluorescência dos anticorpos monoclonais (FL1, FL2 ou FL3), e todos os dados obtidos foram analisados com o software CELLQUEST (Becton Dickinson).

\subsection{Ensaio Bioplex}

Os soros coletados para análise no Bioplex foram congelados a $-80{ }^{\circ} \mathrm{C}$ até o momento de uso. O painel usado foi o Mouse Th1/Th2 (Bio Rad, Hercules, CA), analisando as citocinas IL-2, IL-4, IL-5, IL-10, IL-12 (p40), IL-12 (p70), GM-CSF (Fator estimulador de colônias de macófagos e granulócitos), IFN-gamma, TNF-alpha (Fator de Necrose Tumoral), KC (Quimiocina derevida de queratinócitos, Chamada Il-8 em camundongos), IL-6, Rantes, IL-1 alpha, IL-1 beta, MIP-1 alpha (Proteína inflamatória macrofágica) , IL-3, IL-17, VEGF (Fator de Crescimento endotelial vascular) e G-CSF (Fator estimulador de colônias de granulócitos), mas nem todas citocinas foram utilizadas nessa tese, pois há uma presença grande de citocinas e apenas as mais relevantes foram utilizadas 
na tese e os resultados foram apresentado em forma de tabela, as citocinas analizadas foram KC, IL-6 e IL-4. O ensaio foi desenvolvido de acordo com o protocólo do fabricante. Brevemente, $20 \mu \mathrm{L}$ do soro dos animais foi diluído em $60 \mu \mathrm{L}$ "Bioplex Mouse Serum Diluent" (Bio Rad, Hercules, CA). O filtro da placa multiwell 96 foi lavado com Bioplex Assay Buffer (Bio Rad). Em seguida, foram adicionados as beads conjugados com anticorpos anti-citocinas, lavados com Bioplex Wash Buffer, sendo posteriormente adicionados os soros diluídos. Seguido de uma incubação de 2 horas, a placa foi novamente lavada com Bioplex Wash Buffer, sendo então adicionado a cada well o anticorpo biotinilado de detecção para um epítopo diferente da citocina, formando então um sanduíche de anticorpos, incubado por 1 hora. Após esse período, estreptavidina conjugada com PE, que se liga ao anitcorpo biotinilado, incubação por 30 minutos. Novas lavagens foram realizadas com Bioplex Wash Buffer, e as beads foram resuspensas com Bioplex Assay Buffer e analisados no Bioplex 200 Suspension Array system/Luminex (Bio Rad, Hercules, CA) através dos Software Bio-Plex Manager, versão 4.1 (Bio Rad, Hercules, CA). Os dados observados são referentes à no mínimo 100 beads por citocina.

Foram analizadas em todos os grupos dos animais nocautes normais sem serem submetidos ao clampeamento dos pedículos renais à presença de todas as citocinas citada acima, a concentração das citocinas no soro desses animais normais foram de 0-5 Pg/mL, sendo assim, os animais sham que sofreram apenas o processo de dissecamento do pedículo renal não foram estudadas a concentração das citocinas no soros desses animais, pois os resultados estudados nos animais sham são sempre semelhantes aos resultados encontrado nos animais normais.

Este ensaio foi realizado pela aluna de doutorado orientanda do professor Niels Olsen (Dra. Patricia Semedo), apenas o método cirurgio e coleta dos soros foram realizados por mim. 


\subsection{Análise Estatística}

Os resultados foram apresentados na forma de média e desvio padrão ou mediana e faixa de variação dos valores, caso as variáveis apresentassem uma distribuição gaussiana ou não. As diferenças foram consideradas estatisticamente significantes quando o valor de p era menor que 0,05. Na comparação intragrupo, as variáveis foram avaliadas através da análise de variância ANOVA unicaudal pelo teste de Kruskal-Wallis e, quando houve diferença, foram comparadas entre si pelo teste de Dunn. Na comparação entre os grupos, a análise das variáveis entre os diferentes pontos de tempo do estudo foi feita através do teste de Mann-Whitney ou t de student.

Foi utilizado o programa Sigma Stat for Windows 2.0, 1999 (SSPS Inc., Chicago, EUA) para todas as análises realizadas.

O teste de Pearson foi usado para verificar a significância estatística na análise de correlação. E para análise de correlação, os valores das expressões dos genes foram logaritmizados. 
4. Resultados 


\section{Parte I.}

Resultados dos estudos com animais nocautes para as citocinas do perfil Th1 (IL-12, IFN- $\gamma$ e IFN- $\gamma /$ IL-12), do perfil Th2 (IL-4 e IL-10) e para a IL-10/IL-12 


\subsection{Peso}

A lesão de I/R acarreta uma perda de água e gera um estado de catabolismo nos animais, que podem ser quantificados indiretamente pela perda de peso. Acreditamos que exista uma correlação direta entre o percentual de perda de peso e a gravidade da lesão renal. Para tanto, calculamos um delta de perda de peso, entre o valor inicial e o obtido no dia do sacrifício.

De uma forma geral, os animais perderam mais peso quando submetidos ao procedimento cirúrgico com a ligadura dos pedículos renais. Os animais selvagens submetidos ao procedimento sham perderam o mesmo peso que os animais nocautes para todas as citocinas estudadas $(\mathrm{p}<0,05)$. Dentre os animais nocautes sham, os deficientes para IFN- $\gamma$ apresentaram a maior perda de peso e os deficientes para IFN- $\gamma /$ IL-12, a menor (Figura 4.1).

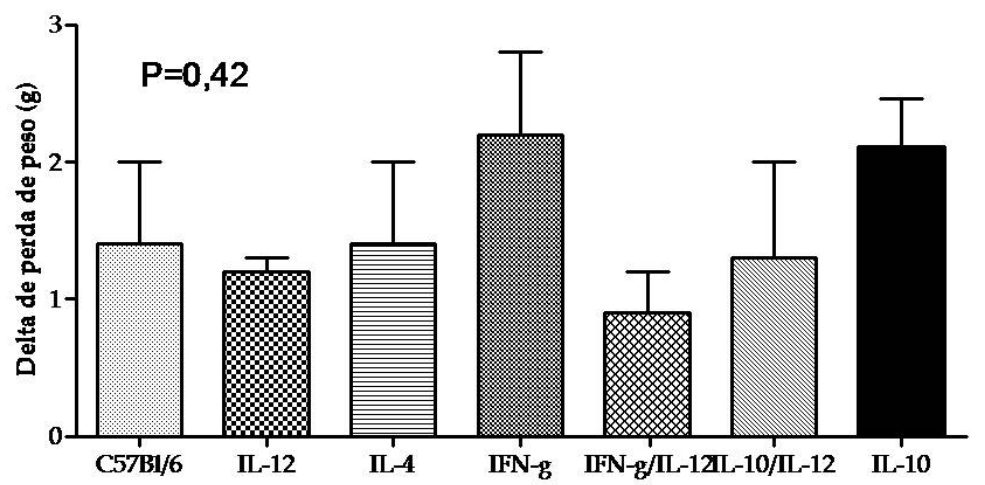

Figura 4.1.: Delta da perda de peso nos animais nocautes e nos animais selvagens submetidos somente ao procedimento cirúrgico sem ligadura do pedículo renal (Sham). Nâo houve significância estatistica entre os valores obtidos (ANOVA, $N=3$ ), $P=0$, 42.

Após a reperfusão, os animais selvagens apresentaram uma perda significativa de peso quando comparados aos mesmos animais shams $(\mathrm{p}=0,031)$ (Figura 4.2).

Investigamos também se a ausência de alguma citocina implicava uma maior perda de peso, quando os animais eram submetidos à lesão de $\mathrm{I} / \mathrm{R}$, em relação aos animais 
(A)

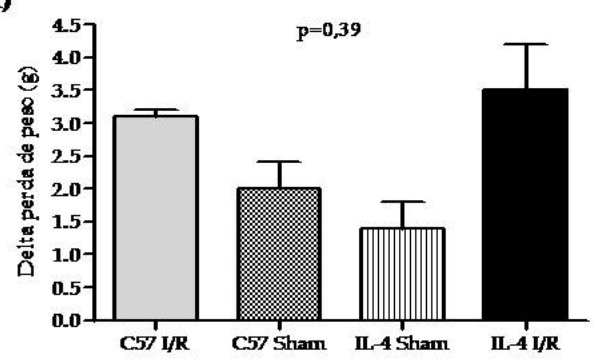

(C)

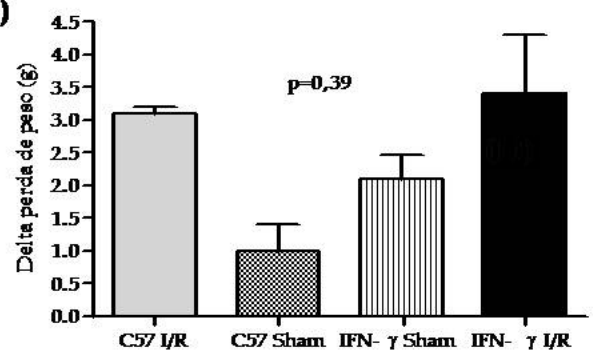

(E)

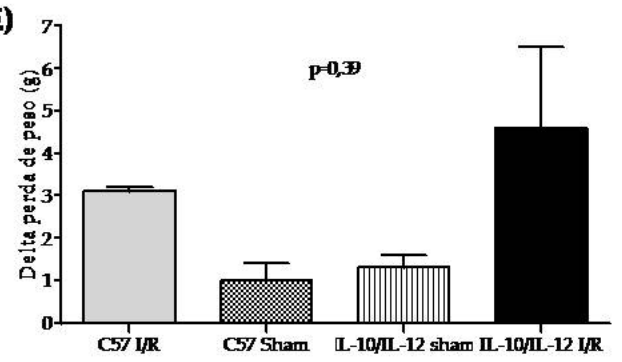

(B)

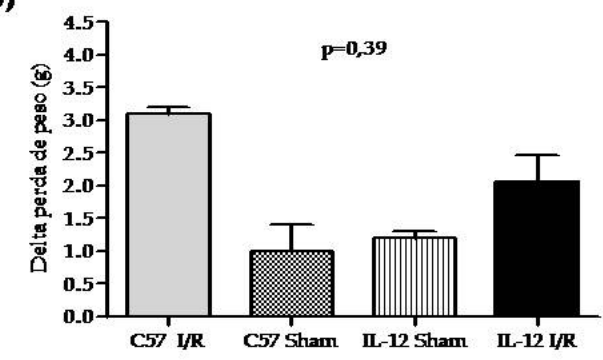

(D)

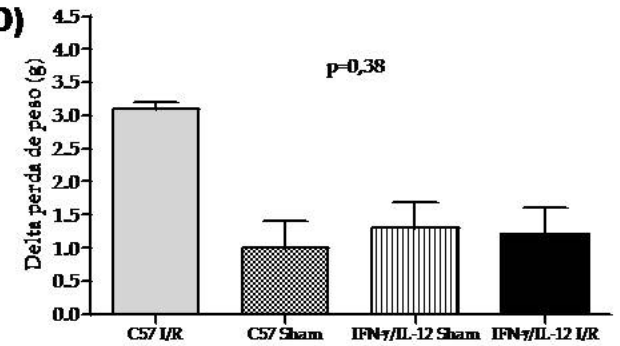

(F)

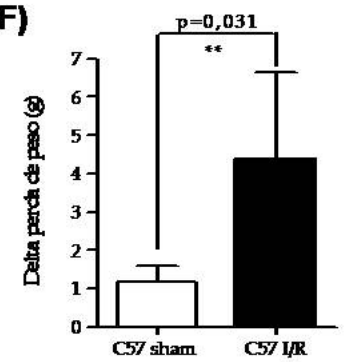

Figura 4.2.: Delta da perda de peso entre animais sham e submetidos à lesão de $I / R$ renal após 24 de reperfusão. (**) Houve significância estatística na comparação entre os animais selvagens do grupos sham e submetidos à lesão de $I / R . N=4-6$ para os grupos $I / R$ e $N=3$ para os grupos Sham. 
selvagens, possivelmente denotando uma maior gravidade da lesão renal. Desta forma isolada, todos os grupos foram comparados ao grupo selvagem $(\mathrm{C} 57 \mathrm{Bl} / 6)$. Os animais nocautes para IL-4, IL-12, IL-10, IFN- $\gamma$ e IL-10/IL12 apresentaram perda de peso similar à observada nos animais selvagens, sem diferenças significativas $(p=0,39, p=0,39, p=0,39$ $\mathrm{p}=0,38$ e $\mathrm{p}=0,39$, respectivamente) (Figura 4.2). Porém, houve menor perda de peso sem diferenças significativas nos animais nocautes para IL-12 e o duplo-nocautes em IFN-g/IL-12 submetidos à lesão de I/R em relação ao grupo selvagem $(p=0,39)$ (Figura $4.2)$.

\subsection{Função renal}

Utilizamos a dosagem sérica de creatinina como método de avaliação da função renal. Amostras de soro colhidas com 24 horas de reperfusão foram usadas para o ensaio.

Os valores creatinina nos camundongos não manipulados (normais) selvagens foram semelhantes aos dos camundongos deficientes em IL-4, IL-12, IL-10/IL-12, IFN- $\gamma /$ IL-12 e IFN- $\gamma$, todos com valores menores que o valor normal de referência $0,5 \mathrm{mg} / \mathrm{dL}$. Por isso, os valores dos animais normais não foram discriminados aqui. Da mesma forma, os animais submetidos ao procedimento cirúrgico, sem a ligadura dos pedículos renais, apresentaram níveis de creatinina sérica semelhantes entre si ( $\mathrm{p}=0,41$, Figura 4.3) e também semelhantes aos valores normais de cada linhagem.

Entretanto, uma vez tendo sido submetido à lesão de I/R, os animais apresentaram graus variados de lesão renal. Os animais selvagens apresentaram uma elevação da creatinina sérica $(1,6 \pm 0,6 \mathrm{mg} / \mathrm{dL})$ superior à observada nos animais nocautes para IL$12(0,6 \pm 0,04 \mathrm{mg} / \mathrm{dL}, \mathrm{p}=0,036)$ e para IFN- $\gamma / \mathrm{IL}-12(0,4 \pm 0,08 \mathrm{mg} / \mathrm{dL}, \mathrm{p}=0,036)$.

Não houve diferenças significativas em relação aos outros grupos estudados.

Interessantemente, os animais nocautes para as citocinas IL-4 (1,42 $\pm 0,33 \mathrm{mg} / \mathrm{dL})$, 


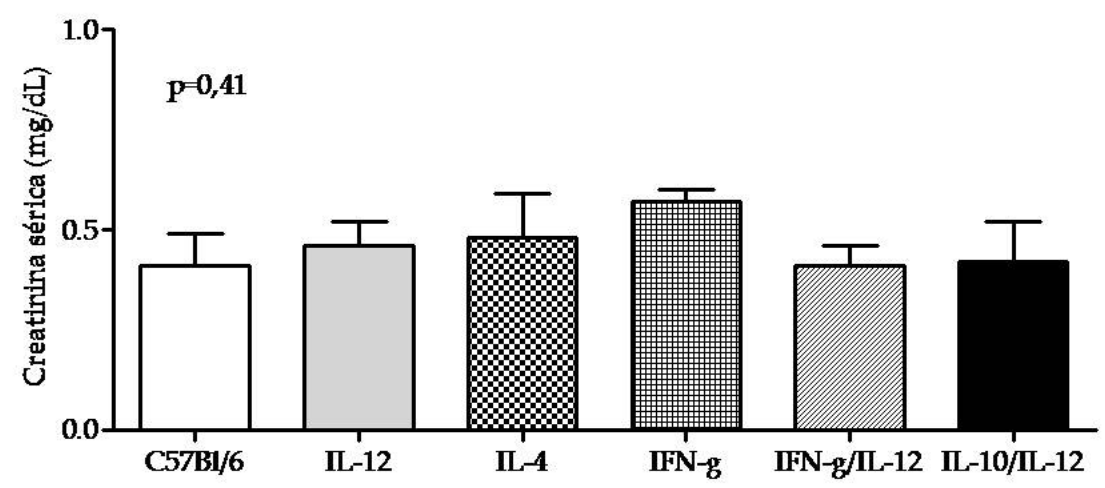

Figura 4.3.: Função renal nos animais nocautes e nos animais selvagens sham-operados. Não houve significância estatística entre os valores obtidos ( $A N O V A, N=3, p=0,41$ ).

IFN- $\gamma(1,98 \pm 0,38 \mathrm{mg} / \mathrm{dL})$ e IL-10/IL-12 $(1,97 \pm 0,10 \mathrm{mg} / \mathrm{dL})$ apresentaram níveis semelhantes ao controle selvagem $(1,6 \pm 0,6 \mathrm{mg} / \mathrm{dL})$, ilustrado na figura 4.4 . 
(a)

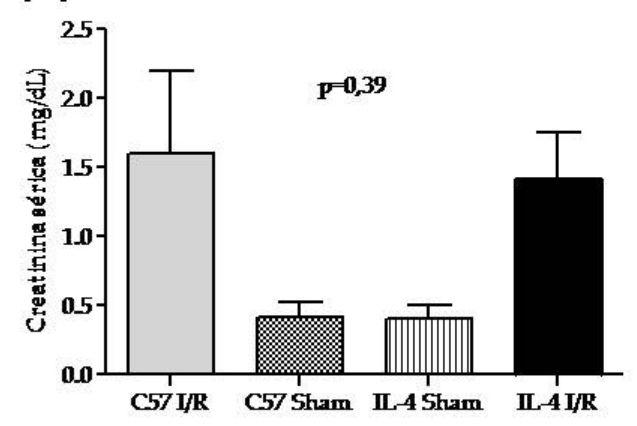

(c)

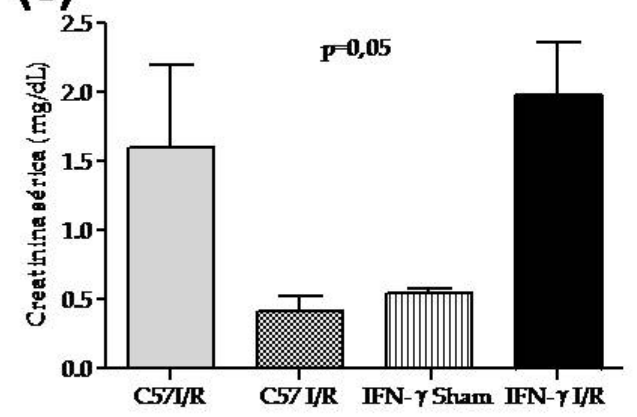

(b)

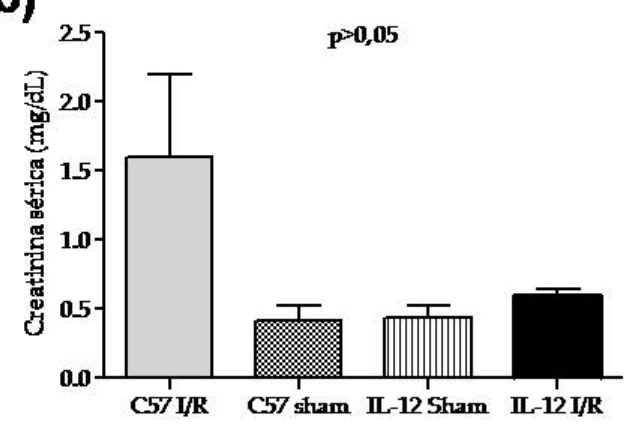

(d)

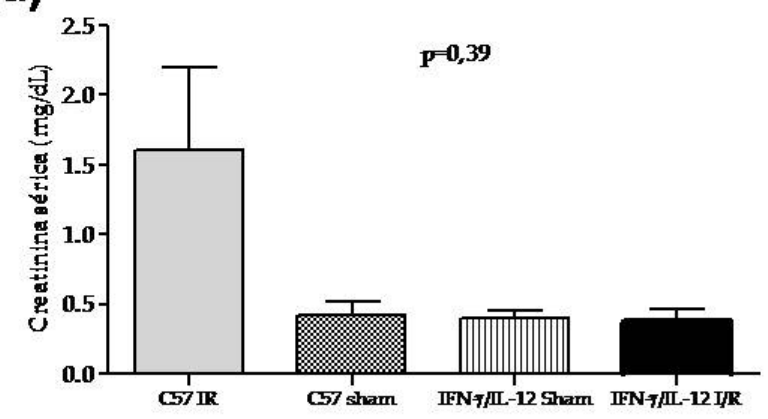

(e)

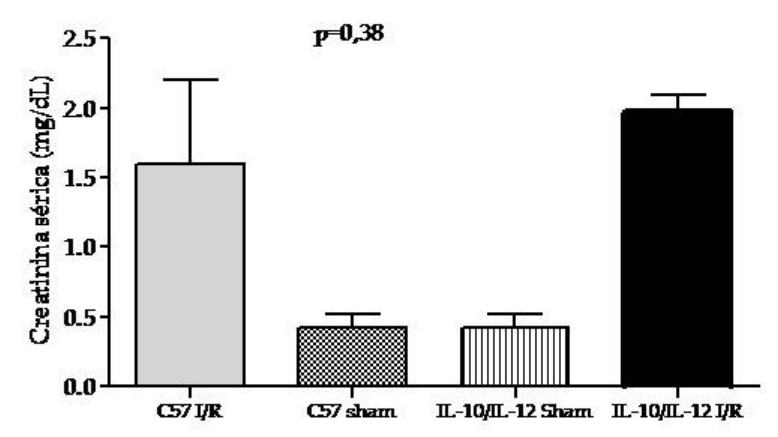

Figura 4.4.: Função renal após 24 horas de reperfusão nos animais nocautes para IL-4 (a), $I L-12(b), I F N-\gamma(c), I F N-\gamma / I L-12$ (d) e IL-10/IL-12 (e) em comparação com os animais selvagens. Nâo houve diferença estatistica entre os valores obtidos nos animais estudados ( $A N O V A, N=3$ animais sham e $N=4-6$ animais $I / R$ ). 


\subsection{Análise morfométrica: Necrose Tubular (NT) e Regeneração tubular (RT)}

Nesta análise, avaliamos a percentagem de área da medula externa comprometida por NT e em processo de regeneração (RT) em relação à área total estudada.

Os animais normais e os animais shams dos grupos selvagem e nocautes não apresentaram NT e, portanto, estes dados não foram discriminados aqui.

Inicialmente, analisando todos os grupos, observamos que os animais nocautes para IL-10/IL-12, IL-4 e IFN- $\gamma$ apresentaram níveis de NT semelhantes aos quantificados nos animais selvagens. Especificamente, os camundongos deficientes em IL-10/IL-12 apresentaram mais $\mathrm{NT}(46,2 \%, 3,4-73,2)$, semelhante estatisticamente àquela quantificada nos camundongos selvagens $(41 \%, 18-67,8)$. Os valores obtidos na quantificação da NT nos animais selvagens foram significativamente diferentes $(p<0,001)$ dos aferidos nos animais nocautes para IL-12/IFN- $\gamma(0 \%, 0-13,5)$, IL-12 $(0 \%, 0-34,6)$, IFN- $\gamma(33,1 \%$, $5,1-60,3)$ e IL-4 $(28,3 \%, 20-40,7)$ (Figura 4.5).

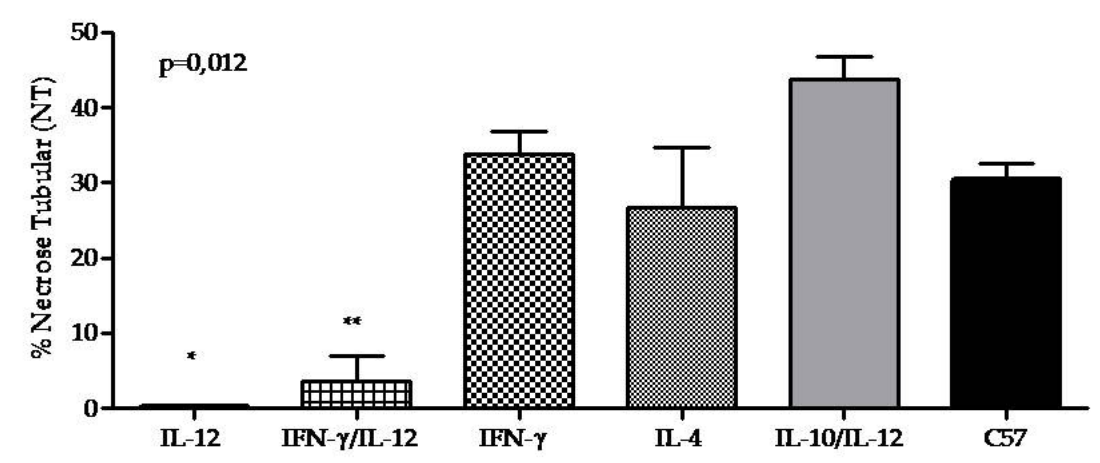

Figura 4.5.: Valores médios da percentagem de necrose tubular (NT) na medula externa dos animais selvagens e nocautes submetidos a lesão de I/R. (*) (**) Houve significância estatística somente entre os valores encontrados nos animais selvagens e os quantificados nos animais nocautes para IL-12 e IFN- $\gamma / I L-12, p=0,012$. ANOVA, $N=4-6$.

As alterações morfológicas características de RT na medula externa estiveram 
ausentes em todos os animais dos grupos sham e normal, tanto nos grupos selvagem como nos deficientes nas citocinas estudadas.

Nos animais nocautes para IFN- $\gamma$ submetidos à lesão de $\mathrm{I} / \mathrm{R}$, o percentual médio de RT $(4,2 \%, 0-22,6)$ foi significativamente maior $(\mathrm{p}<0,001)$ do que o observado nos animais selvagens $(0 \%, 0-23,3)$, IL-4 (0\%, 0-0), IL-10/IL-12 (0\%, 0-0,5) e IFN- $\gamma /$ IL-12 (0\%, 0-0, ilustrado na figura 4.6).

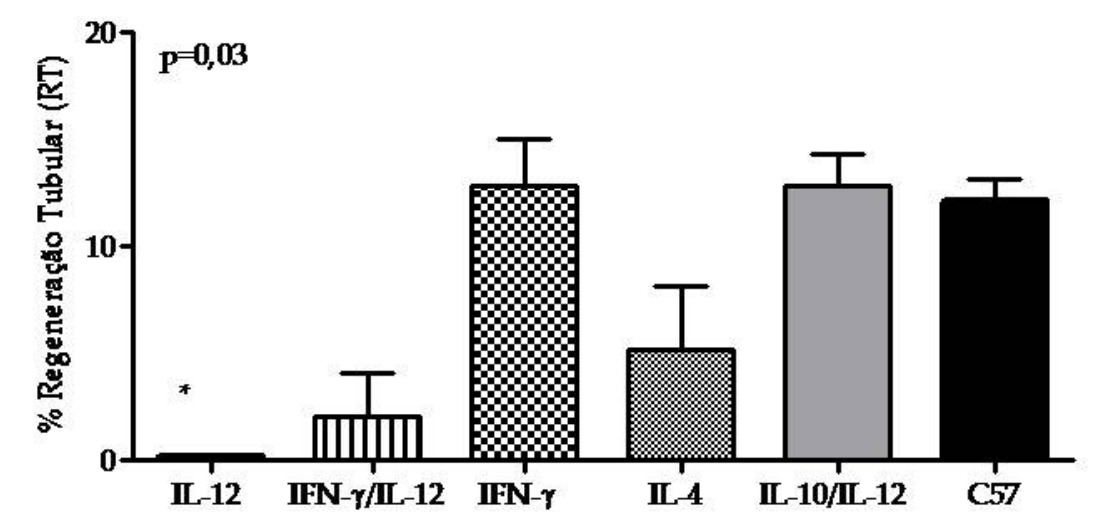

Figura 4.6.: Valores médios da percentagem de regeneração tubular (RT) na medula externa dos animais selvagens e os nocautes submetidos a lesão de $I / R$. Os animais nocautes IFN- $\gamma$ apresentaram maior regeneração tubular. (*) Houve diferença significativa entre os valores encontrados nos animais selvagens e os quantificados nos animais nocautes para IFN- $\gamma$. ANOVA, $N=4-6 . P=0,03$.

Os cortes histológicos de rins corados com hematoxilina-eosina, que ilustram os variados graus de NT nos animais selvagens, nocautes e duplo-nocautes submetidos à lesão de I/R, estão discriminados na Figura 4.7. 

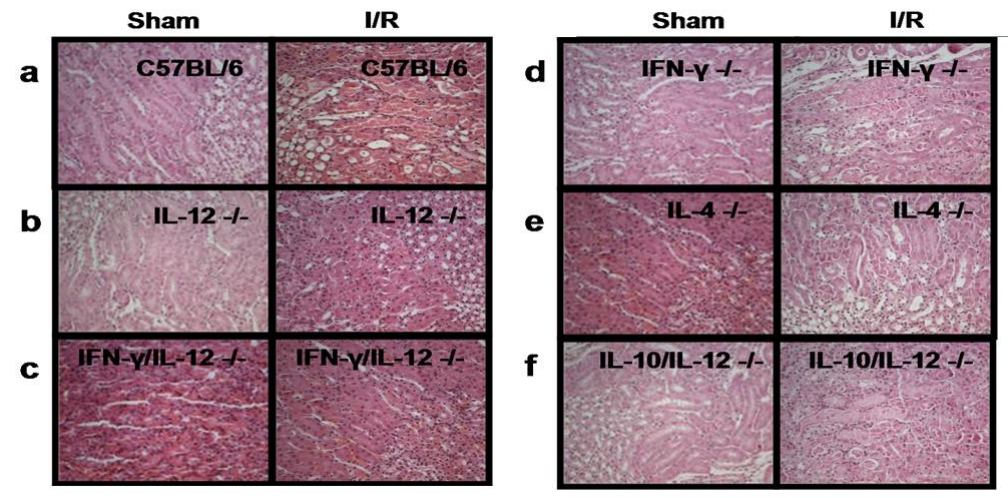

Figura 4.7.: Fotos ilustrativas de corte histológico corado com HËE, mostrando alteraçôes compativeis com Necrose Tubular (NT) e Regeneração Tubular (RT) dos grupos dos animais Sham e submetidos à lesão de $I / R$ com 24 horas de reperfusão: Controle

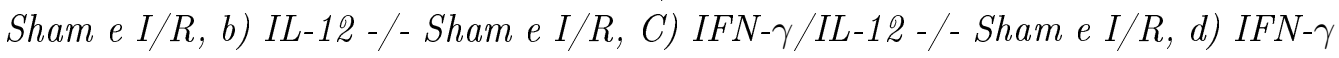
-/- Sham e I/R, e) IL-4-/- sham e I/R e f) IL-10/IL-12 -/- sham e I/R. Objetiva com aumento de 40X. $N=4-6$.

\subsection{Resultados animais nocaute para citocina IL10}

Após a qualificação do meu mestrado, resolvemos estudar mais um grupo de animais nocautes para uma citocina de padrão Th2 (a IL-10). Entretanto, neste período no laboratório, o método de dosagem de creatinina sérica não estava funcionando adequadamente e, por isso, utilizamos o método de dosagem de uréia sérica para avaliar a função renal nesses animais. Os resultados obtidos com estes animais foram comparados às uréias aferidas nos animais selvagens.

Os animais nocautes para citocina IL-10, submetidos à lesão de I/R renal em 24 horas, apresentaram uma maior perda de peso $(\mathrm{P}=0,36$, Figura 4.8) e maiores níveis de uréia sérica $(197 \pm 1,6 \mathrm{mg} / \mathrm{dL}, \mathrm{p}=0,37)$ quando comparados com os animais-controle selvagens também submetidos à lesão de I/R (190土4,9 mg/dL, ilustrado figura 4.9). 


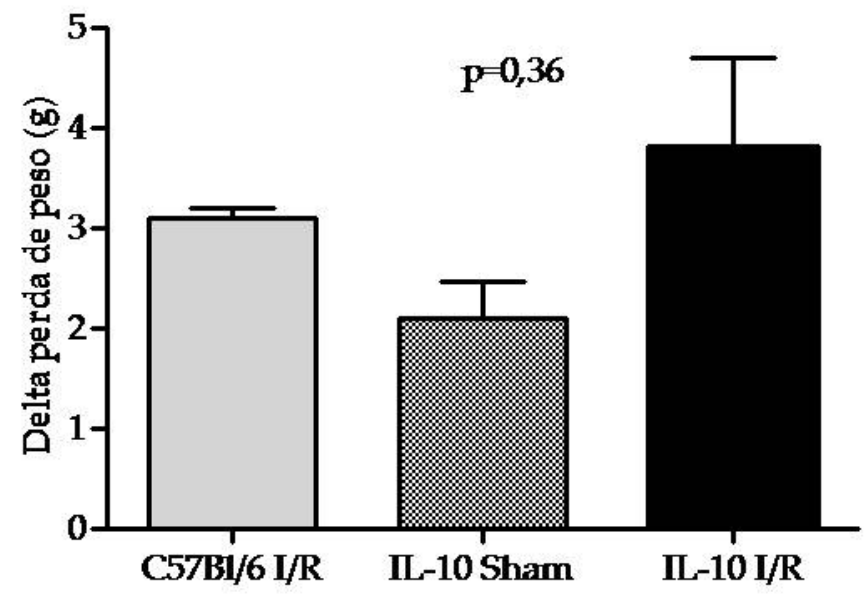

Figura 4.8.: Delta da perda de peso entre animais IL-10 nocautes sham e submetidos à lesão de $I / R$ renal em comparação com os animais selvagens. Não houve diferença estatistica entre os grupos ( $A N O V A, N=3$ animais Sham e $N=4-6$ animais $I / R$, $P=0,36)$.

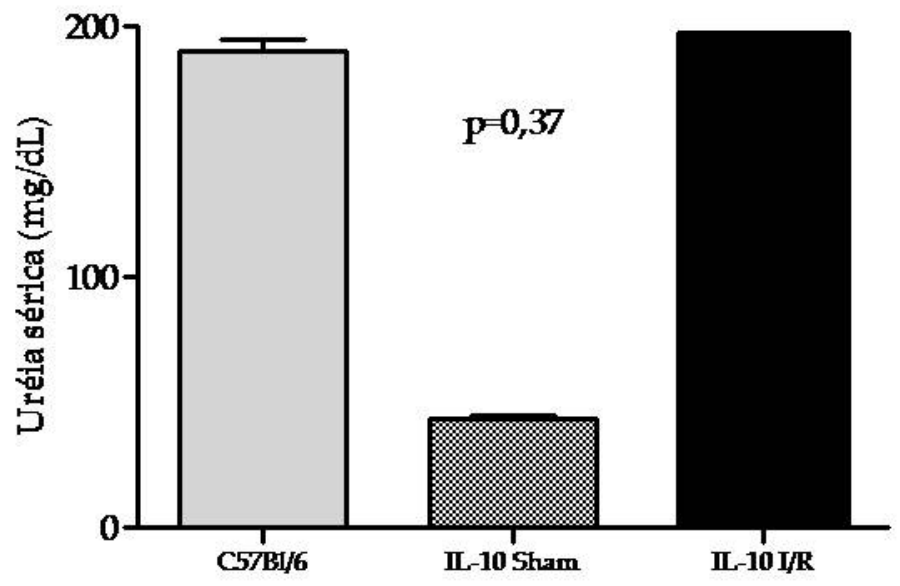

Figura 4.9.: Função renal após 24 horasde reperfusão nos animais nocautes para citocina IL-10 em comparação com os animais selvagens. Não houve diferença estatística entre os valores obtidos nos animais selvagens e nos nocautes para $I L-10$ (ANOVA, N=3 animais Sham, $N=4$ animais $I / R, P=0,37)$.

Estudamos as percentagens de NT e RT nestes animais. Os resultados demonstraram que os animais nocautes para citocina IL-10 submetidos à lesão de I/R apresentaram significativamente maior percentagem de NT (56\%, 48-65) quando comparados ao 
animal-controle selvagem $(41 \%, 18-67,8), 24$ horas após a reperfusão $(\mathrm{p}=0,005)$ (ilustrado na Figura 4.10). Já a percentagem de RT nesses animais $(0,9 \% 0-1,7)$ foi significativamente menor do que a observada no controles selvagens $(0 \% 0-23,3, \mathrm{p}=0,003)$, como ilustrado na Figura 4.11.

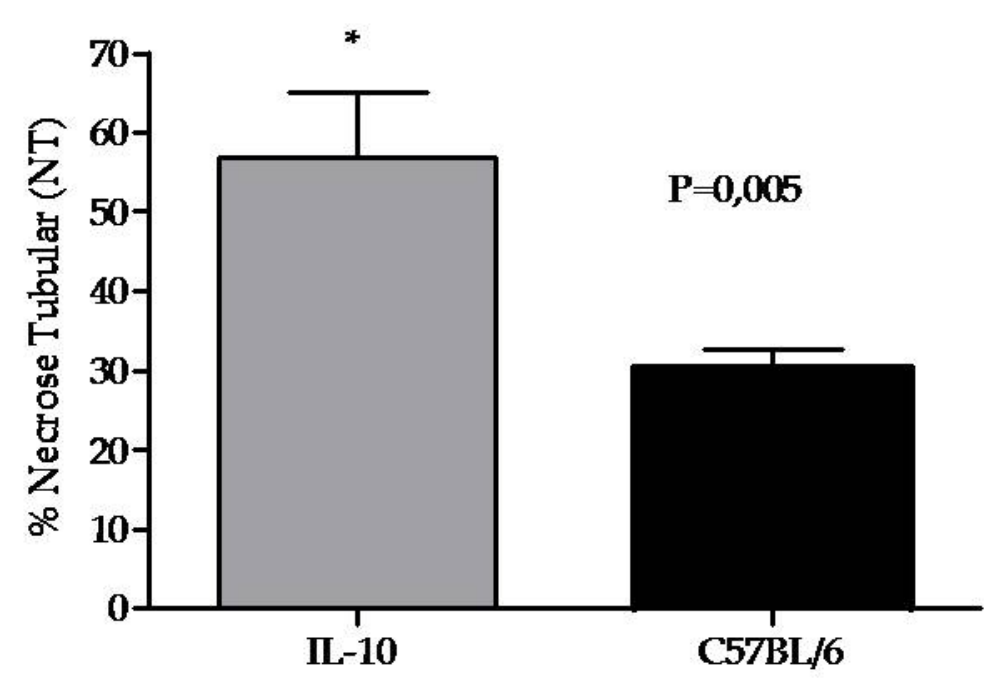

Figura 4.10.: Valores médios da percentagem de Necrose Tubular (NT) na medula externa dos animais selvagens e $I L-10$ nocautes submetidos a lesão de $I / R .\left(^{*}\right)$ Houve diferença estatistica entre os valores (T-test, $N=4-6, P=0,005$ ). 


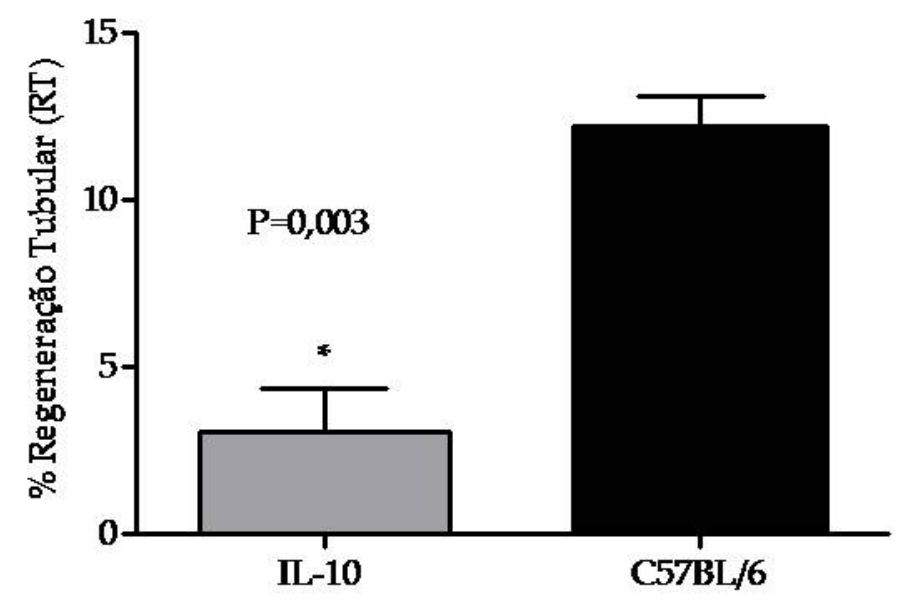

Figura 4.11.: Valores médios da percentagem de Regeneração tubular (RT) na medula externa dos animais selvagens e nocautes para IL-10 submetidos a lesão de $I / R$. (*) Houve diferença estatística entre os valores obtidos (T-test. $N=34-6$ animais $I / R, P=0,003$.).

Os cortes histológicos de rins corados com hematoxilina-eosina, que ilustram os variados graus de NT nos animais selvagens e nocaute para citocina IL-10 submetidos à lesão de I/R, são discriminados na Figura 4.12. 


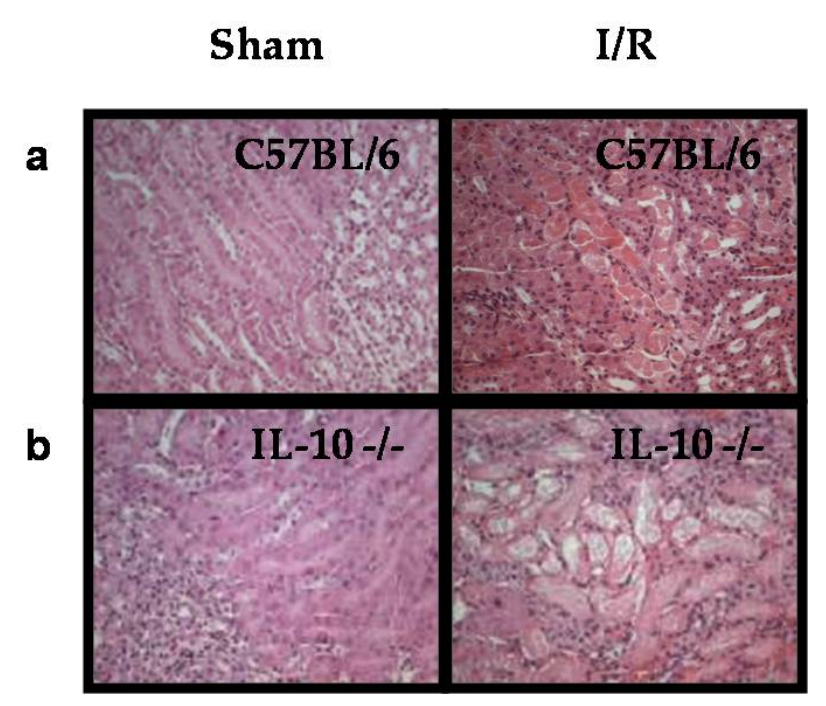

Figura 4.12.: Fotos ilustrativas de corte histológico corado com HEEE, mostrando alteraçôes compativeis com Necrose Tubular (NT) e Regeneração Tubular (RT) dos grupos dos animais sham e submetidos à lesão de $I / R$ após 24 horas de reperfusão : a) Controle Sham e $I / R$ b) IL-10 -/- sham e I/R. ANOVA. Objetiva em um aumento de $40 X$.

As alterações morfológicas características de RT na medula externa estiveram ausentes em todos os animais dos grupos sham e normal, tanto nos grupos selvagem como nos deficientes em IL-10.

\subsection{Análises dos transcritos gênicos}

A reação em cadeia da polimerase em tempo real foi empregada para amplificação dos seguintes genes: T-bet, como um fator de transcrição relacionado ao perfil Th1, GATA-3, como um fator de transcrição relacionado com o perfil Th2, IL-6, como exemplo de citocina pró-inflamatória, MCP-1, como exemplo de quimiocina pró-inflamatória, e a HO-1, como exemplo de um gene citoprotetor.

Para todas as moléculas, as análises das reações empregaram os valores obtidos nos animais selvagens não manipulados como referência, ou seja, valor igual a um. Os valores encontrados nos animais shams em todos os grupos não diferiram significativamente dos 
valores encontrados nos animais não manipulados e, portanto, estes dados não foram discriminados aqui.

\subsubsection{Transcrito gênico: T-bet}

Utilizamos o fator de transcrição T-bet como referência de uma resposta imune polarizada para o tipo Th1 [82].

A amplificação deste transcrito foi maior nos animais selvagens submetidos à lesão de I/R (Figura 4.13) em relação a todos os grupos nocautes. Porém, só observamos diferenças estatisticamente significativas na comparação com os animais nocautes para IL-4 $(\mathrm{p}=0,05)$ e IL-10/IL-12 $(\mathrm{p}=0,03)$. 
(A)

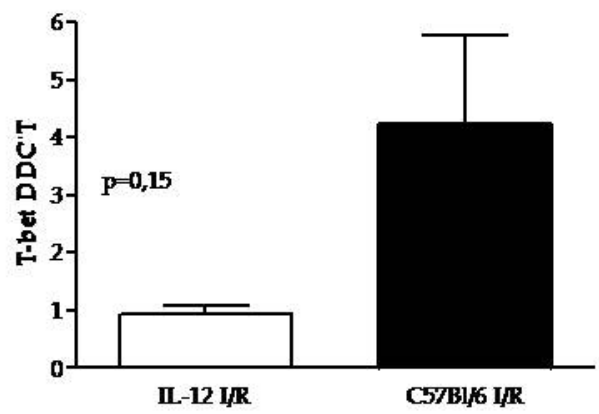

(B)

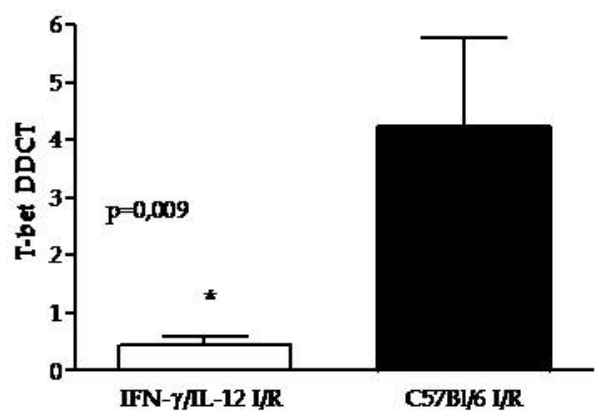

(E)

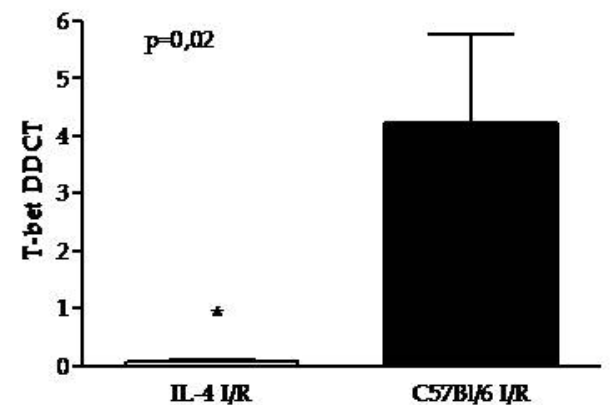

(C)

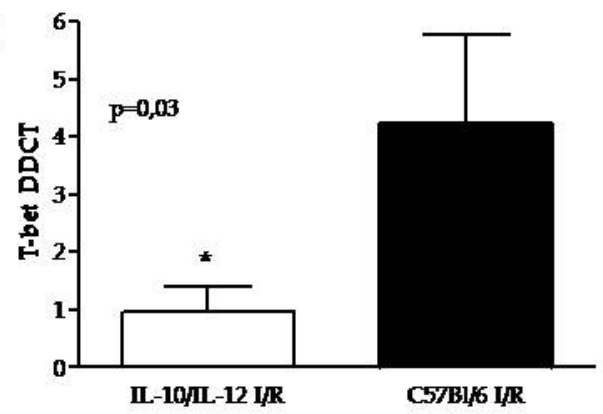

(D)

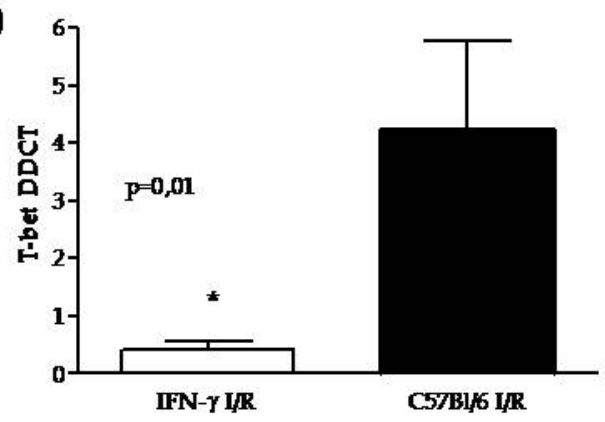

(F)

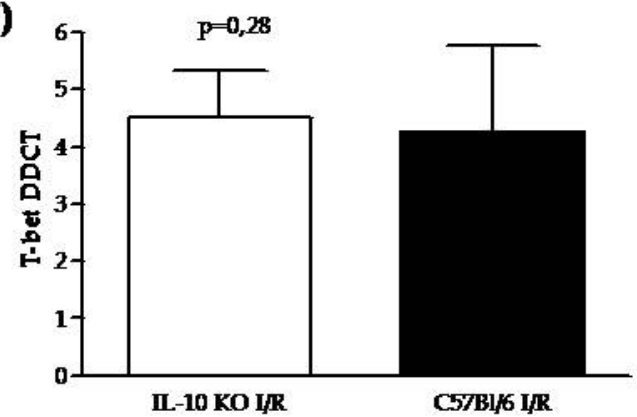

Figura 4.13.: Expressão do gene T-bet nos rins dos animais selvagens e nos nocautes de $I L$ -

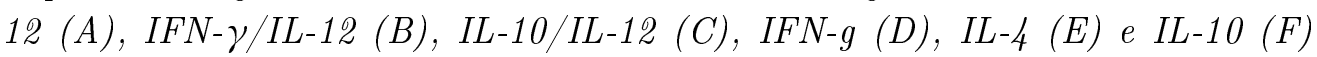
após 24 horas de reperfusão. (*) Houve significância estatística entre os valores

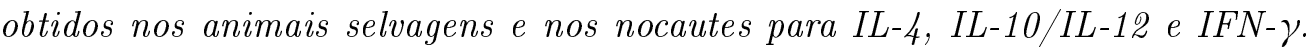
T-test, $N=4-6$.

\subsubsection{Transcrito Gênico: GATA-3}

De forma inversa, quantificamos o RNA mensageiro de GATA-3 como referência de uma resposta polarizada para Th2 [82].

A amplificação de GATA-3 foi menor, porém ele foi ainda mais expressado nos animais selvagens submetidos à lesão de I/R (Figura 4.14). Quando comparamos estes val- 
ores com os quantificados nos animais nocautes, observamos que, em todas as condições, com exceção dos animais nocautes para IFN- $\gamma$, houve uma menor expressão do transcrito, com significância estatística $(\mathrm{p}=0,003)$ (Figura 4.14).
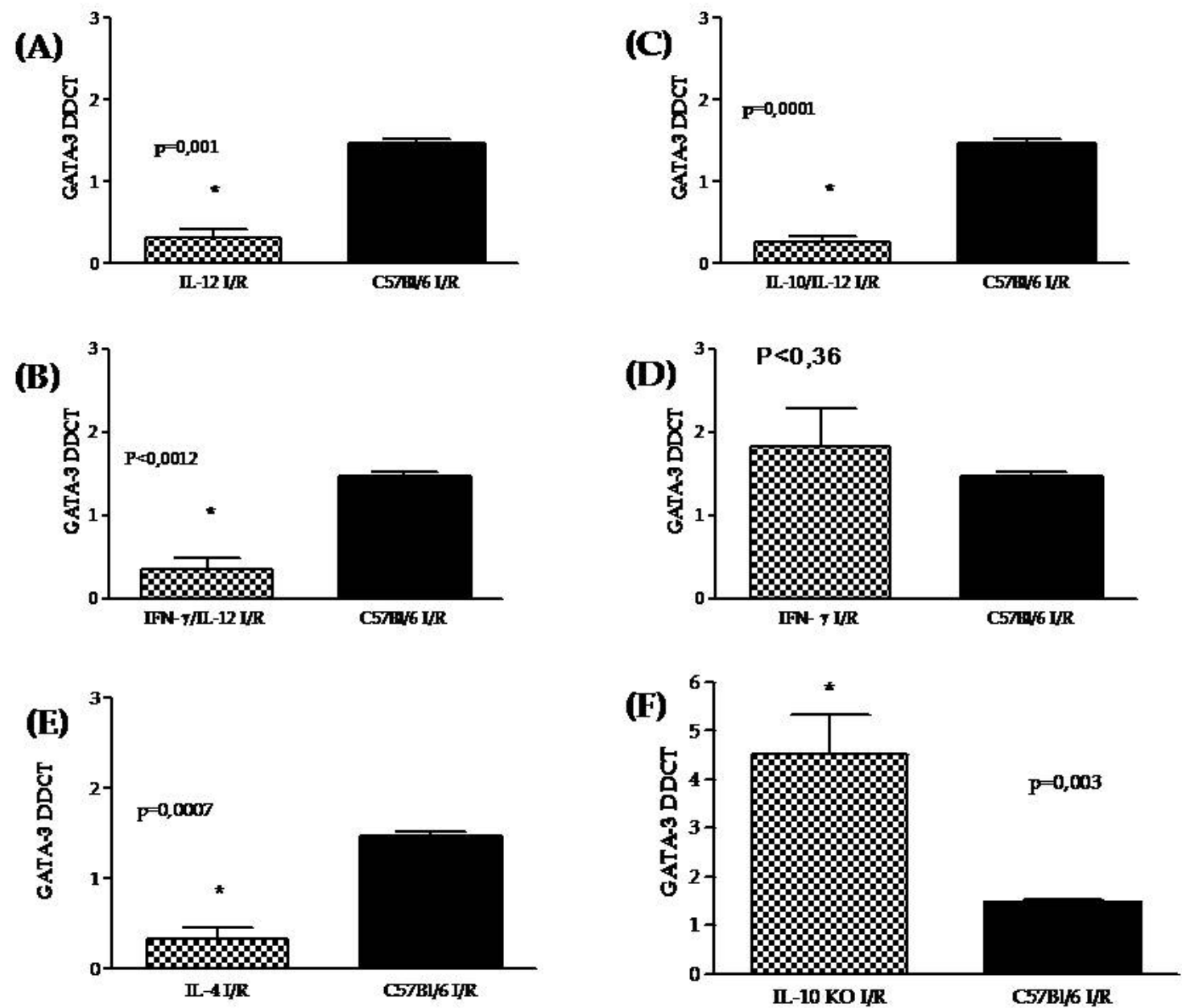

Figura 4.14.: Expressão do gene GATA-3 nos rins dos animais selvagens e nos nocautes de $I L-12(A), I F N-\gamma / I L-12(B), I L-10 / I L-12(C), I F N-\gamma(D)$ e IL-4 (E) após 24 horas de reperfusão. (*) Houve significância estatística entre os valores obtidos nos animais selvagens e nos nocautes para IL-4, IL-12, IL-10/IL-12, IL-10 e IFN- $\gamma / I L-12$, com exceção dos animais nocautes para IFN-g. T-test. $N=4-6$. 


\subsubsection{Transcrito Gênico: $M C P-1$}

Considerando a lesão de I/R como um evento inflamatório com influxo de polimorfonucleares e macrófagos, quantificamos a quimiocina MCP-1 como marcador dessa resposta.

Animais selvagens submetidos à lesão de $\mathrm{I} / \mathrm{R}$ apresentam uma significativa expressão de MCP-1 24 horas após a reperfusão (Figura 4.15). Quando comparamos estes valores com os obtidos nos animais nocautes, percebemos que os animais nocautes para as citocinas IL-4, IFN- $\gamma$, IL-10 e IL-10/IL-12 apresentavam maior expressão desse transcrito, enquanto os animais nocautes para as citocinas IL-12 e duplo-nocautes para IFN$\gamma /$ IL-12 apresentavam menor expressão de MCP-1 (respectivamente, $\mathrm{p}=0,45 \mathrm{e} \mathrm{p}=0,31$ ). Apenas os animais nocautes IFN- $\gamma$ e duplo nocaute IL-10/IL-12 apresentaram significativamente maior expressão de MCP-1 quando comparados com os animais-controle selvagens, $\mathrm{p}=0,048$ e $\mathrm{p}=0,04$. 
A)

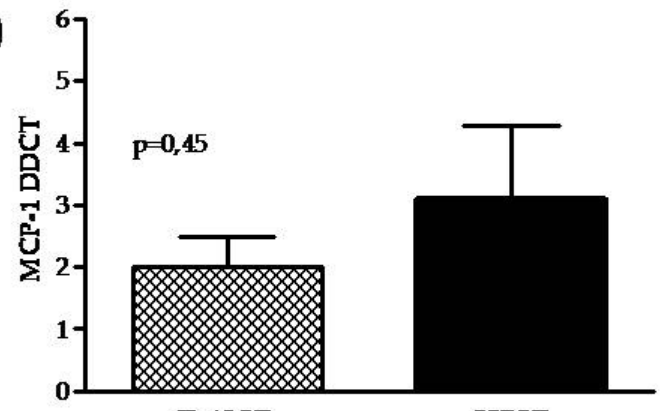

IL-12 I/R

C)

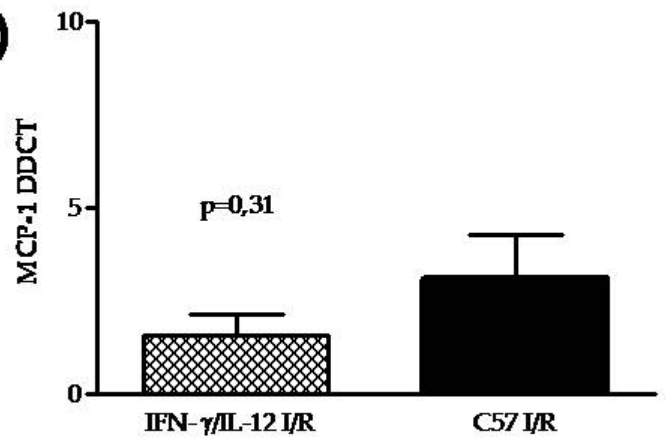

E)

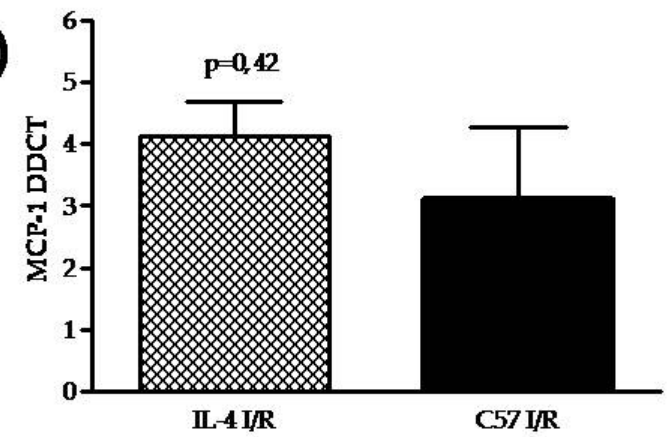

B)

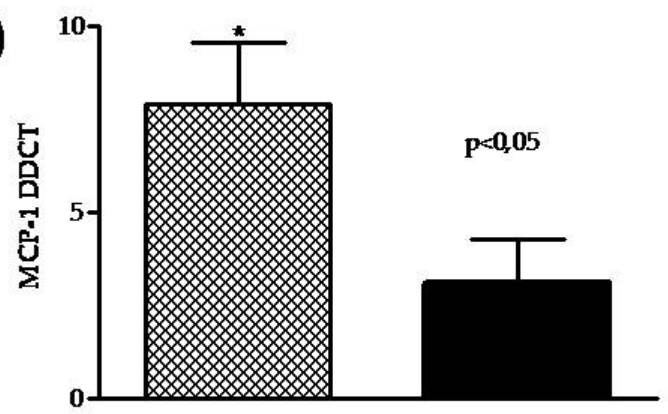

IL-10/L-12 I/R

C57I/R

D)

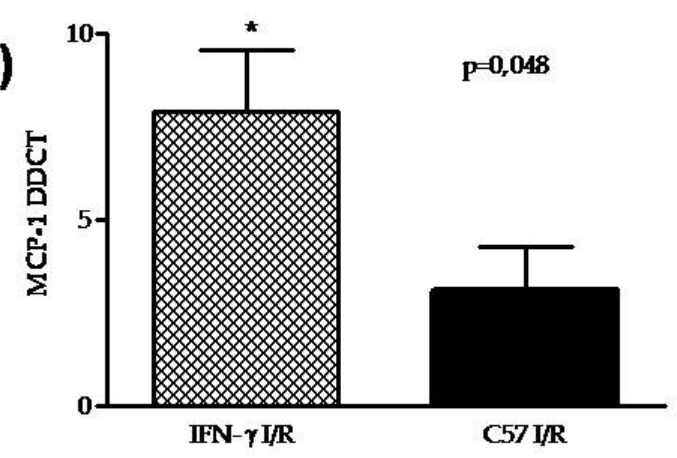

F)

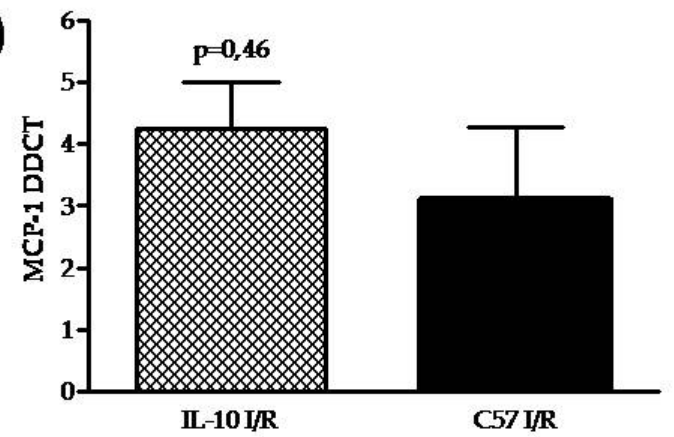

Figura 4.15.: Expressão do gene MCP-1 nos rins dos animais selvagens e nos nocautes de $I L$ -

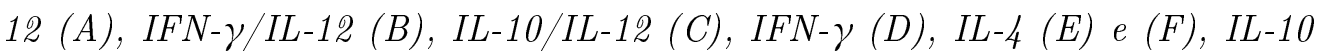
após 24 horas de reperfusão. (*) Houve significância estatística entre os valores obtidos nos animais selvagens e nos nocautes IFN- $\gamma$ e duplo-nocautes $I L-10 / I L$ 12. T-test. $N=4-6$.

\subsubsection{Transcrito Gênico: IL-6}

Estudamos também a expressão de uma segunda citocina que possui propriedades pró-inflamatórias no contexto da inflamação renal (a IL-6) [109].

Os animais selvagens submetidos à lesão de $\mathrm{I} / \mathrm{R}$ apresentaram uma elevação da 
expressão da IL-6 em relação aos animais shams e controles (Figura 4.16). De forma interessante, os animais nocautes para IL-12 apresentaram uma menor expressão significativa desta citocina $(\mathrm{p}=0,027)$.
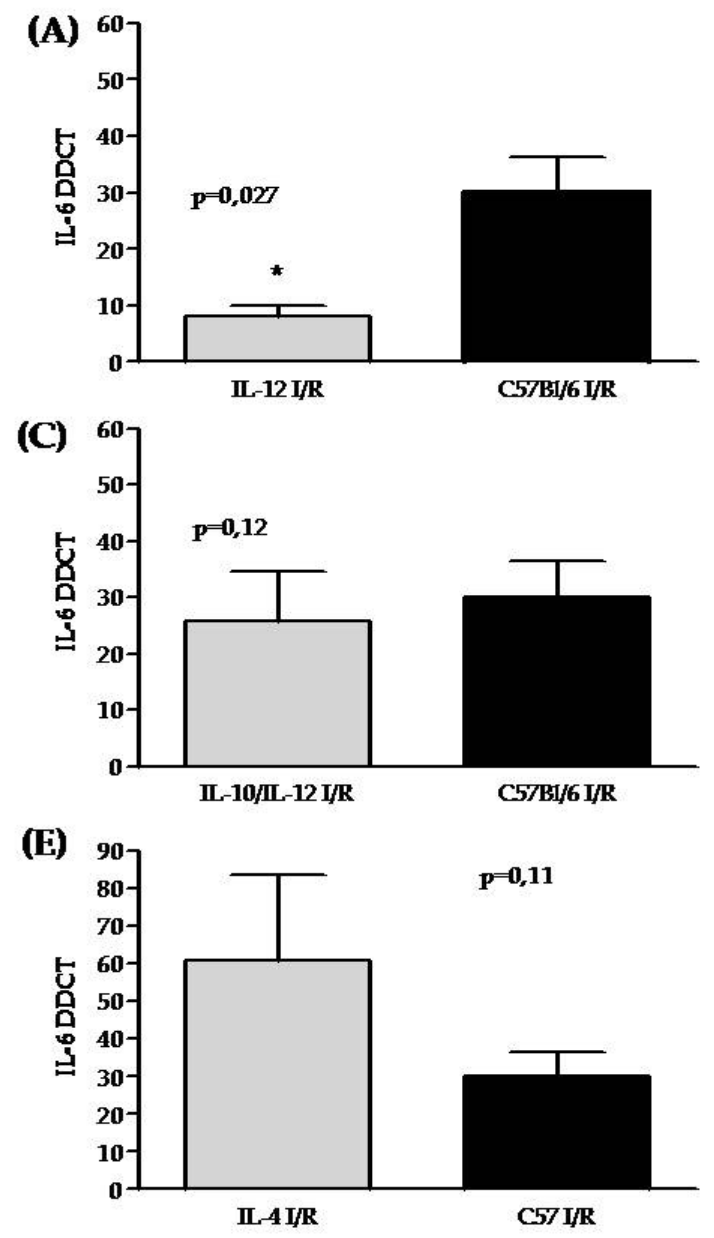
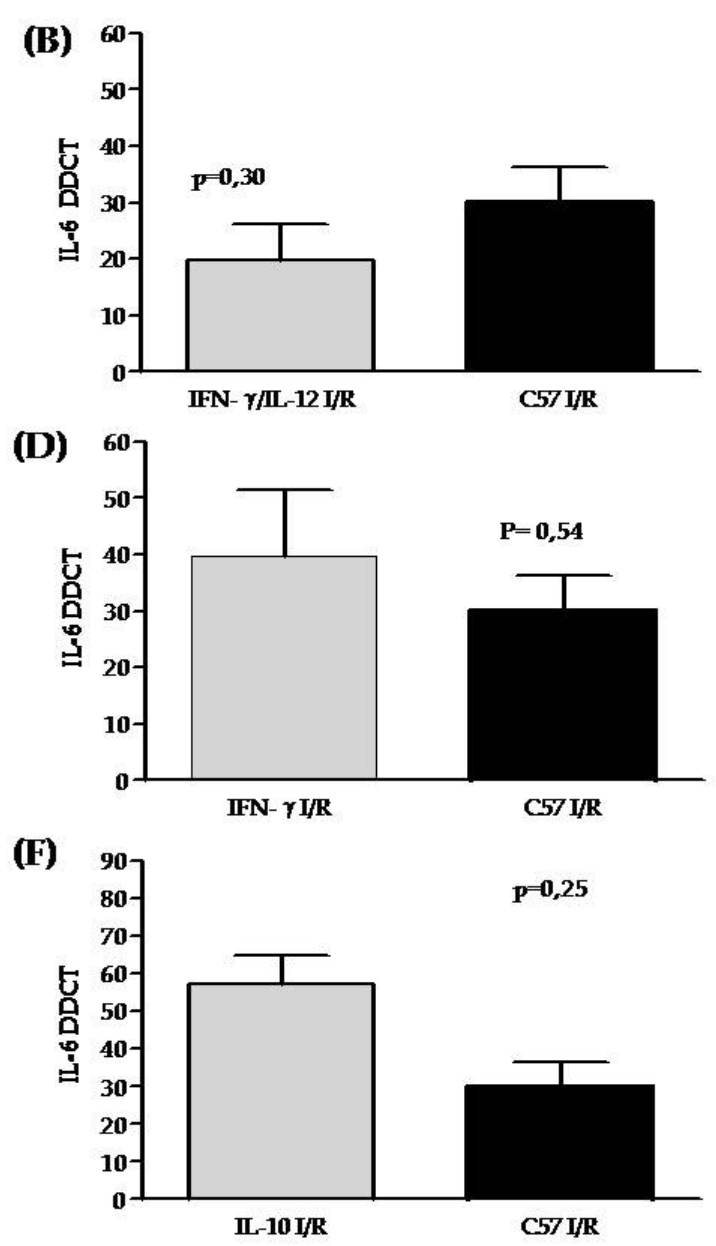

Figura 4.16.: Expressão do gene IL-6 nos rins dos animais selvagens e nos nocautes de $I L$ $12(A), I F N-\gamma / I L-12(B), I L-10 / I L-12(C), I F N-\gamma(D), I L-4$ (E) e $I L-10$ (F) após 24 horas de reperfusão. (*) Houve significância estatística entre os valores obtidos nos animais selvagens e nos nocautes para IL-12 . T-test. $N=4$-6.

Animais nocautes para IL-4 e para IFN- $\gamma$, que foram submetidos à lesão de I/R, apresentaram uma elevação da expressão do RNA mensageiro de IL-6 em relação aos animais selvagens, porém sem alcançar significância estatística. 


\subsubsection{Transcrito Gênico: HO-1}

Em paralelo à amplificação de citocinas pró-inflamatórias, quantificamos a HO-1, um gene considerado citoprotetor e que também se relaciona à resposta do tecido ao estresse [102].

Os animais selvagens submetidos à lesão de I/R apresentaram uma maior expressão da molécula em relação aos seus controles, shams e normais (Figura 4.10). Quando comparamos estes valores com os obtidos nos animais nocautes, também submetidos à cirurgia com ligadura reversível dos pedículos renais, observamos que os animais nocautes apresentaram expressões similares. Animais nocautes para IFN-g apresentaram uma maior expressão de HO-1 em relação aos controles selvagens, porém sem significância estatística (Figura 4.17). 

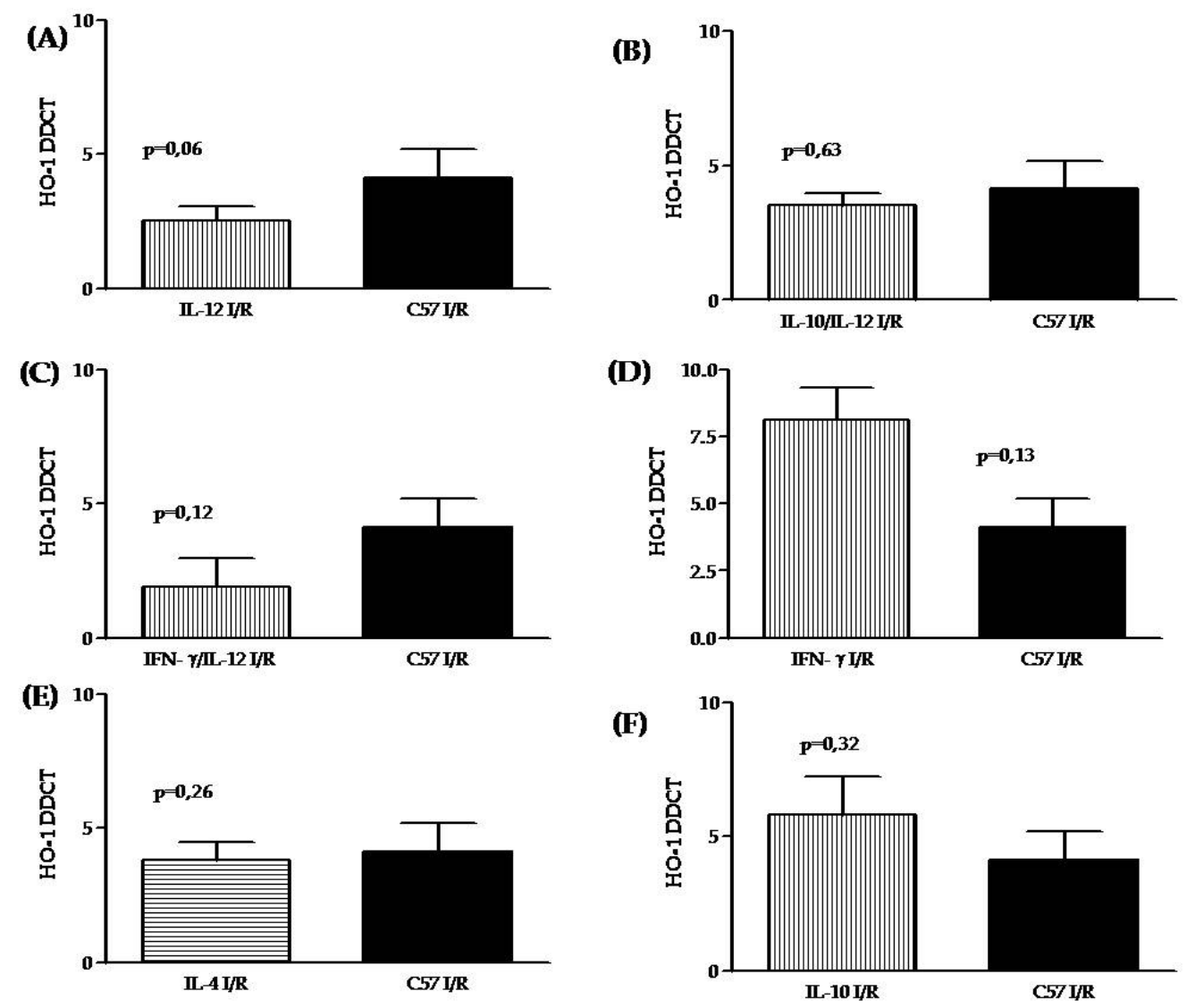

Figura 4.17.: Expressão do gene HO-1 nos rins dos animais selvagens e nos nocautes de $I L$ -

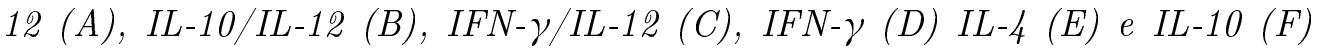
após 24 horas de reperfusão. Não houve significância estatística entre os valores obtidos nos animais selvagens e nocautes estudados. T-test. $N=4-6$.

\subsection{Correlação entre os valores do RNAm de IL-6 e HO-1 em todos os animais de todos os grupos estudados}

Considerando que a HO-1 é uma proteína de resposta ao estresse com atividade citoprotetoras, verificamos se existiria uma correlação positiva entre os seus valores e os de IL-6, que denotaria um grau de inflamação. Conforme visto na figura 4.18, os valores 
logaritmizados da HO- 1 se correlacionaram positivamente $(\mathrm{R} 2=0,47, \mathrm{p}<0,0001)$ com os valores da IL-6.

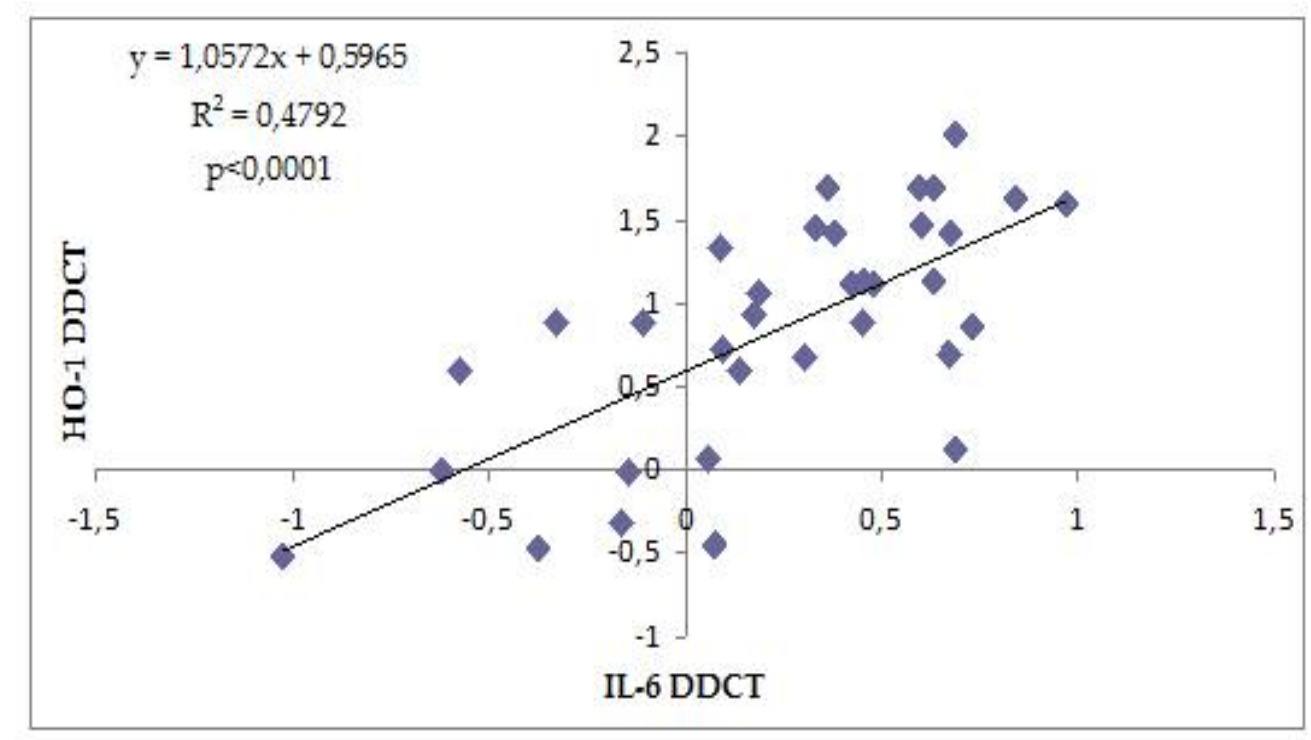

Figura 4.18.: Correlação entre os valores logaritimizados da expressão do RNAm dos genes IL-6 e da HO-1 em todos os animais de todos os grupos estudados. Houve significância estatístisca, com $p<0,0001$.

\subsection{Resultados Bioplex}

Atualmente, a lesão de I/R renal é considerada uma síndrome inflamatória com repercussões à distância [110]. Várias moléculas podem circular sistemicamente e ocasionar danos em órgãos como o pulmão, entre elas, as citocinas. Desta forma, quantificamos no soro algumas citocinas 24 horas após a reperfusão nos animais selvagens e nocautes submetidos à cirurgia de ligadura reversível dos pedículos renais.

\subsubsection{IL-6}

A IL-6 foi mensurada no tecido renal por PCR em tempo real e houve uma boa correlação com o grau de disfunção. Desta forma, a quantificamos no soro dos animais, como descrito anteriormente. 
Os animais que foram protegidos na lesão de I/R renal, os nocautes para IL-12 e os duplo-nocautes para IL-12/IFN- $\gamma$, não tiveram a presença da IL-6 quantificáveis no soro, mas os animais que não foram protegidos da lesão de $\mathrm{I} / \mathrm{R}$ renal, como os nocautes para IFN- $\gamma(3773 \pm 1759 \mathrm{pg} / \mathrm{mL})$ e os duplo-nocautes para IL-10/IL-12 (4163 \pm 1527 $\mathrm{pg} / \mathrm{mL}$ ), apresentaram uma maior concentração desta citocina quando comparados com os animais-controle selvagens $(400,2 \pm 170,2 \mathrm{pg} / \mathrm{mL}), \mathrm{p}>0,05$. Já os animais nocautes para IL-4 $(248,4 \pm 73,90 \mathrm{pg} / \mathrm{mL})$ e IL-10 $(283,9 \pm 66,59 \mathrm{pg} / \mathrm{mL})$ tiveram a presença no soro da IL-6 semelhantes aos animais-controle selvagens, todos submetidos à lesão de $\mathrm{I} / \mathrm{R}$ renal em 24 horas $(400,2 \pm 1,027 \mathrm{pg} / \mathrm{mL}), \mathrm{p}>0,05$ (Tabela 4.1).

\begin{tabular}{c|c|c|c}
\hline Grupo animais isquemiados 24 horas & Citocina KC & Citocina IL-6 & Citocina IL-4 \\
\hline \hline IL-12 KO & ND & ND & ++ \\
IFN- $\gamma /$ IL-12 KO & ND & ND & ++ \\
IFN- $\gamma$ KO & ++ & ++ & ++ \\
IL-4 KO & ++ & ++ & ND \\
IL-10 KO & ++ & ++ & ND \\
IL-10/IL-12 KO & ++ & ++ & ND \\
C57BL6 & ++ & ++ & ++ \\
\hline
\end{tabular}

Tabela 4.1.: Concentração (Pg/mL de citocinas e quimiocinas pró-inflamatórias (KC e IL6) no soro de camundongos nocautes ou controle-selvagem. $N=3 . N D=N a \tilde{o}$ Determinado; $++=$ Presença.

\subsubsection{IL-4}

Anteriormente, nosso grupo observou que os animais nocautes para IL-4 apresentavam um dano tecidual exacerbado, superior aos animais selvagens em relação à duração da gravidade [82]. Assim, quantificamos esta citocina no soro dos animais após a lesão de I/R.

A IL-4 esteve presente nos animais nocautes para IL-12 $(46,52 \pm 7,37 \mathrm{pg} / \mathrm{mL})$ e os duplo-nocautes para IL-12/IFN- $\gamma(37,08 \pm 1,5 \mathrm{pg} / \mathrm{mL})$ em níveis semelhante aos encontrados nos animais-controle selvagens $(31,67 \pm 1,027 \mathrm{pg} / \mathrm{mL}), \mathrm{p}>0,05$, todos submetidos 
à lesão de I/R.

Já os animais que representam defeito para polarização para o perfil Th2, os animais para IL-10 e IL-4 e o duplo-nocaute para IL-10/IL-12, não apresentaram níveis quantificáveis da IL-4 no soro (Tabela 4.1). Os animais shams e normais também não apresentaram níveis quantificáveis desta citocina.

\subsubsection{KC}

A lesão de I/R está relacionada, nas suas fases precoces, a um massivo influxo de neutrófilos. Estes neutrófilos quimioatraídos para o parênquima renal vão liberar enzimas, ERO, entre outras moléculas, que culminarão com mais influxo e lesão celular [111, 112]. Cientes disso, quantificamos uma quimiocina relacionada à quimotaxia de neutrófilos, a KC [113].

A citocina $\mathrm{KC}$ apresentou-se em maior concentração no soro dos animais nocautes para IL-4 (133,5 $\pm 46,75 \mathrm{pg} / \mathrm{mL}), \operatorname{IFN} \gamma(163,3 \pm \pm 11,99 \mathrm{pg} / \mathrm{mL})$ e IL-10 $(172,3 \pm \pm$ $28,42 \mathrm{pg} / \mathrm{mL}$ ) submetidos à lesão de I/R, semelhante ao observado nos animais-controle selvagens também submetidos à lesão de $\mathrm{I} / \mathrm{R}(126,1 \pm \pm 11,50 \mathrm{pg} / \mathrm{mL}), \mathrm{p}>0,05$. Os

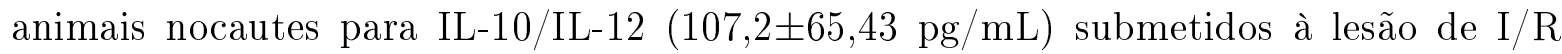
também apresentaram níveis séricos de KC semelhantes aos animais-controle selvagem $(\mathrm{p}>0,05)$.

Já os animais nocautes para IL-12 e os duplo-nocautes para IFN- $\gamma /$ IL-12 submetidos à lesão de I/R apresentaram uma baixa concentração de KC no soro $(25 \pm 12,7$ $\mathrm{pg} / \mathrm{mL})$ e $(13 \pm 8,4 \mathrm{pg} / \mathrm{mL})$, respectivamente (Tabela 4.1). 
Parte II.

Resultados dos grupos dos animais

\author{
quimeras
}


Seguindo a nossa hipótese inicial de que uma resposta Th1 seria deletéria para o tecido renal isquêmico, nossa próxima etapa foi investigar se a proteção observada nos animais nocautes para a IL-12 poderia ser re-estabelecida com a transferência adotiva de células totais da medula óssea de animais selvagens. Como controles, animais selvagens e nocautes para IL-4 foram usados.

\subsection{Caracterização dos esplenócitos de camundongos irradiados antes de receber a transferência adotiva de células totais da medula óssea}

Para verificar se os animais irradiados apresentavam depleção de suas células após 24 horas da irradiação, células do baço foram processadas conforme descrito nos materiais e métodos e analisadas por citometria de fluxo (Figura 4.19). Em todos os grupos, a população de linfócitos CD3+, CD4 + e CD $8+$ mostrou-se ausente, ou seja, negativa após 24 horas da irradiação por fonte de cobalto sugerindo que realmente houve depleção dos linfócitos. 


\section{Animais Irradiados}

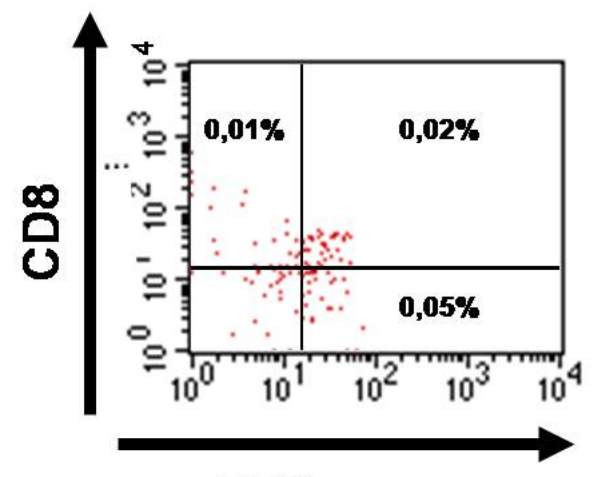

CD3

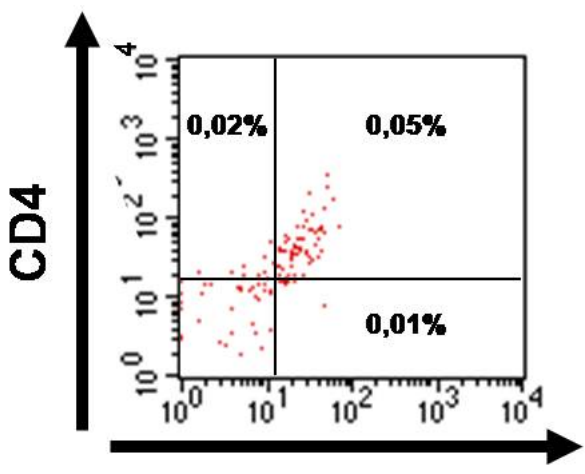

CD3

Figura 4.19.: Análise fenotípica dos linfócitos (CD3+, CD4+e CD8+) de baço de animais irradiados por fonte de cobalto após 24 horas da irradiação. As células foram marcadas com anticorpos monoclonais fluorescentes e analisadas através de Citometria de Fluxo (FACS), confirmando a depleção celular da medula desses animais.

\subsection{Caracterização dos esplenócitos nos}

\section{camundongos irradiados após 6 semanas do recebimento da transferência adotiva de células} totais da medula óssea

Para verificar se os animais irradiados que sofreram a transferência adotiva de células totais da medula óssea de um animal doador foram reconstituídos após 6 semanas da transferência adotiva, as células do baço foram processadas conforme descrito nos materiais e métodos e analisadas por citometria de fluxo (Figura 4.20). A população celular de linfócitos CD3+, CD4+ e CD8 + mostrou-se presente e em grande quantidade, sugerindo que os animais foram reconstituídos de forma adequada. 


\section{Animais Recontituídos com Medula Óssea após 6 semanas}

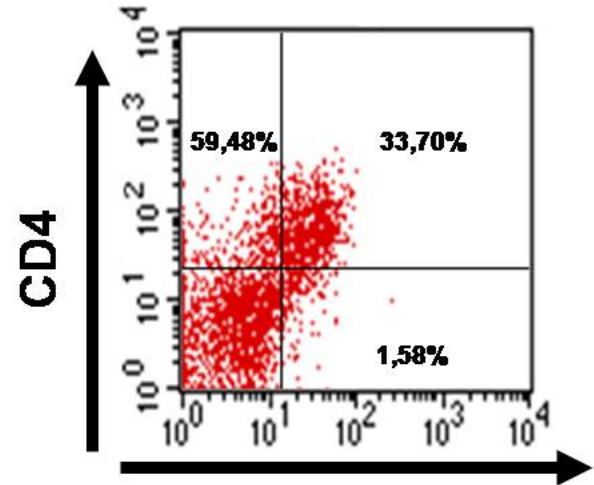

CD3

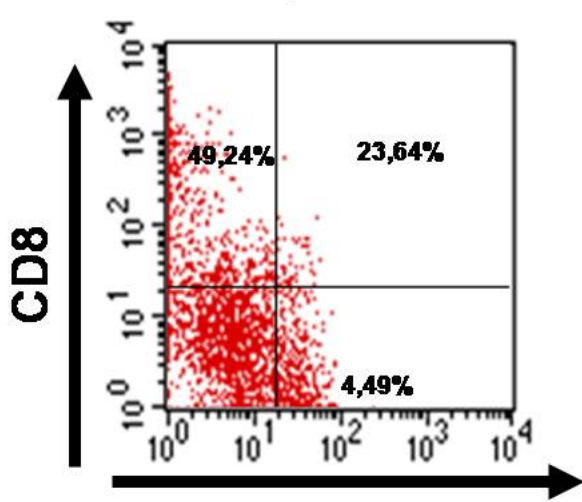

CD3

Figura 4.20.: Análise fenotípica dos linfócitos (CD3+, CD4+e CD8+) de baço de animais irradiados por fonte de cobalto após 24 horas da irradiação e que sofreram transferência adotiva de células totais de médula óssea (20 x 106 células totais de M.O) e que permaneceram durante 6 semanas reconstituindo a medula. As células foram marcadas com anticorpos monoclonais fluorescentes e analisadas através de Citometria de Fluxo (FACS), confirmando a reconstituição celular da medula desses animais.

\subsection{Peso}

Para a análise dos pesos, nós calculamos um delta de perda de peso, entre o valor inicial e o obtido no dia do sacrifício.

\subsubsection{Peso dos grupos dos animais nocaute para citocina IL-12 quimérico}

De uma forma geral, os animais perderam mais peso quando submetidos ao procedimento cirúrgico com a ligadura dos pedículos renais. Os animais IL-12 quiméricos que receberam células totais da medula óssea dos animais selvagens e foram submetidos à lesão de I/R apresentaram perda de peso semelante aos animais selvagens que receberam 
células totais da medula óssea dos próprios animais selvagens (Figura 4.21).

Por outro lado, quando os animais selvagens quiméricos que receberam células totais da medula óssea dos animais nocaute para citocina IL-12 e foram submetidos à lesão de I/R em 24 horas apresentaram menor perda de peso significantemente menor quando comparado com os animais controle selvagens que receberam medula óssea dos próprios animais selvagens (Figura 4.21).

a)

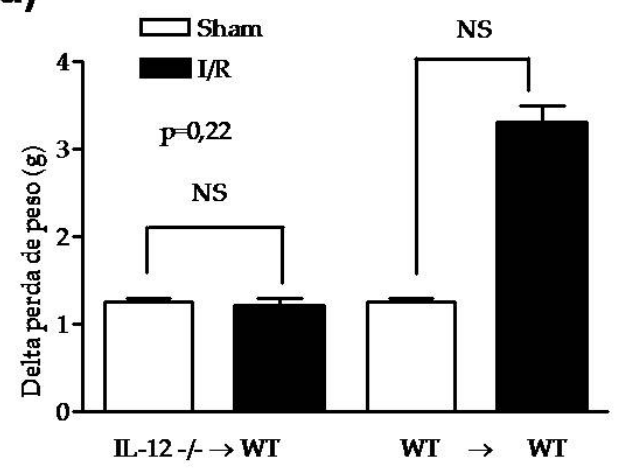

b)

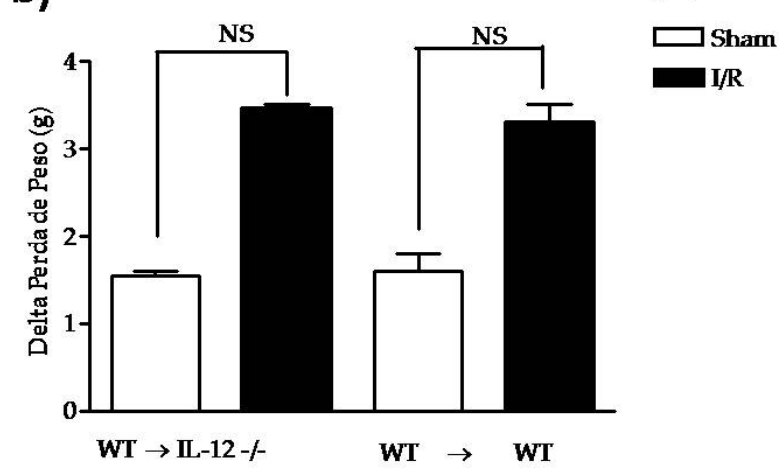

Figura 4.21.: Delta da perda de peso entre animais nocautes IL-12 reconstituído com células totais da medula óssea e sham e submetidos à lesão de $I / R$ renal em comparaçâo com os animais selvagens que também receberam transferência adotiva de células totais da medula óssea. Nẫo houve diferença estatística entre os grupos. ANOVA, N=4. WT-Controle selvagem-C57BL $/ 6$.

Todos os animais sham quiméricos apresentaram menores perda de peso quando comparado aos animais selvagens quiméricos submetidos à lesão de I/R renal em 24 horas.

\subsubsection{Peso dos grupos dos animais nocaute para citocina IL-4 quimérico}

Os animais nocaute para citocina IL-4 quiméricos que receberam transferência adotiva de células totais da medula óssea dos animais selvagens e foram submetidos à lesão de I/Renal em 24 horas apresentaram uma perda de peso semelhante àquela 
observada nos animais selvagens quiméricos que receberam medula óssea dos próprios animais selvagens que também foram submetidos à lesão de I/R renal (Figura 4.22).

No entanto, os animais selvagens quiméricos que receberam medula óssea dos animais nocaute para citocinas IL-4 e foram submetidos à lesão de I/R renal em 24 horas apresentaram também uma perda de peso semelhante àquela observada nos animais selvagens submetidos à lesão de $\mathrm{I} / \mathrm{R}$ em 24 horas, esses resultados possivelmente denotou uma maior gravidade da lesão renal nos animais quiméricos que não foram protegidos da lesão de I/R renal (Figura 4.22).

a)

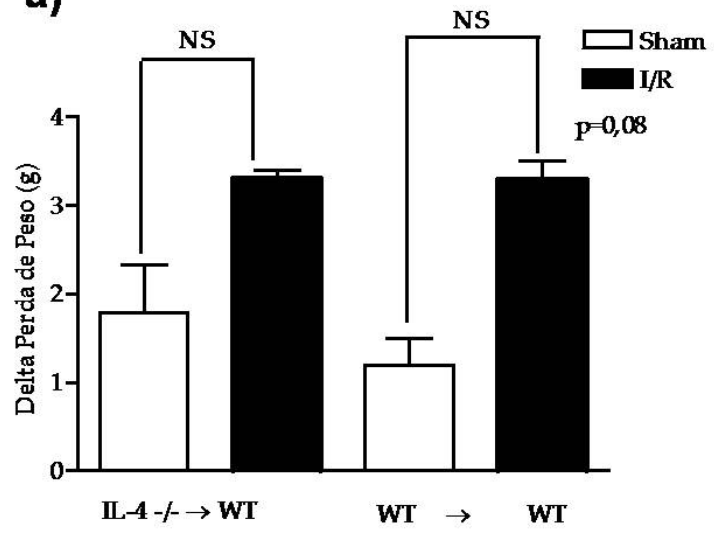

b)

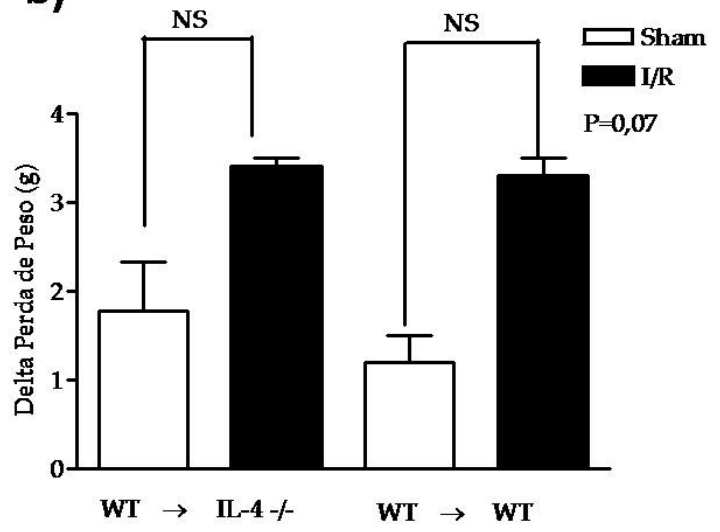

Figura 4.22.: Delta da perda de peso entre animais nocautes IL-4 reconstituído com células totais da medula óssea e sham e submetidos à lesão de IR renal em comparação com os animais selvagens que também receberam transferência adotiva de células totais da medua óssea. Não houve diferença estatítica entre os grupos. ANOVA, $N=3$. WT- controle selvagem $-C 57 B L / 6$.

Todos os animais sham quiméricos apresentaram menores perda de peso quando comparado aos animais selvagens quiméricos.

\subsection{Função Renal}

Nós utilizamos a dosagem sérica de uréia como método de avaliação da função renal. Amostras de soro colhidas com 24 horas de reperfusão foram usadas para o 
ensaio. E em todos os grupos dos animais estudados foram injetados vinte milhões de células intra-peritonealmente e, após seis semanas, esses animais foram submetidos à lesão de I/R renal em 24 horas.

\subsection{Função renal dos grupos dos animais nocaute para citocina IL-12}

O primeiro grupo a ser estudado foi dos animais nocautes para a citocina IL-12 que receberam a transferência adotiva de células totais da medula óssea dos animais controles selvagens. Animais quimeras foram também submetidos ao procedimento cirúrgico sem a ligadura dos pedículos renais.

Os animais nocaute para citocina IL-12 quiméricos apresentaram elevação nos valores de uréia sérica $(160 \pm 62,4 \mathrm{mg} / \mathrm{dL})$ superior à observada nos animais controles selvagens $(85 \pm 14,9 \mathrm{mg} / \mathrm{dL})$ que foram também reconstituídos com células da medula óssea dos próprios animais selvagens. Já os animais nocautes para IL-12 quiméricos do grupo sham apresentaram valores de uréia sérica $(49 \pm 7,0 \mathrm{mg} / \mathrm{dl})$ semelhante aos animais selvagens quiméricos apenas submetidos ao procedimento cirúrgico $(58 \pm 1,0 \mathrm{mg} / \mathrm{dL}$, Figura $4.23)$. 
a)

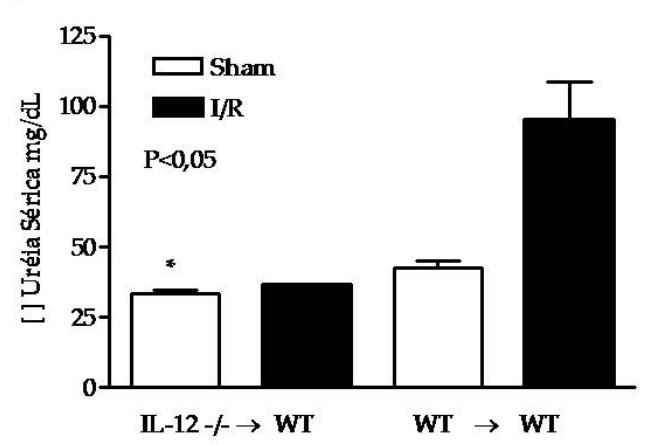

b)

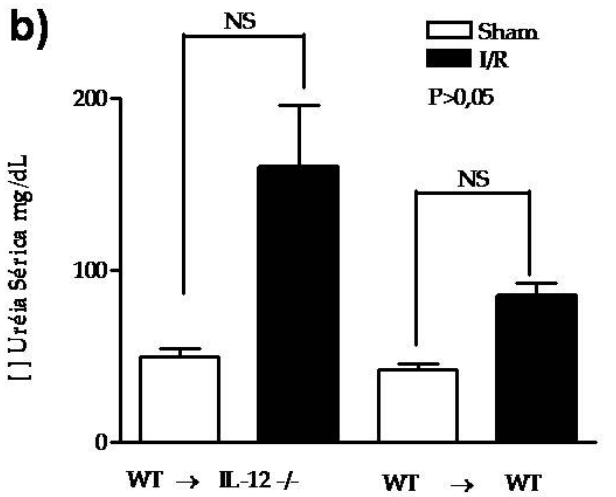

Figura 4.23.: Função renal após 24 horas de reperfusão nos animais selvagens reconstituídos com células totais da medula óssea de animais nocautes $I L-12$ (a), IL-12 -/- $\rightarrow$ $W T(b), W T \rightarrow I L-12-/-.\left(^{*}\right)$ Houve diferença estatistica entre os valores obtidos nos animais IL-12 -/- $\rightarrow$ WT. ANOVA, N=4. WT- controle selvagem$C 57 B L / 6$.

O segundo grupo a ser estudado foram dos animais controle selvagens que sofreram a transferência adotiva de células totais da medula óssea dos animais nocaute para citocina IL-12.

Os animais selvagens quiméricos apresentaram menores níveis de uréia sérica (36 \pm 0,7 Pg/mL) quando comparado aos animais controle selvagens que foram reconstituídos com células da medula óssea dos próprios animais selvagens $(95 \pm 4,9 \mathrm{Pg} / \mathrm{mL})$.

Já os animais selvagens quiméricos do grupo sham apresentaram valores de uréia sérica $(42,4 \pm 4,1 \mathrm{mg} / \mathrm{dl})$ semelhante aos animais nocaute para citocina IL-12 quiméricos apenas submetidos ao procedimento cirúrgico (33 $\pm 1,7 \mathrm{mg} / \mathrm{dL}$, Figura 4.23).

\subsection{Função renal dos grupos dos animais nocaute para citocina IL-4}

Da mesma forma estudada nos grupos anteriores, o primeiro grupo a ser estudado foram os grupos dos animais nocautes para citocina IL-4 que receberam células totais 
da medula óssea dos animais controle selvagens.

Os animais nocaute para citocina IL-4 quiméricos apresentaram elevação dos valores de uréia sérica $(152 \pm 13 \mathrm{mg} / \mathrm{dL})$ superior à observada nos animais controles selvagens quiméricos $(85 \pm 12 \mathrm{mg} / \mathrm{dl})$. Da mesma forma que descrito anteriormente, não houve diferenças entre os grupos shams dos animais nocautes para IL-4 ( $37 \pm 8,5 \mathrm{mg} / \mathrm{dL})$ e animais selvagens $(58 \pm 1,0 \mathrm{mg} / \mathrm{dL})$ quiméricos (Figura 4.24).

a)

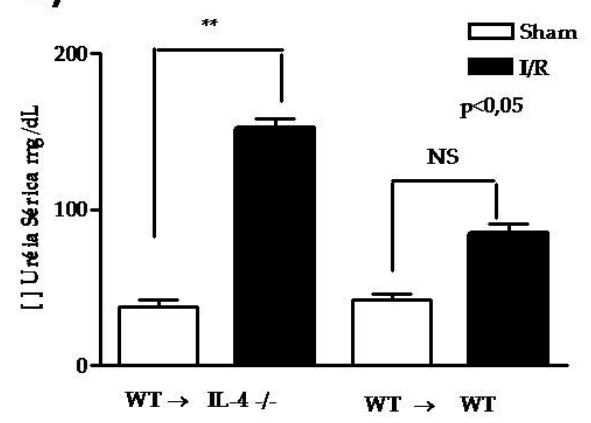

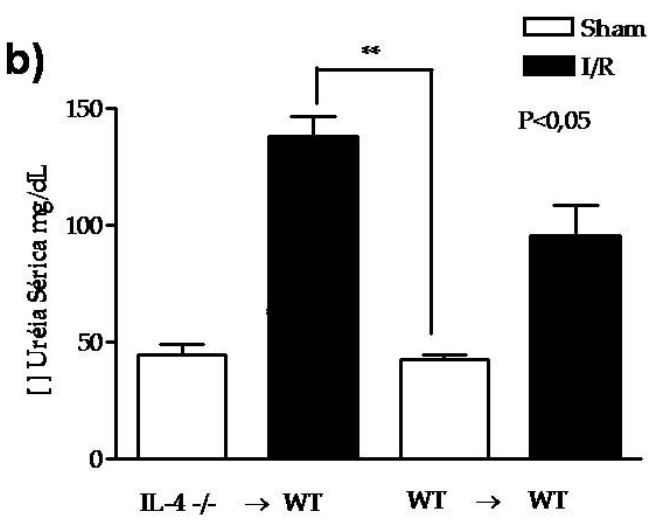

Figura 4.24.: Função renal após 24 horas de reperfusão nos animais selvagens reconstituídos com células totais da medula óssea de animais nocaute IL-4 (a), IL-4 -/- $\rightarrow$ $W T(b), W T \rightarrow I L-4-/-$. ( $\left.{ }^{* *}\right)$ Houve diferença estatistica entre os valores obtidos nos animais IL-4-/- $\rightarrow$ WT. ANOVA, N=4. WT- controle selvagem$C 57 B L / 6$.

Já o segundo grupo a ser estudado foram dos animais selvagens que receberam células totais da medula óssea de animais nocaute para citocina IL-4. Os animais selvagens quiméricos que foram submetidos à lesão de I/R (137 $15,2 \mathrm{mg} / \mathrm{dL})$ apresentaram valores de uréia superior à observada nos animais selvagens quiméricos reconstituídos com as próprias células da medula óssea também submetidos à I/R em 24 horas $(95 \pm 33 \mathrm{mg} / \mathrm{dL}$, p $>0,05)$. Não observamos também diferenças entre os grupos shams doa animais sel-

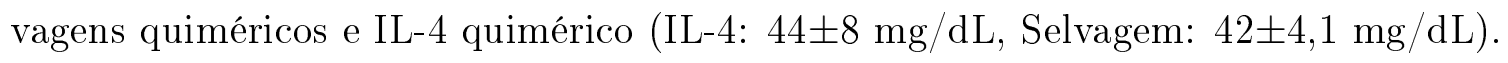




\subsection{Análise do RNA mensageiro de IL-6}

A reação em cadeia da polimerase em tempo real foi empregada para amplificação de um único gene estudado nesses grupos de animais quimeras, que foi a citocina próinflamatória IL-6.

Para todas as moléculas, as análises das reações empregaram os valores obtidos nos animais selvagens não manipulados como referência, ou seja, valor igual a um.

\subsubsection{Expressão de IL-6 nos grupos dos animais nocautes para citocina IL-12 quiméricos}

De forma interessante, os animais selvagens que receberam a transferência adotiva das células totais da medula óssea dos animais selvagens e que foram submetidos à lesão de I/R em 24 horas apresentaram maior expressão do RNAm da citocina IL-6. Enquanto, que os animais selvagens que foram irradiados e receberam a transferência adotiva de células totais da medula óssea dos animais nocautes para citocina IL-12 e que foram submetidos à lesão de I/R em 24 horas apresentaram baixa expressão de RNAm da citocina pró-inflamatória IL-6 (Figura 4.25). 
a)

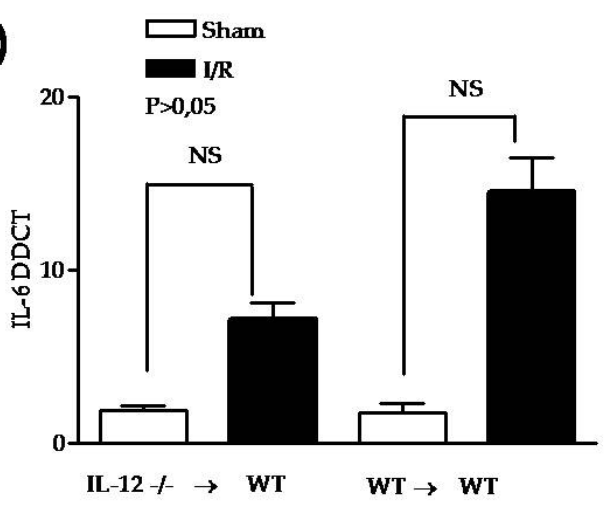

b)

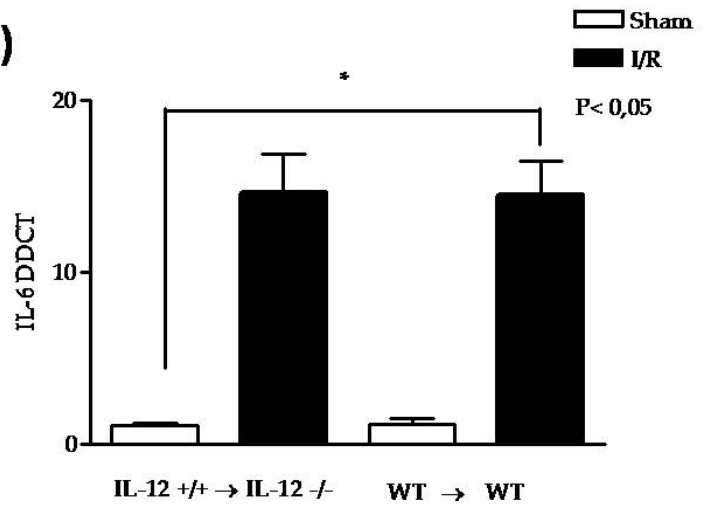

Figura 4.25.: Expressão do gene IL-6 nos rins dos animais selvagens quiméricos e nos animais $I L-12$ quiméricos (A), IL-12 -/- $\rightarrow$ WT (B), WT $\rightarrow I L-12-/-$ após 24 horas de reperfusão. Houve significância estatística entre os valores obtidos nos animais $W T \rightarrow I L-12-/-. A N O V A, N=4, W T-$ controle selvagem - C57BL/6.

Porém, quando fizemos o experimento contrário e transferimos células totais da medula óssea dos animais controles selvagens para os animais nocautes para citocina IL-12 e esses animais foram submetidos à lesão de I/R em 24 horas esses animais apresentaram alta expressão de RNAm da citocina pró-inflamatória IL-6 (Figura 4.25).

\subsubsection{Expressão de IL-6 nos grupos dos animais nocautes para citocina IL-4 quiméricos}

Posteriormente, os animais controles selvagens que foram irradiados e receberam a medula óssea dos animais nocautes para IL-4, e que em seguida foram submetidos à lesão de I/R, apresentaram uma alta expressão do RNAm da citocina IL-6 (Figura). De forma semelhante, os animais nocautes para IL-4 que foram irradiados e receberam a transferência adotiva de medula óssea dos animais selvagens apresentaram uma alta expressão de IL-6 (Figura 4.26). 
a)

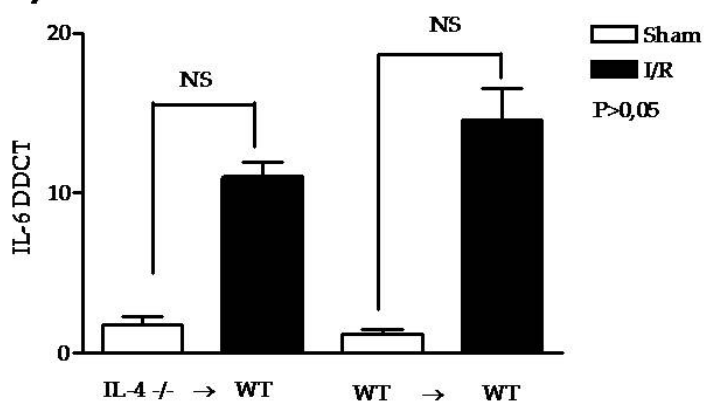

b)

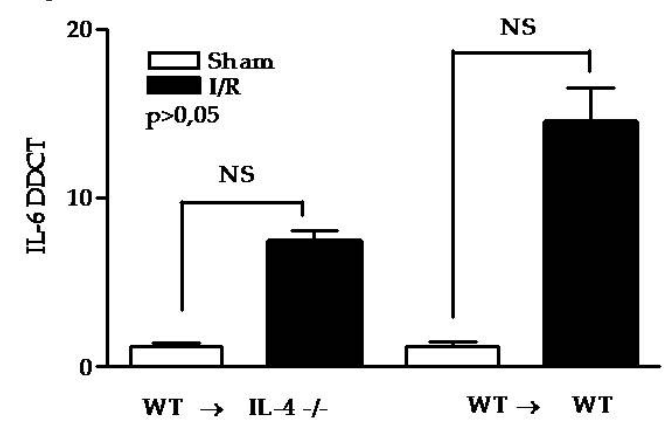

Figura 4.26.: Expressão do gene IL-6 nos rins dos animais selvagens quiméricos e nos animais IL-4quiméricos (A), IL-4 -/- $\rightarrow$ WT (B), WT $\rightarrow I L-4-/-$ após 24 horas de reperfusão. Nẫo houve significância estatística entre todos os grupos. ANOVA, $N=4$. WT - controle selvagem $-C 5 B L / 6$.

Em todos os casos, os animais shams apresentaram uma baixa expressão da citocina.

\subsection{Análise morfométrica: Necrose Tubular (NT) e Regeneração tubular (RT)}

Animais normais e os shams que receberam a transferência adotiva de medula óssea não apresentaram NT, nem no grupo selvagem e nem nos nocautes e, portanto, estes dados não foram discriminados aqui.

Os camundongos nocautes para citocina IL-4 que foram irradiados e receberam a transferência adotiva de células totais da medula óssea dos animais selvagens e foram submetidos à lesão de I/R em 24 horas apresentaram mais NT (39,6\%, 22,7-49,3), semelhante estatisticamente àquela quantificada nos camundongos selvagens que sofreram a transferência adotiva de células totais da medula óssea dos próprios animais selvagens $(29,8 \%, 19-24)$.

Os animais controles selvagens que foram irradiados e sofreram a transferência adotiva de células totais da medula óssea dos animais nocaute para IL-4 também apre- 
sentaram alta percentagem de necrose tubular aguda $(53,7 \%, 33-69)$ (Figura 4.27).
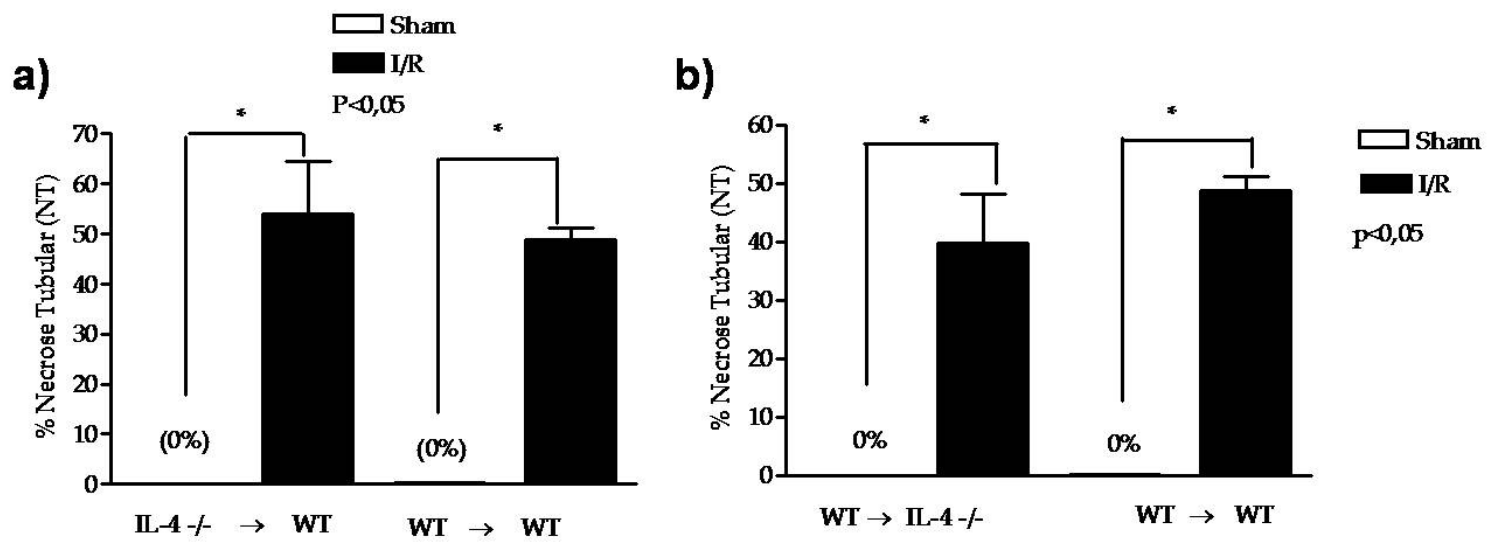

Figura 4.27.: Valores médios da percentagem de necrose tubular (NT) na medula externa dos animais selvagens quiméricos e nocautes IL-4 quiméricos submetidos a lesão de $I / R$ com 24 horas de reperfusão. (*) Houve significância estatística entre todos os grupos. ANOVA, N=4. WT-Controle Selvagem - C57BL $/ 6$.

Os animais nocaute para IL-12 que foram irradiados e receberam células totais da medula óssea dos animais controles selvagens e em seguida foram submetidos à lesão de I/R em 24 horas apresentaram um pequeno aumento na percentagem de NT $(8,7 \%$, 5,6-13) (Figura 4.28).

a)

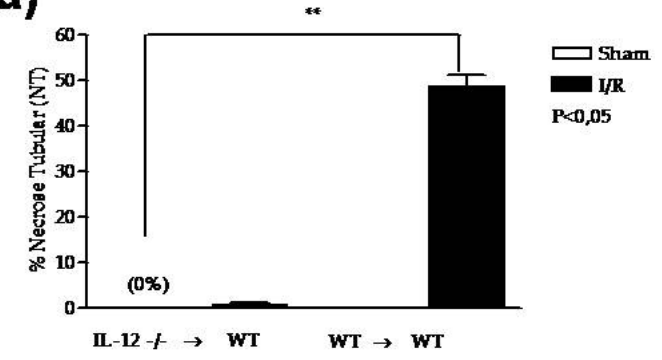

b)

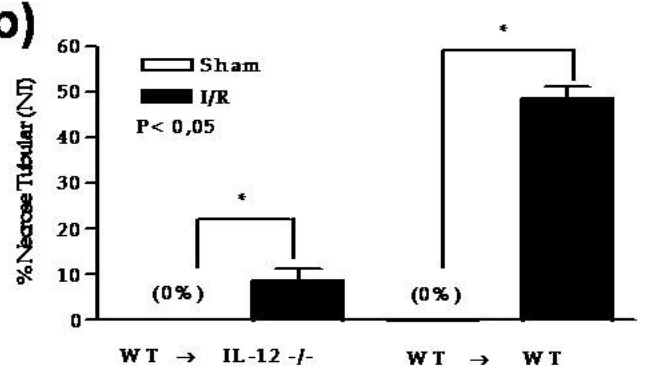

Figura 4.28.: Valores médios da percentagem de necrose tubular (NT) na medula externa dos animais selvagens quiméricos e nocautes IL-12 quiméricos submetidos a lesão de $I / R$ com 24 horas de reperfusão. (*) Houve significância estatística entre todos os grupos. ANOVA, N=4. WT-Controle Selvagem - C57BL $/ 6$.

Já os animais selvagens que receberam células totais da medula óssea de animais 
nocaute para citocina IL-12 e em seguida foram submetidos à lesão de I/R em 24 horas não apresentaram necrose tubular aguda (0\% $0-0)$.

Quando fomos analizar a regeneração tubular os animais nocaute para citocina IL-12 quiméricos que receberam células totais da medula óssea dos animais selvagens $(17,4 \%$ 3,8-17,46) apresentou regeneração tubular semelhante àquela apresentada pelos animais controles selvagens quiméricos que receberam células totais da medula óssea dos próprios animais selvagens $(19,8 \%$ 12,7-12,38) (Figura 4.29).
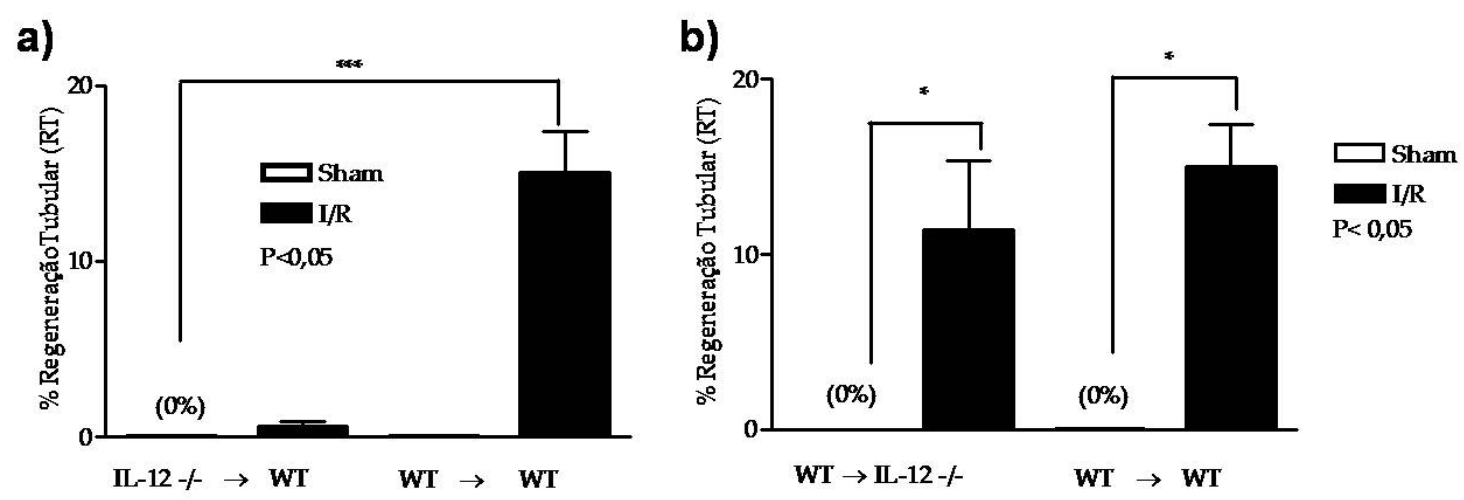

Figura 4.29.: Valores médios da percentagem de Regeneração tubular (RT) na medula externa dos animais selvagens quiméricos e nocaute $I L$-12 quiméricos submetidos a lesão de $I / R$ com 24 horas de reperfusão. (*) Houve significância estatística entre todos os grupos. ANOVA, $N=4-W T-C o n t r o l e ~ S e l v a g e m-C 57 B L / 6$.

Já os animais selvagens quimérico que receberam células totais da medula óssea dos animais selvagens quiméricos apresentaram menores regeneração tubular $(3,2 \%$ 2,44,3) quando comparado com os animais selvagens quiméricos todos submetidos à lesão de I/R em 24 horas.

Por outro lado, os animais nocaute para citocina IL-4 quiméricos que receberam células totais da medula óssea dos animais selvagens apresentaram maior regeneração tutubular (12,35\% 0-12), enquanto que os animais selvagens quiméricos que receberam células totais da medula óssea dos animais selvagens apresentaram maior regeneração tubular (13,8\% 8-13) quando comparado com os animais selvagens quiméricos (19,8\% 
12,7-12,38) (Figura 4.30).

a)

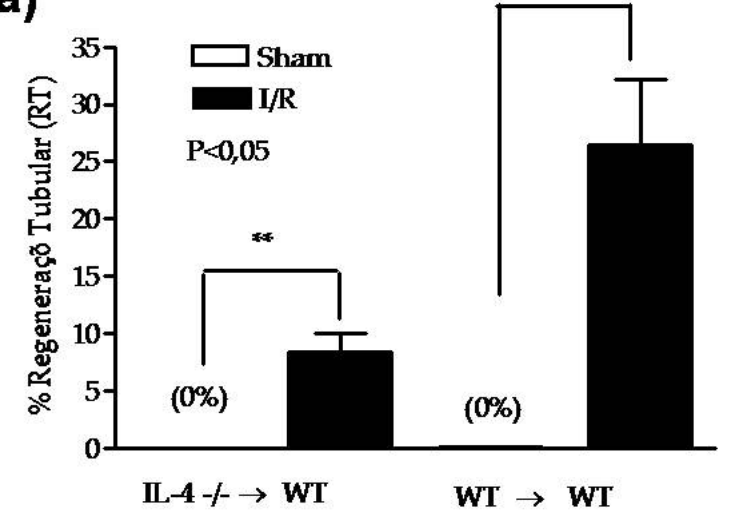

b)

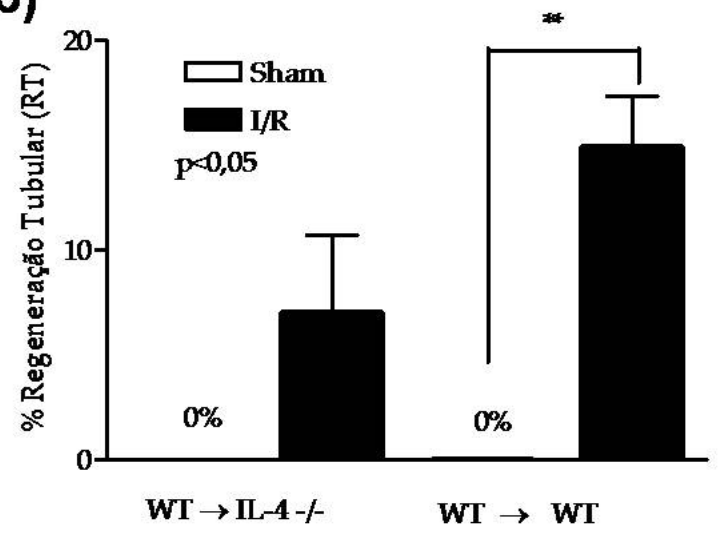

Figura 4.30.: Valores médios da percentagem de Regeneração tubular (RT) na medula externa dos animais selvagens quiméricos e nocautes IL-4 quiméricos submetidos a lesão de $I / R$ com 24 horas de reperfusão. (**) Houve significância estatistica entre todos os grupos. ANOVA, $N=4-W T-C o n t r o l e ~ S e l v a g e m-C 57 B L / 6$.

As alterações morfológicas características de RT na medula externa estiveram ausentes em todosos grupos dos animais sham e normais, tanto nos animais selvagens como nos nocaute para citocinas IL-12 e IL-4 que foram irradiados e receberam a transferência adotiva de células totais da medula óssea.

Os cortes histológicos dos rins com hematoxilina-eosina que ilustram os variados graus de NT nos animais selvagens, nocautes e duplo nocautes e submetido à lesão de I/R são discriminados na Figura 4.31. 


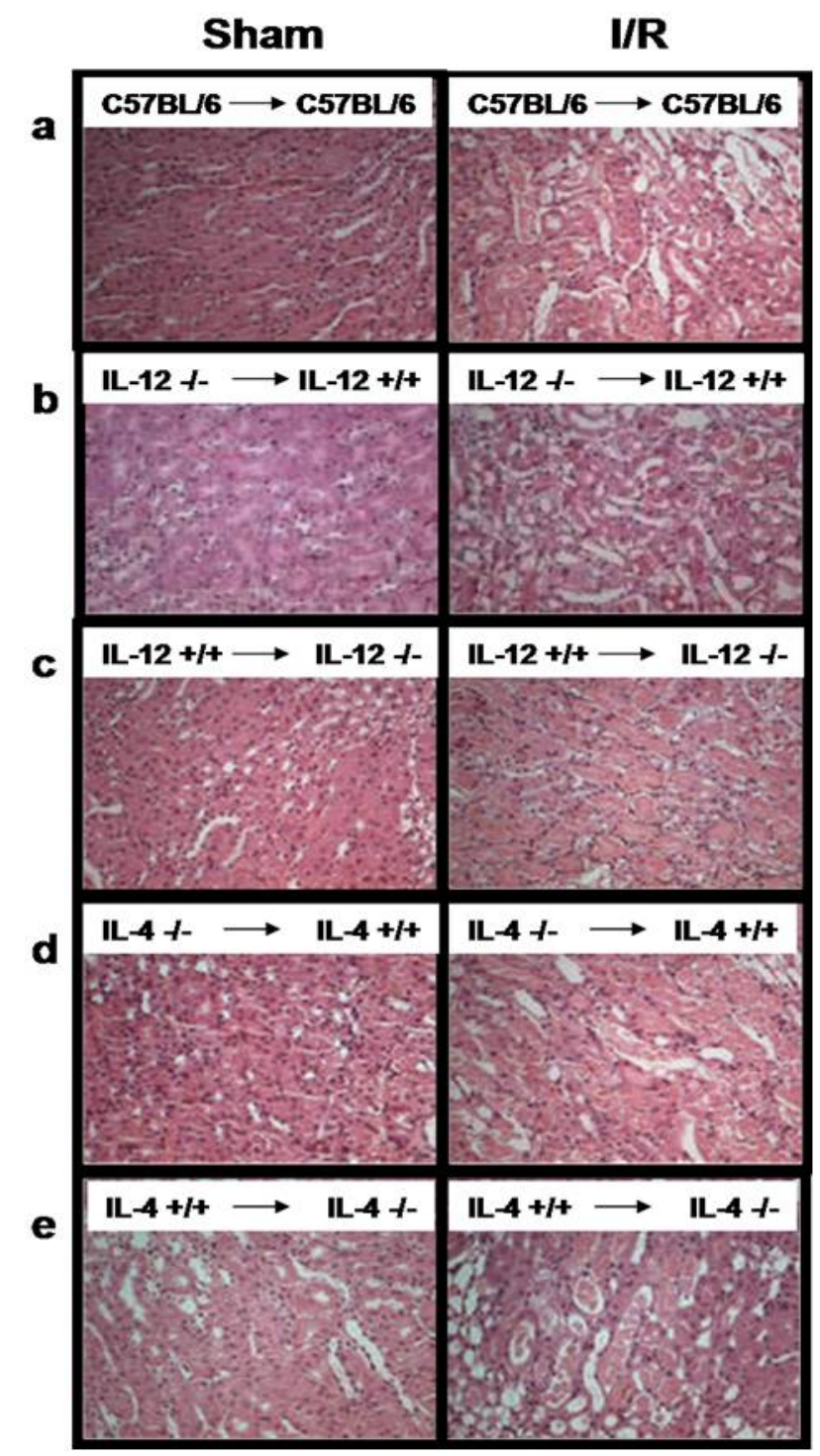

Figura 4.31.: Fotos ilustrativas de corte histológicos corado com HEEE mostrando alterações compativeis com Necrose Tubular (NT) e Regeneração Tubular (RT) dos grupos dos animais quiméricos e submetidos à lesão de $I / R$ com 24 horas de reperfusão: a) controle, b) IL-12 -/- $\rightarrow$ WT sham e $I / R, C) W T \rightarrow I L-12-/-$ Sham e $I / R$ ,d) $I L-4-/-\rightarrow W T$, e) $W T \rightarrow I L-4-/-$ Sham e I/R. ANOVA, N=3. Objetiva com aumento de $40 X$. 
5. Discussão 
A lesão renal aguda é atualmente considerada uma síndrome inflamatória, isto é, ela ocasiona uma resposta inflamatória que age diretamente no rim, induzindo lesão tecidual e, sistemicamente, afetando órgãos à distância [114, 115]. O conhecimento do papel da inflamação na patogênese da lesão renal aguda é relativamente recente e baseado quase que exclusivamente em dados experimentais em animais de laboratório. Dentre as causas de IRA, um estágio final de lesão renal aguda, a lesão de I/R, representa uma das mais importantes e freqüentes na prática clínica. Sua patogênese é complexa e envolve a presença de inflamação, além de distúrbios hormonais que levam a desregulação do tônus vascular e da filtração glomerular [112].

Recentemente, em nosso meio, Pinheiro e colaboradores [46] estudaram o papel do linfócito $\mathrm{T} \mathrm{CD} 4+$ na lesão de $\mathrm{I} / \mathrm{R}$ renal. Utilizando camundongos geneticamente modificados, deficientes na molécula de MHC de classe II, e animais depletados desta população com uso de anticorpo monoclonal, estes autores comprovaram dados prévios da literatura de que elementos da imunidade adquirida fazem parte da patogênese da lesão renal isquêmica. Em suma, estes dados demonstraram de forma quase inequívoca que linfócitos estavam relacionados à lesão tecidual desencadeada pela isquemia e agravada pela reperfusão. Vários trabalhos posteriores têm tentado elucidar o mecanismo efetor por trás desta observação [46, 116, 117, 103, 118, 119].

Yokota e colaboradores demonstraram que animais STAT-4 nocautes eram protegidos da lesão de I/R renal e hepática [120]. Posteriormente, nosso próprio grupo demonstrou que animais deficientes da citocina IL-12 eram completamente protegidos da lesão de I/R renal [82]. Estes dois trabalhos ilustram o conceito em que nos baseamos para desenvolver este projeto de mestrado: de que as citocinas de padrão Th1 são parte do mecanismo efetor da lesão de I/R renal.

Baseados nestes dados, tivemos como hipótese de trabalho o fato de que a secreção de citocinas de perfil Th1 seria deletéria para o rim isquemiado e que as citocinas de perfil 
Th2, protetoras. Para responder aos nossos objetivos, usamos um modelo já estabelecido de IRA experimental em animais geneticamente modificados. Para avaliar o grau de disfunção renal, optamos por estudar funcionalmente e histologicamente os danos renais e correlacioná-los com a expressão de algumas citocinas com ações pró-inflamatórias e uma molécula citoprotetora.

Antes de discutirmos os resultados, vale a pena discorrer brevemente sobre o modelo estudado e a abordagem experimental utilizada. O modelo experimental que mimetiza uma lesão renal por I/R está amplamente estabelecido na literatura e em nosso laboratório. Apesar de sua fácil execução, ele induz a uma lesão extremamente severa com uma extensa necrose tecidual e elevados níveis de escorias renais. Quarenta e cinco minutos de ligadura dos pedículos renais ocasionam óbito em cerca de $50 \%$ dos animais [104], ocorrendo geralmente 48 horas após a agressão isquêmica. Isto difere dos achados em humanos, em que a lesão histológica é muitas vezes segmentada e as alterações funcionais são mais brandas. No caso específico do estudo da lesão em órgãos a serem transplantados, este modelo não reproduz a lesão por isquemia fria, inevitavelmente presente no transplante de doadores falecidos [114, 121, 122]. Entretanto, como objetivamos estudar o papel de citocinas, este modelo permite o uso de animais geneticamente modificados, disponíveis em nosso meio. Os camundongos isogênicos da cepa C57BL/6 são os mais freqüentemente utilizados como "cepa selvagem" na construção de animais nocautes [119]. Finalmente, vale considerar que os resultados apresentam uma limitação, visto que estes animais podem apresentar mecanismos compensatórios pela falta da molécula deletada, e isso pode mascarar nossos resultados e influenciar nossa discussão.

Ciente disso, investigamos a participação de algumas citocinas, isoladamente ou em conjunto, na lesão de I/R renal. Aqui, optamos por avaliar os animais apenas em 24 horas após a ligadura reversível dos pedículos renais, correspondendo ao pico de 
lesão tecidual e funcional, já demonstrado em outros trabalhos do próprio laboratório $[116,81,122,123,10,47,120,48]$.

Uma desvantagem da execução deste modelo experimental é que a lesão de I/R renal é alcançada através do procedimento cirúrgico de laparatomia, com duração média de 1 hora e 15 minutos, favorecendo perdas insensíveis devido à exposição prolongada das vísceras abdominais, determinando assim modificações metabólicas importantes. De fato, em todos os grupos realizados, os animais evoluíram com uma perda de peso significativa no dia do sacrifício. A quantidade de peso perdido não se correlacionou com a gravidade da lesão renal, nem com a deficiência específica de uma citocina. Esperávamos que os animais protegidos perdessem menos peso, correspondendo às perdas insensíveis da cirurgia e, em menor grau, às decorrentes do catabolismo inerente a uma cirurgia. Entretanto, não observamos isso com 24 horas de acompanhamento, o que poderia significar um tempo curto de observação.

A determinação dos níveis séricos de creatinina e de uréia é classicamente utilizada como marcadores funcionais de lesão renal, guardando ótima correlação com a redução da taxa de filtração glomerular [1, 124], diferenciando apenas a metodologia de dosagem [10, 125, 126]. No nosso modelo, os animais apresentaram elevação da creatinina sérica após a cirurgia, com uma ótima correlação com os achados de necrose tecidual, comprovando a eficiência do modelo. Apesar de termos mostrado somente os valores de creatinina sérica, dosamos a uréia e ela apresentou o mesmo comportamento que a creatinina em todos os grupos (dados não mostrados). Somente nos animais nocautes para a IL-10, apresentamos os dados na forma de uréia sanguínea, visto que as dosagens de creatinina apresentaram flutuações, independente do estudo, inclusive com o soro padrão.

Em nosso estudo, não houve elevação significante dos níveis séricos de creatinina nos camundongos normais e nos camundongos deficientes para citocinas, submetidos ao procedimento cirúrgico sem o clampeamento das artérias renais (animais sham), em com- 
paração com os seus respectivos controles normais no tempo de 24 horas, mostrando que o procedimento cirúrgico, com a simples manipulação dos pedículos renais sem isquemia, não determinou prejuízo à função renal. Estes resultados reproduzem os achados de estudos anteriores, enfatizando que a anestesia e a cirurgia, através das quais se promove o episódio de I/R renal, não acarretam níveis detectáveis de deterioração da função renal, levando-se em conta a dosagem de creatinina [104, 127, 128, 129][21]. Se tivéssemos estudado um marcador urinário de lesão renal, talvez teríamos detectado dano renal após o simples procedimento cirúrgico [130].

Vários trabalhos demonstraram que intervenções na resposta imune, após a lesão de I/R renal, acarretavam melhora funcional. Klausner et al mostraram que a depleção de mais de $90 \%$ dos neutrófilos com soro depletante de neutrófilos reduzia em $60 \%$ os níveis de creatinina sérica em ratos submetidos a 45 minutos de isquemia renal [131]. Chiao et al observaram redução de $75 \%$ do infiltrado neutrofílico e níveis séricos de creatinina 50\% menores em camundongos deficientes na molécula de adesão ICAM-1 submetidos a 40 minutos de isquemia renal, em relação aos animais normais [127]. Estes dados mostram que a resposta inflamatória leva a uma disfunção renal, que pode ser reversível.

Quando analisamos os valores obtidos com os animais nocautes para a IL-12, comprovamos dados publicados anteriormente, nos quais estes animais eram protegidos da lesão renal [82]. Tilney e colaboradores já haviam demonstrado que, após a lesão de I/R, o rim apresentava aumentada a expressão de várias moléculas que caracterizariam uma resposta celular polarizada Th1, como IFN- $\gamma$ e IL-1 [132, 133]. A proteção observada nas análises funcionais foi corroborada pelas análises histológicas, demonstrando menores quantidades de necrose tubular aguda. No outro extremo, observamos que os animais nocautes para IL-4 e IFN- $\gamma$ não foram protegidos da lesão de I/R, apresentando valores semelhantes ao controle selvagem. Marques e colaboradores já demonstraram 
que uma resposta imune Th2 deficiente era relacionada à pior lesão tecidual [82]. O mesmo foi visto por Yokota e colegas com animais deficientes de STAT-4 [81].

A proteção observada nos animais nocautes para IL-12 demonstra claramente que a resposta desviada para um perfil Th1 é deletério na lesão de I/R renal [82]. A IL-12 é crucial para polarizar uma resposta imune Th1, sendo secretada por células apresentadoras de antígenos profissionais em resposta a uma agressão [60]. Isto levanta outro questionamento: quais células estariam produzindo a IL-12 e frente a quais antígenos. Outro trabalho na literatura demonstrou que as células dendríticas residentes após lesão de I/R renal produzia citocinas como TNF-alpha, IL-6 e MCP-1, que resultam no controle de ativação dos linfócitos $\mathrm{T}$ [32], enfatizando que estas células seriam fundamentais na resposta inflamatória na agressão renal aguda. Corroborando isso, trabalho realizado in vitro demonstrou que o uso de agonista de receptores Toll-like 3 e 9 estimulava a secreção de IL-12 pelas células dendríticas [125].

Da mesma forma, vários estudos têm avaliado os efeitos funcionais da participação das células T CD4 + nos mecanismos da lesão renal induzida pela I/R. Evidências indiretas do efeito lesivo das células T CD4 + na IRA isquêmica advêm de estudos do bloqueio da via co-estimulatória B7-CD28, necessária para a ativação das células T CD4+. No modelo experimental de isquemia fria em rins de ratos, Takada et al demonstraram que o bloqueio da molécula B7 com a proteína recombinante de fusão CTLA4-Ig aboliu completamente o aumento da creatinina sérica visto no grupo controle [16]. Da mesma forma, Ames et al mostraram que o bloqueio da molécula CD28, específica da célula T, com o anticorpo monoclonal JJ319, administrado no momento da reperfusão renal, reduziu em $76 \%$ os valores de creatinina sérica em relação ao grupo controle no ponto de maior lesão, 2 dias após o insulto isquêmico [134].

O papel do IFN- $\gamma$ na lesão de I/R é mais controverso. Esta citocina está classicamente relacionada à imunologia celular contra patógenos intracelulares e, especificamente 
no rim, à resposta inflamatória isquêmica e tóxica. Zhai e colegas demonstraram que o IFN do tipo I, e não do tipo II, está criticamente envolvido na lesão de I/R hepática [135]. Em contraposição a esses dados, Day e colaboradores demonstraram um papel protetor importante para o IFN- $\gamma$ produzido pelos linfócitos T CD4+ na lesão de I/R renal [49]. Os nossos dados não evidenciaram um papel relevante desta citocina no nosso modelo. Vale ressaltar que no trabalho anterior de Tilney e colegas, o IFN- $\gamma$ só foi detectado de forma significativa após 3 dias de insulto [115]. Talvez a proteção possa ser observada mais tardiamente, já que apenas estudamos um pico precoce de reperfusão. Novos pontos de estudo precisariam ser feitos para comprovar a participação do IFN- $\gamma$ no nosso modelo. Por outro lado, outro trabalho publicado demonstrou que animais selvagens que receberam transferência adotiva de células totais da medula óssea de animais IFN- $\gamma$ nocaute foram protegidos da lesão de I/R renal em 24 horas [136].

De forma interessante, os animais duplo-nocautes IL-12/IFN- $\gamma$ apresentaram uma proteção renal à lesão de I/R superior a observada nos animais deficientes para IL-12 e nos animais deficientes de IFN- $\gamma$, demonstrando uma cooperação entre as duas vias, e que a IL-12 é mais importante em polarizar a uma resposta deletéria para o rim. Os dados disponíveis sobre a participação destas citocinas na lesão de I/R são limitados. Estudo com modelos de infecção bacteriana demonstrou que o IFN- $\gamma$ não era necessário para a depuração de Pseudomonas [137]. Num modelo de inflamação de glândulas lacrimais, a participação conjunta de IL-12 e IFN- $\gamma$ é necessária para a destruição da glândula e para promover o infiltrado inflamatório [138]. O mesmo grupo demonstrou efeito semelhante para induzir inflamação hepática [139]. Dados já publicados demonstraram que animais nocaute para subunidade p40 da citocina IL-12 eram mais susceptíveis a infecções causadas por bactérias intracelulares e esses animais apresentavam deficiência na produção de IFN- $\gamma$, demonstrando que a produção de IFN- $\gamma$ é dependente da citocina IL-12. Sendo assim, nossos dados apenas confirmam essa hipótese: onde esses animais 
foram protegidos da lesão de $\mathrm{I} / \mathrm{R}$ renal, apresentaram menor percentagem de necrose tubular e expressão de RNAm de IL-6.

A deficiência associada de IL-10 e IL-12 levou a uma perda na proteção renal à lesão isquêmica, denotando que a IL-10 poderia ser um elemento protetor no nosso modelo. Animais deficientes em IFN- $\gamma$ apresentam uma elevação plasmática de IL-10, que justifica sua inabilidade em eliminar bactérias de forma adequada [137]. De forma inversa, animais deficientes em IL-10 e infectados com P. carinii apresentam uma elevada concentração de IFN- $\gamma$ e IL-12, demonstrando uma íntima associação entre estas duas citocinas [140]. Nossos dados corroboram estes últimos, em que a deleção da citocina IL-10 abole o efeito protetor da deleção da IL-12. Detectamos um aumento sérico de IL-10 nos animais deficientes para IL-12, maior que o controle selvagem, porém sem significância estatística (dados não mostrados). Estudos com ratos tolerantes ao LPS, que foram submetidos à lesão de $\mathrm{I} / \mathrm{R}$ renal, apresentaram maior expressão de RNAm da citocina IL-10, demonstrando que a citocina IL-10 apresenta um importante papel modulador nesse modelo [141].

Em todos os grupos, os dados de morfometria renal foram diretamente associados aos dados bioquímicos. Em resumo, os nossos dados demonstram que as citocinas associadas a uma resposta imune polarizada Th1 seriam deletérias para o rim lesado. Para aprofundar esta hipótese, quantificamos duas citocinas pró-inflamatórias em amostras de rim após a reperfusão.

A interleucina-6 (IL-6) é uma citocina pleiotrópica que regula a resposta imune e a inflamação. Superprodução de IL-6 tem sido associada a doenças autoimunes, tais como a artrite reumatóide [142]. A IL-6 pertence a uma família de citocinas que divide uma subunidade do receptor (gp130) com outras citocinas, como a IL-11 e o fator inibitório da leucemia (LIF). Mais recentemente, muita atenção tem sido dada pela importância da IL-6 na geração de células Th17 [143]. Kaminska e colegas demonstraram a presença 
de IL-6 em rins de transplantados renais com lesão de I/R [144]. Animais nocautes para a HO-1, submetidos à lesão de I/R, apresentam uma alta expressão de IL-6 [145]. De forma interessante, Dong e colegas demonstraram que IL-6 e IL-1b eram produzidas pela suspensão celular oriunda de rins isquemiados [32], demonstrando uma possível participação de linfócitos na lesão de I/R como mecanismo efetor.

Os animais que não foram protegidos da lesão de I/R renal em 24 horas, como os animais nocaute para citocina IL-12 e os animais duplo-nocaute para citocinas IFN$\gamma /$ IL-12 apresentaram baixa expressão da citocina IL-6, enquanto que os animais que não foram protegidos da lesão de I/R renal, como os animais nocaute para citocina IL-4, IL-10 e os duplo-nocaute para IL-10/IL-12, apresentaram maior expressão da citocina IL-6. Em outras palavras, nossos dados mostram que a IL-6 é altamente expressa nos animais selvagens e naqueles que não apresentaram uma proteção à isquemia.

Os dados com IL-1b não ficaram tão evidentes como os observados com a IL-6 e, por esta razão, não foram mostrados aqui, nos induzindo a pensar que tempos mais tardios sejam o ideal para o seu estudo.

Outro gene estudado foi a MCP-1. Ela é uma quimiocina produzida por fagócitos mononucleares, células endoteliais, fibroblastos e células $T$, ativados na vigência de uma resposta inflamatória aguda capaz de induzir a migração e a ativação de leucócitos, de influenciar a hematopoiese e de modular a angiogênese no local do processo inflamatório [124]. O epitélio tubular renal é capaz de gerar MCP-1, favorecendo assim a lesão renal determinada pela infiltração leucocitária induzida pela I/R renal [11]. A migração de macrófagos para a medula externa de rim de rato foi observada em modelo experimental de I/R renal, com hiper-regulação MCP-1, com atração de macrófagos [1]. Previamente, Rice et al descreveram o papel proeminente das quimiocinas na resposta inflamatória aguda de doenças renais e mostraram um aumento na expressão de RNAm de MCP-1 em rins de ratos submetidos a 50 minutos de isquemia renal bilateral, correlacionada à 
intensa infiltração de monócitos/macrófagos nos rins isquêmicos e à excreção urinária aumentada de MCP-1 [124].

Em nosso estudo, verificamos que a expressão de RNAm de MCP-1 nos camundongos deficientes em IL-4, IL-10, IFN- $\gamma$ e duplo-deficientes em IL-10/IL-12 foi estatisticamente superior àquela nos camundongos deficientes em IL-12 e nos animais duplodeficientes em IFN- $\gamma /$ IL-12, porém, sem atingir significância estatística. Tais achados condizem com o maior grau de disfunção renal e de infiltração inflamatória celular observada na análise histomorfométrica dos camundongos deficientes em IL-4, IL-10, IFN- $\gamma$ e duplo-deficientes em IL-10/IL-12 quando comparada com os camundongos deficientes em IL-12 e duplo-deficientes em IFN- $\gamma /$ IL-12. Idealmente, deveríamos ter mostrado maior grau de infiltrado macrofágico nestes animais.

Em nosso estudo, fomos também investigar a infiltração de macrófagos no rim dos animais estudados, nocautes e controles. Através da técnica por imunohistoquímica, utilizamos marcador F4/80, mas, após várias tentativas, os resultados se mostraram inviáveis, apresentando background e marcação inespecífica, possivelmente pela forma de preservação do material.

Além disto, observamos que a expressão ascendente de RNAm de MCP-1 nos camundongos deficientes em IL-4 ocorreu de forma inversamente proporcional à expressão decrescente de RNAm de HO-1, podendo corroborar a hipótese aventada por alguns autores de que exista um mecanismo de "feedback" negativo entre a expressão de MCP-1 e HO-1, onde os níveis mais elevados e precoces de HO-1 são acompanhados pela inibição da expressão de MCP-1 [126]. Assim sendo, esses dados reforçam o argumento da possível influência protetora das células Th2 e favorecem a hipótese de que a influência deletéria das células Th1 na lesão renal induzida pela I/R poderia estar relacionada com a maior expressão de RNAm de genes pró-inflamatórios, como o da MCP-1.

O papel fundamental da indução do gene de HO-1 na recuperação da função renal 
tem sido descrito em modelos experimentais de IRA induzida pela I/R. A expressão de HO-1 aumenta nos rins submetidos ao insulto isquêmico e sua inibição resulta em uma piora da função e da lesão histológica renal, indicando que a expressão de HO-1 pode exercer um efeito crucial no processo de citoproteção do tecido renal submetido à $\mathrm{I} / \mathrm{R}$ [146].

A regulação da expressão gênica de HO-1 parece ser específica para cada célula, sendo estimulada em situações que produzem estresse tecidual e tendo a capacidade de modular respostas protetoras e adaptativas essenciais para a homeostase celular em condições desfavoráveis, como na lesão renal isquêmica [86]. Estudo de Chauveau et al (2005) mostrou que a expressão de HO-1 bloqueia a maturação de células dendríticas e inibe as respostas imunes alogênicas e a secreção de citocinas pró-inflamatórias, enquanto preserva a produção da citocina anti-inflamatória IL-10 [147]. Em outro estudo, Chen e colegas em 2005 e colegas observaram que a atenuação da inflamação e proliferação neointimal em aloenxertos aórticos de ratos pela IL-10 é intermediada pela HO-1, uma vez que a inibição da atividade da HO-1 refez tanto a proliferação como a inflamação neointimal [148]. Previamente, Ke et al (2004) demonstraram em modelo experimental de I/R em transplante hepático que o bloqueio da via co-estimulatória CD40-CD154 por transferência gênica de CD40Ig protegeu os fígados de ratos da lesão isquêmica, acompanhado por um aumento da expressão de RNAm de HO-1 e IL-4 [149].

Os camundongos deficientes em STAT-4, que foram protegidos da lesão isquemia hepática, apresentavam expressão aumentada da proteína HO-1, mostrando que a citoproteção hepática ocorria de maneira dependente deste gene citoprotetor.

Em nosso estudo, verificamos que a expressão de RNAm de HO-1 nos camundongos deficientes em IL-4, IFN- $\gamma$, IL-10/IL-12 e IL-10 foi estatisticamente superior àquela nos camundongos deficientes em IL-12 e IFN- $\gamma / \mathrm{IL}-12$ após a I/R renal. Tais achados coincidem com os graus mais pronunciados de insuficiência renal e de necrose tubular 
aguda induzida pela I/R. Como a HO-1 é uma proteína de estresse celular, estes danos também denotam seu papel de sensor de agressão [150]. Para demonstrar esta hipótese, realizamos uma correspondência entre os níveis de IL-6 e os de HO-1 e observamos que a expressão de IL-6 se correlaciona positivamente com a expressão de HO-1, ou seja, onde tivemos maior disfunção renal a HO-1 era mais expressa.

Estudamos também a expressão de RNAm de dois fatores de transcrição essenciais para diferenciação Th1 e Th2, T-bet e GATA-3, respectivamente. A expressão de Tbet correlaciona-se com a indução de IFN- $\gamma$ e é detectada em uma variedade de células como as células T CD4+, CD8 + e NK. Após a diferenciação in vitro das células T CD4+ "naive", o T-bet é seletivamente expresso nas células Th1 e não nas células Th2. Células $\mathrm{T}$ CD4 + de camundongos deficientes em T-bet apresentam um defeito importante nas respostas polarizadas Th1. Sendo o mesmo observado para o fator de transcrição GATA3 e resposta Th2.

Observamos que as expressões desses marcadores se apresentaram baixos em todos os grupos estudados, não correlacionando uma polarização Th1/Th2. O trabalho publicado pelo nosso grupo em 2006 demonstrou que os linfócitos estavam presentes no rim em tempos iniciais (6 horas) e retornavam para o rim em tempos mais tardios (72 horas). Por esta razão no tempo de 24 horas, não encontramos a presença dos linfócitos T no rim [82]. Resultados preliminares que realizamos, mas não demonstramos nesta tese, confirmaram os dados da literatura, em que animais nocautes para os linfócitos $\mathrm{T}$ CD4 + e CD8 + eram protegidos da lesão de $\mathrm{I} / \mathrm{R}$ renal e os animais nocaute para molécula principal de histocompatibilidade (MHC) de classe II, que são deficientes de linfócitos $\mathrm{T}$ CD4+, também se apresentaram protegidos da lesão de I/R renal (dados não publicados).

O modo como as células T CD4+ ativadas e suas formas fenotípicas de apresentação Th1/Th2 promovem seus efeitos na $\mathrm{I} / \mathrm{R}$ renal permanece ainda como um ponto a ser 
esclarecido. A forma clássica de ativação das células $\mathrm{T}$ envolve a apresentação de um peptídeo antigênico no contexto de uma molécula de MHC de classe II por uma célula apresentadora de antígeno às células T CD4 + ou em uma molécula de MHC de classe I às células T CD8+. Além disto, necessita da interação de moléculas co-estimulatórias das superfícies do linfócito T e das células apresentadoras de antígeno, seguido da produção de citocinas que ativam macrófagos e promovem a proliferação clonal de linfócitos $\mathrm{T}$ e B [151].

Como os linfócitos poderiam ser ativados em um processo inflamatório renal que é independente de patógenos? Alguns autores colocam a hipótese de que a lesão de I/R promoveria modificações tais na estrutura celular que fariam com que algumas moléculas perdessem sua capacidade de serem reconhecidas como próprias e passassem a ser reconhecidas como estranhas [152]. Outros autores sugerem que as EROs, produzidas pelos tecidos submetidos à $\mathrm{I} / \mathrm{R}$, possam mediar as prováveis alterações estruturais em moléculas próprias, gerando uma resposta imunológica específica [146]. Outra possibilidade aventada é a de que as células $\mathrm{T}$ possam ter sido ativadas diretamente por quimiocinas produzidas no tecido renal após a lesão pela I/R [124]. Rice et al relataram o aumento da expressão de RNAm de MCP-1 correlacionada ao aumento da infiltração de monócitos/macrófagos em modelo experimental de I/R renal [153]. Bacon et al mostraram que o RANTES era capaz de ativar as células T, desencadeando a síntese de IL-2 e IFN- $\gamma$ sem a presença de antígenos, sendo que esta ativação era mediada por proteína-quinases e que esta propriedade não era partilhada por outras quimiocinas [59].

Outra hipótese fisiopatológica para a ativação das células T na lesão renal induzida pela I/R é a do reconhecimento do sistema imune inato à lesão isquêmica. Nesta teoria, as respostas do sistema imune seriam desencadeadas pela agressão tecidual, reconhecendo e iniciando uma resposta estereotipada na presença do "perigo" [154]. Tais aspectos são especialmente importantes quando a $\mathrm{I} / \mathrm{R}$ ocorre em enxertos renais onde a resposta à 
lesão isquêmica poderia facilitar a resposta aos alo-antígenos e deflagrar rejeição aguda a estes enxertos [155].

Na verdade, ainda não se sabe ao certo como esses linfócitos são ativados na lesão de I/R, apenas se sabe que eles participam. Já foram identificadas diferentes populações de linfócitos no rim após a lesão de I/R, mas ainda são necessários mais estudos para saber como esses linfócitos migram e como são ativados no rim. Um trabalho publicado em 2007 pelo grupo do Professor Hamid Rabb descreve justamente vários fatores que podem estar envolvidos com a ativação dos linfócitos durante a lesão de I/R renal. Um deles seria que as células tubulares renais podem estar produzindo quimiocinas e citocinas pró-inflamatórias e EROs que atraem células apresentadoras de antígenos para o foco lesionado, fagocitando as células mortas e as apresentando para os linfócitos T, ou seja, amplificando a resposta inflamatória [21]. Ainda animais nocautes para as cadeias dos receptores dos linfócitos $\mathrm{T}$ alfa/beta e gama/delta submetidos à lesão de $\mathrm{I} / \mathrm{R}$ renal apresentaram-se protegidos da lesão de I/R renal, demonstrando que a ativação via TCR dos linfócitos apresenta um papel importante na fisiopatologia desencadeada pela lesão de I/R.

Portanto, os achados observados em nosso estudo demonstram maior expressão de RNAm de HO-1, T-bet e MCP-1 nos camundongos deficientes em IL-4 (representando um defeito da via Th2 da resposta imune), diretamente relacionados a um maior grau de comprometimento funcional e morfológico renal neste grupo, em comparação com os camundongos deficientes em IL-12 (representando um defeito da via Th1).

Reforçando nossos dados, quando realizamos a transferência adotiva de células totais da medula óssea de camundongos deficientes de IL-10 para animais selvagens previamente irradiados submetidos à lesão de I/R, esses animais apresentaram-se protegidos da lesão de I/R, favorecendo a hipótese da influência deletéria das células Th1, como um possível mecanismo efetor das células $\mathrm{T} C \mathrm{CD} 4+$ na lesão renal induzida pela $\mathrm{I} / \mathrm{R}$. Esta 
proteção foi corroborada pelos dados histológicos e pela baixa expressão de IL-6. Estes dados também demonstram que as células derivadas da medula óssea são as responsáveis pela lesão e produção de citocinas na lesão renal aguda.

Poucos trabalhos demonstram resultados com animais quiméricos submetidos à lesão de I/R. O grupo de Okusa e colegas demonstrou que animais noucates para Rag-1 eram protegidos da lesão de $\mathrm{I} / \mathrm{R}$ renal, mas, quando esses animais eram reconstituídos com linfócitos T CD4+, a lesão renal era restaurada [136]. Outro grupo publicou recentemente que animais nocautes para a quimiocina CCR2 eram protegido da lesão de I/R renal, mas, após a transferência adotiva de células totais da medula óssea de animais selvagens, a lesão era restaurada [43].

Por fim, fomos analisar três citocinas importantes na lesão renal aguda no soros dos animais isquemiados. A IL-4, envolvida principalmente com o perfil Th2, a IL6, uma citocina pró-inflamatória, e a $\mathrm{KC}$, que é uma quimiocina que faz quimiotaxia para neutrófilos e são produzidas principalmente pelos macrófagos. Detectamos maior concentração da citocina IL-6 no soro dos animais que não foram protegidos da lesão de I/R, como os animais nocaute para IL-4, IL-10 e IL-10/IL-12, enquanto que os animais protegidos não tiveram a presença de IL-6 no soro. Esses dados corroboram com os dados encontrados na análise pela expressão de RNAm de IL-6. A quimiocina KC se demonstrou em maior concentração também no soro de animais que não foram protegidos da lesão de I/R renal, indicando que esses animais possam ter um maior infiltrado de neutrófilos no rim em 24 horas.

Por outro lado, a concentração da citocina IL-4 foi maior no soro dos animais protegidos da lesão de I/R renal, como nos animais nocautes para IL-12 e duplo-nocautes para IFN- $\gamma /$ IL12, e ausentes nos animais nocaute para IL-4, IL-10 e duplo nocaute para IL-10/IL-12. Esses resultados apenas reforçam a idéia de que a citocina IL-12 tem um papel importante na lesão de I/R renal.

Vanessa N. de Paiva 
A nossa principal conclusão é que a IL-12 é a principal citocina responsável pela resposta imune que leva à ativação de linfócitos $\mathrm{T}$ na lesão de $\mathrm{I} / \mathrm{R}$ renal. Nossos resultados estimulam estudos sobre a ativação de células dendríticas e sobre a participação isolada de linfócitos T CD4+ na agressão renal isquêmica. 
6. Considerações Finais 
Apesar dos recentes avanços científicos, a lesão renal isquêmica continua sendo um dos principais indicadores de pior prognóstico funcional tanto nos rins nativos quanto nos rins transplantados, cursando com altas taxas de morbidade e mortalidade e altos índices de pior sobrevida dos enxertos renais e dos pacientes acometidos.

Os efeitos deletérios da lesão renal induzida pela I/R envolvem a participação de uma resposta inflamatória manifestada pelo desenvolvimento de disfunção endotelial, infiltração leucocitária e geração de mediadores inflamatórios pelas células epiteliais tubulares. A ativação endotelial promove a expressão aumentada de diferentes moléculas de adesão, com conseqüente recrutamento e infiltração de células efetoras, a indução e a ativação de genes inflamatórios como IL-1, TNF- $\alpha$, TGF- $\beta$ e MCP-1. Durante o processo de reperfusão as células endoteliais estimuladas são propensas à adesão de leucócitos e plaquetas, com liberação de espécies reativas de oxigênio e uma variedade de citocinas e quimiocinas, exacerbando a reação inflamatória, levando à IRA.

A infiltração renal pelas células inflamatórias induzida pela lesão de I/R é um fenômeno detectado nas fases de iniciação, extensão e reparação que se seguem à isquemia, envolvendo a participação de neutrófilos, monócitos/macrófagos, linfócitos T e B e plaquetas, cada uma delas exercendo um papel modulador importante na patogênese da lesão renal. Evidências recentes sugerem um papel fundamental das células T CD4+ na determinação da agressão renal isquêmica, sendo aventada a hipótese do envolvimento do paradigma Th1/Th2 como o mecanismo efetor direto da lesão, com o efeito deletério das células Th1 e o efeito protetor das células Th2 sobre o parênquima renal isquemiado, dados já publicados pelo nosso grupo [82].

Assim, em um modelo experimental de 45 minutos de isquemia renal seguida de reperfusão, mostramos que os camundongos deficientes em IL-4, IL-10 e duplo deficiente em IL-10/IL-12, uma citocina diretamente envolvida com a diferenciação e manutenção da resposta Th2, cursaram com uma evidente e importante acentuação da lesão renal 
induzida pela $\mathrm{I} / \mathrm{R}$, em comparação com os animais deficientes em IL-12, uma citocina diretamente envolvida com a diferenciação e manutenção da resposta Th1. A influência deletéria da deficiência da IL-4, em relação à deficiência de IL-12, foram traduzidos por uma maior disfunção renal caracterizada pela elevação significante dos níveis séricos de creatinina, pela significância do maior grau de necrose tubular e menor grau de regeneração tubular observados na análise histomorfométrica, e os achados moleculares significantes da maior expressão de RNAm de HO-1 de um gene citoprotetor, e de genes pró-inflamatórios como IL-6 e MCP-1.

Tais achados são compatíveis com a hipótese de que a influência das células $\mathrm{T}$ $\mathrm{CD} 4+$ na lesão renal induzida pela lesão de I/R seja determinada pelos efeitos deletérios da via Th1 da resposta imune celular, possivelmente às custas de expressões gênicas elevadas de citocinas IL-6 e de quimiocinas pró-inflamatórias, como o MCP-1, em contraposição aos efeitos protetores da via Th2, através da maior expressão de moléculas citoprotetoras, como a HO-1, caracterizando a ruptura do balanço fisiológico Th1/Th2 provocada pela resposta inflamatória na $\mathrm{I} / \mathrm{R}$ renal.

Em suma, os resultados obtidos em nosso estudo permitem vislumbrar um possível mecanismo efetor das células T CD4 + na lesão de I/R renal, podendo contribuir para os avanços na melhor compreensão da fisiopatogênese da IRA isquêmica, bem como no desenvolvimento futuro de novas medidas para sua prevenção e tratamento.

\subsection{Perspectivas Futuras}

Um grande número de estudos analisando o papel das respostas imunes inata e adquirida vêm demonstrando resultados promissores, tanto no entendimento da doença como na perspectiva de atenuação do processo inflamatório agudo, desencadeado pela lesão de I/R renal.

Uma área de interesse crescente na prevenção da injúria renal pela $\mathrm{I} / \mathrm{R}$ é a do 
pré-condicionamento, através do qual já foi demonstrada proteção contra um insulto isquêmico subsequente [156]. Da mesma forma, opções terapêuticas eficientes para a IRA induzida pela lesão de $\mathrm{I} / \mathrm{R}$ são sugeridas em estudos experimentais com o uso da CTLA-4-Ig [16, 115], com anticorpos monoclonais humanizados anti-B7 [157], e com as preparações de globulinas anti-timocíticas (que contêm muitos anticorpos direcionados contra várias moléculas de adesão) [158, 159]. Por exemplo, a co-administração de um agonista dos receptores de adenosina-A2A com um inibidor da fosfodiesterase do tipo IV foi mais efetiva do que o uso isolado de cada um destes agentes para inibir a atividade oxidativa de neutrófilos humanos e na inibição da lesão provocada pela I/R em rins de camundongos [158].

A indução terapêutica da expressão elevada de HO-1, tentada através de diversas modalidades como com as metalo-proteínas (CoPP e FePP), e o tratamento com o monóxido de carbono, que reproduz a proteção promovida pela HO-1, reduz a lesão isquêmica em uma série de modelos experimentais de $\mathrm{I} / \mathrm{R}$ e transplantes, através do aumento da expressão de proteínas anti-apoptóticas, inibindo a expressão de moléculas de adesão endotelial e a aterosclerose acelerada [160]. Constitui-se, portanto, em recurso preventivo e terapêutico promissor na IRA isquêmica e no desenvolvimento da nefropatia crônica do transplante renal.

$\mathrm{Na}$ área do transplante renal, a lesão induzida pela I/R exerce papel importante no desenvolvimento da função tardia do enxerto e nas alterações em longo prazo sobre o rim transplantado, que estão intimamente relacionadas com o processo de nefropatia crônica do transplante. O aprimoramento de estratégias terapêuticas que melhorem a disfunção da célula endotelial e a infiltração celular poderá prevenir o dano em longo prazo da I/R sobre o transplante renal [161].

Assim, os resultados obtidos em nosso estudo sugerem que o paradigma Th1/Th2 de diferenciação das células T CD4+ exerça um papel fundamental na resposta infla- 
matória da lesão renal induzida pela I/R, sendo tais achados de grande importância para o aperfeiçoamento dos conhecimentos da complexa fisiopatologia da I/R renal. Todos estes conceitos seriam contribuirão para o desenvolvimento de novas técnicas de prevenção e de tratamento da lesão renal aguda isquêmica tanto nos rins nativos e como no transplante renal. 


\section{Conclusões}


1. O modelo experimental de $\mathrm{I} / \mathrm{R}$ utilizado promoveu lesão renal grave confirmado pelos níveis séricos elevados de creatinina e pela necrose tubular extensa na medula renal comprovado pela analíse histomorfométrica;

2. O maior grau de comprometimento da função renal e a maior severidade da necrose tubular aguda foram encontrados nos camundongos nocautes para IL-4, IL-10/IL12 e IL-10 (representando defeito da via Th2) e IFN- $\gamma$ em comparação com os camundongos deficientes em IL-12 e IFN- $\gamma /$ IL-12 (representando defeito da via Th1), sugerindo uma influência deletéria da via Th1 da resposta imune e uma influência protetora da via Th2 na lesão renal induzida pela I/R renal;

3. A influência deletéria da via Th1 da resposta na lesão renal induzida pela I/R, poderia estar relacionada à maior e mais sustentada expressão de citocinas próinflamatórias como IL-6 e a persistência de célula T no sítio de agressão caracterizada pela significante expressão de T-bet;

4. A lesão de I/R está relacionada com a expressão de proteínas citoprotetoras, como a HO-1, e esta resposta se correlacionou com o grau com de inflamação, aferida pelo nível de RNAm de IL-6;

5. A lesão de I/R se associou com elevados níveis séricos de IL-6 e KC e baixa quantidade de IL-4, especialmente nos animais que apresentaram severa disfunção renal nos animais nocautes IFN- $\gamma$, IL-10 e IL-10/IL-12; a proteção à lesão renal observada nos animais IL-12 e IFN- $\gamma /$ IL-12 se associou com menores expressores de IL-6 e KC e maior de IL-4;

6. A transferência de medula óssea de animais nocautes para IL-12 conferiu proteção aos animais selvagens representada por menores níveis de uréia sérica, menores taxas de necrose tubular agudar e menor expressão de RNAm de IL-6; 


\section{Referências Bibliográficas}

[1] Friedewald JJ, Rabb H. Inflammatory cells in ischemic acute renal failure. Kidney Int. 2004;66(2):486-491.

[2] Schlichting CL, Schareck WD, Weis M. Renal ischemia-reperfusion injury: new implications of dendritic cell-endothelial cell interactions. Transplant Proc. 2006;38(3):670-673.

[3] Thadhani RI, Camargo J C A, Xavier RJ, Fang LS, Bazari H. Atheroembolic renal failure after invasive procedures. Natural history based on 52 histologically proven cases. Medicine (Baltimore). 1995;74(6):350-358.

[4] Bonventre JV, Weinberg JM. Recent advances in the pathophysiology of ischemic acute renal failure. J Am Soc Nephrol. 2003;14(8):2199-2210.

[5] Molitoris BA. Acute renal failure. Drugs Today (Barc). 1999;35(9):659-666.

[6] Hamel MB, Phillips RS, Davis RB, Desbiens N, Connors J A F, Teno JM, et al. Outcomes and cost-effectiveness of initiating dialysis and continuing aggressive care in seriously ill hospitalized adults. SUPPORT Investigators. Study to Understand Prognoses and Preferences for Outcomes and Risks of Treatments. Ann Intern Med. 1997;127(3):195-202.

[7] Cecka M. Clinical outcome of renal transplantation. Factors influencing patient and graft survival. Surg Clin North Am. 1998;78(1):133-148. 
[8] Scannell G. Leukocyte responses to hypoxic/ischemic conditions. New Horiz. $1996 ; 4(2): 179-183$.

[9] Molitoris BA, Sutton TA. Endothelial injury and dysfunction: role in the extension phase of acute renal failure. Kidney Int. 2004;66(2):496-499.

[10] Rabb H, Wang Z, Nemoto T, Hotchkiss J, Yokota N, Soleimani M. Acute renal failure leads to dysregulation of lung salt and water channels. Kidney Int. 2003;63(2):600-6.

[11] Bonventre JV, Zuk A. Ischemic acute renal failure: an inflammatory disease? Kidney Int. 2004;66(2):480-485.

[12] Rabb H, Postler G. Leucocyte adhesion molecules in ischaemic renal injury: kidney specific paradigms? Clin Exp Pharmacol Physiol. 1998;25(3-4):286-291.

[13] Linask KK, Ludwig C, Han MD, Liu X, Radice GL, Knudsen KA. Ncadherin/catenin-mediated morphoregulation of somite formation. Dev Biol. 1998;202(1):85-102.

[14] Willinger CC, Schramek H, Pfaller K, Pfaller W. Tissue distribution of neutrophils in postischemic acute renal failure. Virchows Arch B Cell Pathol Incl Mol Pathol. 1992;62(4):237-243.

[15] Rabb H. Role of leukocytes and leukocyte adhesion molecules in renal ischemicreperfusion injury. Front Biosci. 1996;1:e9-14.

[16] Takada M, Chandraker A, Nadeau KC, Sayegh MH, Tilney NL. The role of the B7 costimulatory pathway in experimental cold ischemia/reperfusion injury. J Clin Invest. 1997;100(5):1199-1203. 
[17] Kelly KJ, Williams J W W, Colvin RB, Bonventre JV. Antibody to intercellular adhesion molecule 1 protects the kidney against ischemic injury. Proc Natl Acad Sci U S A. 1994;91(2):812-816.

[18] Deng J, Kohda Y, Chiao H, Wang Y, Hu X, Hewitt SM, et al. Interleukin10 inhibits ischemic and cisplatin-induced acute renal injury. Kidney Int. 2001;60(6):2118-2128.

[19] Takahira R, Yonemura K, Fujise Y, Hishida A. Dexamethasone attenuates neutrophil infiltration in the rat kidney in ischemia/reperfusion injury: the possible role of nitroxyl. Free Radic Biol Med. 2001;31(6):809-815.

[20] Singbartl K, Green SA, Ley K. Blocking P-selectin protects from ischemia/reperfusion-induced acute renal failure. Faseb J. 2000;14(1):48-54.

[21] Gandolfo MT, Rabb H. Very early alloantigen-independent trafficking of lymphocytes during ischemic acute kidney injury. Kidney Int. 2007;71(12):1193-1195.

[22] Bonventre JV. Phospholipase A2 and signal transduction. J Am Soc Nephrol. 1992;3(2):128-150.

[23] Feitoza CQ, Camara NO, Pinheiro HS, Goncalves GM, Cenedeze MA, PachecoSilva A, et al. Cyclooxygenase 1 and/or 2 blockade ameliorates the renal tissue damage triggered by ischemia and reperfusion injury. Int Immunopharmacol. $2005 ; 5(1): 79-84$.

[24] Matsuyama M, Nakatani T, Hase T, Kawahito Y, Sano H, Kawamura M, et al. The expression of cyclooxygenases and lipoxygenases in renal ischemia-reperfusion injury. Transplant Proc. 2004;36(7):1939-1942.

[25] Feitoza CQ, Gonçalves GM, Semedo P, Cenedeze MA, Pinheiro HS, Beraldo FC, 
et al. Inhibition of Cox 1 and 2 prior to renal ischemia-reperfusion injury (IRI) decreases the development of fibrosis. Mol Med. 2008;A ser publicado.

[26] Jassem W, Heaton ND. The role of mitochondria in ischemia/reperfusion injury in organ transplantation. Kidney Int. 2004;66(2):514-517.

[27] Cines DB, Pollak ES, Buck CA, Loscalzo J, Zimmerman GA, McEver RP, et al. Endothelial cells in physiology and in the pathophysiology of vascular disorders. Blood. 1998;91(10):3527-3561.

[28] Ysebaert DK, De Greef KE, Vercauteren SR, Ghielli M, Verpooten GA, Eyskens EJ, et al. Identification and kinetics of leukocytes after severe ischaemia/reperfusion renal injury. Nephrol Dial Transplant. 2000;15(10):15621574 .

[29] Rabb H, Ramirez G, Saba SR, Reynolds D, Xu J, Flavell R, et al. Renal ischemicreperfusion injury in L-selectin-deficient mice. Am J Physiol. 1996;271(2 Pt 2):F408-13.

[30] Kluth DC. Pro-resolution properties of macrophages in renal injury. Kidney Int. $2007 ; 72(3): 234-236$.

[31] Li L, Huang L, Sung SS, Lobo PI, Brown MG, Gregg RK, et al. NKT cell activation mediates neutrophil IFN-gamma production and renal ischemia-reperfusion injury. J Immunol. 2007;178(9):5899-5911.

[32] Dong X, Swaminathan S, Bachman LA, Croatt AJ, Nath KA, Griffin MD. Resident dendritic cells are the predominant TNF-secreting cell in early renal ischemiareperfusion injury. Kidney Int. 2007;71(7):619-628.

[33] Wu CJ, Sheu JR, Chen HH, Liao HF, Yang YC, Yang S, et al. Modulation of 
monocyte-derived dendritic cell differentiation is associated with ischemic acute renal failure. J Surg Res. 2006;132(1):104-111.

[34] Arumugam TV, Shiels IA, Woodruff TM, Granger DN, Taylor SM. The role of the complement system in ischemia-reperfusion injury. Shock. 2004;21(5):401-9.

[35] Sacks SH, Chowdhury P, Zhou W. Role of the complement system in rejection. Curr Opin Immunol. 2003;15(5):487-92.

[36] De Vries B, Matthijsen RA, Wolfs TG, Van Bijnen AA, Heeringa P, Buurman WA. Inhibition of complement factor C5 protects against renal ischemiareperfusion injury: inhibition of late apoptosis and inflammation. Transplantation. $2003 ; 75(3): 375-382$.

[37] Takeda K, Akira S. TLR signaling pathways. Semin Immunol. 2004;16(1):3-9.

[38] Land W. Postischemic reperfusion injury to allografts - a case for 'innate immunity'? Eur Surg Res. 2002;34(1-2):160-169.

[39] Leemans JC, Stokman G, Claessen N, Rouschop KM, Teske GJ, Kirschning CJ, et al. Renal-associated TLR2 mediates ischemia/reperfusion injury in the kidney. J Clin Invest. 2005;115(10):2894-2903.

[40] Body-Malapel M, Dharancy S, Berrebi D, Louvet A, Hugot JP, Philpott DJ, et al. NOD2: a potential target for regulating liver injury. Laborat Invest. $2008 ; 88(3): 318-327$.

[41] Fiorina P, Ansari MJ, Jurewicz M, Barry M, Ricchiuti V, Smith RN, et al. Role of CXC chemokine receptor 3 pathway in renal ischemic injury. J Am Soc Nephrol. $2006 ; 17(3): 716-723$. 
[42] Cugini D, Azzollini N, Gagliardini E, Cassis P, Bertini R, Colotta F, et al. Inhibition of the chemokine receptor CXCR2 prevents kidney graft function deterioration due to ischemia/reperfusion. Kidney Int. 2005;67(5):1753-1761.

[43] Li L, Huang L, Sung SS, Vergis AL, Rosin DL, Rose CEJ, et al. The chemokine receptors CCR2 and CX3CR1 mediate monocyte/macrophage trafficking in kidney ischemia-reperfusion injury. Kidney Int. 2008;A ser publicado.

[44] Lichtman AH, Abbas AK. T-cell subsets: recruiting the right kind of help. Curr Biol. 1997;7(4):R242-R244.

[45] Burne MJ, Daniels F, El Ghandour A, Mauiyyedi S, Colvin RB, O’Donnell MP, et al. Identification of the CD4(+) T cell as a major pathogenic factor in ischemic acute renal failure. J Clin Invest. 2001;108(9):1283-1290.

[46] Pinheiro HS, Camara NO, Noronha IL, Maugeri IL, Franco MF, Medina JO, et al. Contribution of CD4 $+\mathrm{T}$ cells to the early mechanisms of ischemia- reperfusion injury in a mouse model of acute renal failure. Braz J Med Biol Res. 2007;40(4):557568.

[47] Burne-Taney MJ, Ascon DB, Daniels F, Racusen L, Baldwin W, Rabb H. B cell deficiency confers protection from renal ischemia reperfusion injury. J Immunol. 2003;171(6):3210-3215.

[48] Burne-Taney MJ, Yokota-Ikeda N, Rabb H. Effects of combined T- and B-cell deficiency on murine ischemia reperfusion injury. Am J Transplant. 2005;5(6):11861193.

[49] Day YJ, Huang L, Ye H, Li L, Linden J, Okusa MD. Renal ischemia-reperfusion injury and adenosine $2 \mathrm{~A}$ receptor-mediated tissue protection: the role of $\mathrm{CD} 4+\mathrm{T}$ cells and IFN-gamma. J Immunol. 2006;176(5):3108-14. 
[50] Boismenu R, Havran WL. An innate view of gamma delta T cells. Curr Opin Immunol. 1997;9(1):57-63.

[51] Ladel CH, Blum C, Kaufmann SH. Control of natural killer cell-mediated innate resistance against the intracellular pathogen Listeria monocytogenes by gamma/delta T lymphocytes. Infect Immun. 1996;64(5):1744-1749.

[52] Savransky V, Molls RR, Burne-Taney M, Chien CC, Racusen L, Rabb H. Role of the T-cell receptor in kidney ischemia-reperfusion injury. Kidney Int. 2006;69(2):233-238.

[53] Ascon DB, Ascon M, Satpute S, Lopez-Briones S, Racusen L, Colvin RB, et al. Normal mouse kidneys contain activated and CD3+ CD4- CD8- double-negative T lymphocytes with a distinct TCR repertoire. J Leuk Biol. 2008; A ser publicado.

[54] Caton AJ, Cozzo C, Larkin JR, Lerman MA, Boesteanu A, Jordan MS. CD4(+) CD25(+) regulatory T cell selection. Ann N Y Acad Sci. 2004;1029:101-114.

[55] Liu M, Zheng S, Wang X, Wen Z. Regulatory roles of IL-12, IL-4 and IFN-gamma on IgE synthesis in atopic patients. Chin Med J. 1999;112(6):550-553.

[56] Poltoral A, He XL, Smirnova I, Van Huffel C, Du X, Birdwell D, et al. Defective LPS signaling in $\mathrm{C} 3 \mathrm{H} / \mathrm{HeJ}$ and C57BL/10ScCr mice: mutations in Tlr4 gene. Science;282.

[57] Trinchieri G. Immunobiology of interleukin-12. Immunol Research. 1998;17:269178.

[58] Bacon CM, Petricoin EF, Ortaldo JR, Rees RC, Larner AC, Johnston JA, et al. Interleukin-12 induces tyrosine phosphorylation and activation of STAT-4 in human-lymphocytes. Proc Natl Acad Sci U S A. 1995;92:7307-7311. 
[59] Bacon CM, Mcvicar DW, Ortaldo JR, Rees RC, Larner AC, Johnston JA, et al. Interleukin-12 (IL-12) induces tyrosine phosphorylation of JAK2 and TYK2 differential use of Janus family tyrosine kinases by IL-2 e IL-12. J Exp Med. 1995;181:399-404.

[60] Interleukin-12 and the regulation of innate resistance and daptive immunity. Nature Rev Immun. 2003;3:133-146.

[61] Oppmann B, Lesley R, Blom B, Timans JC, Xu YM, Hunte B, et al. Novel p19 protein angages IL-12p40 to form a cytokine, IL-23. Immunity. 2000;13:715-725.

[62] Stobie L, Gurunathan S, Prussin C, Sacks DL, Glaichenhaus N, Wu CY, et al. The role of antigen and IL-12 in sustaining Th1 memory cells in vivo: IL-12 is required to maintain memory/effector Th1 cells sufficient to mediate protection to an infectious parasite challenge. Proc Natl Acad Sci U S A. 2000;97(15):8427-8432.

[63] Mattner F, Magram J, Ferrante J, Launois P, DiPadova K, Behin R, et al. Genetically resistant mice lacking interleukin-12 are susceptible to infection with Leishmania major and mount a polarized Th2 cell response. Eur J Immunol. 1996;26:1553-1559.

[64] Frucht DM, Fukao T, Bogdan C, Schindler H, O’Shea JJ, Koyasu S. IFN-gamma production by antigen-presenting cells: mechanisms emerge. Trend Immunol. 2001;22:556-560.

[65] Isaacs A, Burke DC, Fadeeva L. Effect of interferon on the growth of viruses on the chick chorion. Brit J Exp Pathol. 1958;39:477-451.

[66] Isaacs A, Burke DC. Mode of action of interferon. Nature. 1958;182:1073-1074.

[67] Burke DC, Isaacs A. Further studies on interferon. Brit J Exp Patol. 1958;39(1):7884. 
[68] Spellberg B, Edwards JE. Type 1/ Type 2 immunity in infectious diseases. Clin Infec Dis. 2001;32(1):76-102.

[69] Boehm U, Klamp T, Groot M, Howard JC. Cellular responses to interferongamma. Ann Rev Immunol. 1997;15:749-795.

[70] Mountford AP, Coulson PS, Cheever AW, Sher A, Wilson RA, Wynn TA. Interleukin-12 can directly induce T-helper 1 responses in interferon-gamma (IFNgamma) receptor-deficient mice, but requires IFN-gamma signalling to downregulate T-helper 2 responses. Immunology. 1999;97(4):588-594.

[71] Tau G, Rothman P. Biologic functions of the IFN-gamma receptors. Allergy. 1999;54(12):1233-1251.

[72] Shtrichman R, Samuel CR. The role of gamma interferon in antimicrobial immunity. Curr Op Microb. 2001;4(3):251-259.

[73] Samuel CE. Antiviral actions of interferons. Clin Microb Rev. 2001;14:778-809.

[74] DelPrete G, Decarli M, Almerigogna F, Giudizi MG, Biagiotti R, Romagnani S. Human IL-10 is produced by both type 1 helper (Th1) and type 2 helper (Th2) T cell clones and inhibits their antigen-specific proliferation and cytokine production. J Immunol. 1993;4(3):353-360.

[75] Taylor SC, Shacks SJ, Qu ZW, Wiley P. Type 2 cytokine serum levels in healthy sickle cell disease patients. J Natl Med Assoc. 1997;89(11):753-757.

[76] Mueller TD, Zhang JL, Sebald W, Duschi A. Structure, binding, and antagonists in the IL-4/IL-13 receptor system. Bioch Bioph Acta-Mol Cell Res. 2002;1592(3):237250. 
[77] Nakayama T, Yamashita M. Initiation and maintenance of Th2 cell identify. Curr Op Immunol. 2008;20(3):265-271.

[78] Thauland TJ, Koguchi Y, Wetzel SA, Dustin ML, Parker DC. Th1 and Th2 cells form morphologically distinct immunological synapses. J Immunol. 2008;181(1):392-399.

[79] Schmidt-Weber CB, Akdis M, Akdis CA. TH17 cells in the big picture of immunology. J Allergy Clin Immunol. 2007;120(2):247-254.

[80] Kurts C. Th17 Cells: a third subset of CD4(+) T effector cells involved in organspecific autoimmunity. Neph Dial Transplant. 2008;23(3):816-819.

[81] Yokota N, Burne-Taney M, Racusen L, Rabb H. Contrasting roles for STAT4 and STAT6 signal transduction pathways in murine renal ischemia-reperfusion injury. Amer J Physiol Renal Physiol. 2003;285(2):F319-F325.

[82] Marques VP, Goncalves GM, Feitoza CQ, Cenedeze MA, Fernandes Bertocchi AP, Damiao MJ, et al. Influence of TH1/TH2 switched immune response on renal ischemia-reperfusion injury. Nephron Exp Nephrol. 2006;104(1):e48-56.

[83] Yet SF, Perrella MA, Layne MD, Hsieh CM, Maemura K, Kobzik L, et al. Hypoxia induces severe right ventricular dilatation and infarction in heme oxygenase- 1 null mice. J Clin Invest. 1999;103(8):R23-29.

[84] Kitada O, Kodama T, Kuribayashi K, Ihaku D, Fujita M, Matsuyama T, et al. Heme oxygenase-1 (HO-1) protein induction in a mouse model of asthma. Clin Exp Allergy. 2001;31(9):1470-1477.

[85] Sharma HS, Maulik N, Gho BC, Das DK, Verdouw PD. Coordinated expression of heme oxygenase- 1 and ubiquitin in the porcine heart subjected to ischemia and reperfusion. Mol Cell Biochem. 1996;157(1-2):111-116. 
[86] Maines MD. The heme oxygenase system: a regulator of second messenger gases. Annu Rev Pharmacol Toxicol. 1997;37:517-554.

[87] Shibahara S, Nakayama M, Kitamuro T, Udono-Fujimori R, Takahashi K. Repression of heme oxygenase-1 expression as a defense strategy in humans. Exp Biol Med (Maywood). 2003;228(5):472-473.

[88] Otterbein LE, Soares MP, Yamashita K, Bach FH. Heme oxygenase-1: unleashing the protective properties of heme. Trends Immunol. 2003;24(8):449-455.

[89] McCoubrey WKJ, Huang TJ, Maines MD. Heme oxygenase-2 is a hemoprotein and binds heme through heme regulatory motifs that are not involved in heme catalysis. J Biol Chem. 1997;272(19):12568-12574.

[90] McCoubrey WKJ, Huang TJ, Maines MD. Isolation and characterization of a cDNA from the rat brain that encodes hemoprotein heme oxygenase-3. Eur J Bioc. 1997;247(2):725-732.

[91] Zhuang H, Pin S, Li XL, Dore S. Regulation of heme oxygenase expression by cyclopentenone prostaglandins. Exp Biol Med. 2003;228(5):499-505.

[92] Scapagnini G, D’Agata V, Calabrese V, Pascale A, Colombrita C, Alkon D, et al. Gene expression profiles of heme oxygenase isoforms in the rat brain. Brain Resear. 2002;954(1):51-59.

[93] Singleton JW, Laster L. Biliverdin reductase of guinea pig liver. J Biol Chem. 1965;240(12):4780-4789.

[94] P OC, Colleran E. Properties and kinetics of biliverdin reductase. Biochem J. $1971 ; 125(4): 110 \mathrm{P}$. 
[95] Ferris CD, Jaffrey SR, Sawa A, Takahashi M, Brady SD, Barrow RK, et al. Haem oxygenase-1 prevents cell death by regulating cellular iron. Nat Cell Biol. 1999;1(3):152-157.

[96] Balla G, Jacob HS, Balla J, Rosenberg M, Nath K, Apple F, et al. Ferritin: a cytoprotective antioxidant strategem of endothelium. J Biol Chem. 1992;267(25):18148-18153.

[97] Foresti R, Goatly H, Green CJ, Motterlini R. Role of heme oxygenase-1 in hypoxiareoxygenation: requirement of substrate heme to promote cardioprotection. Am J Physiol Heart Circ Physiol. 2001;281(5):H1976-H1984.

[98] Stocker R, Yamamoto Y, McDonagh AF, Glazer AN, Ames BN. Bilirubin is an antioxidant of possible physiological importance. Science. 1987;235(4792):10431046.

[99] Baranano DE, Rao M, Ferris CD, Snyder SH. Biliverdin reductase: a major physiologic cytoprotectant. Proc Natl Acad Sci U S A. 2002;99(25):16093-16098.

[100] Soares MP, Seldon MP, Gregoire IP, Vassilevskaia T, Berberat PO, Yu J, et al. Heme oxygenase-1 modulates the expression of adhesion molecules associated with endothelial cell activation. J Immunol. 2004;172(6):3553-3563.

[101] Brouard S, Otterbein LE, Anrather J, Tobiasch E, Bach FH, Choi AM, et al. Carbon monoxide generated by heme oxygenase 1 suppresses endothelial cell apoptosis. J Exp Med. 2000;192(7):1015-10126.

[102] Feitoza CQ, Goncalves GM, Bertocchi AP, Wang PW, Damiao MJ, Cenedeze MA, et al. A role for HO-1 in renal function impairment in animals subjected to ischemic and reperfusion injury and treated with immunosuppressive drugs. Transplant Proc. 2007;39(2):424-426. 
[103] Goncalves GM, Cenedeze MA, Feitoza CQ, de Paula CB, Macusso GD, Pinheiro HS, et al. Heme oxygenase 1 and renal ischemia and reperfusion injury: the impact of immunosuppressive drug. Int Immunopharmacol. 2006;6(13-14):1966-1972.

[104] Kelly KM. Does increasing oxygen delivery improve outcome? Yes. Crit Care Clin. 1996;12(3):635-644.

[105] Edwards ND, Callaghan LC, White T, Reilly CS. Perioperative myocardial ischaemia in patients undergoing transurethral surgery: a pilot study comparing general with spinal anaesthesia. Br J Anaesth. 1995;74(4):368-372.

[106] Halloran PF, Schlaut J, Solez K, Srinivasa NS. The significance of the anti-class I response. II. Clinical and pathologic features of renal transplants with anti-class I-like antibody. Transplantation. 1992;53(3):550-555.

[107] Solez K, Morel-Maroger L, Sraer JD. The morphology of "acute tubular necrosis"in man: analysis of 57 renal biopsies and a comparison with the glycerol model. Medicine (Baltimore). 1979;58(5):362-376.

[108] Pfaffl MW, Horgan GW, Dempfle L. Relative expression software tool (REST) for group-wise comparison and statistical analysis of relative expression results in real-time PCR. Nucleic Acids Res. 2002;30(9):e36.

[109] Patel NSA, Chatterjee PK, Di Paola R, Mazzon E, Britti D, De Sarro A, et al. Endogenous interleukin-6 enhances the renal injury, dysfunction, and inflammation caused by ischemia/reperfusion. J Pharm Exp Therap. 2005;312(3):1170-1178.

[110] Hassoun HT, Grigoryev DN, Lie ML, Liu MC, Cheadie C, Tuder RM, et al. Ischemic acute kidney injury induces a distant organ functional and genomic response distinguishable from bilateral nephrectomy. Amer J Physiol Renal Physiol. 2007;293(1):F30-F40.

Vanessa N. de Paiva 
[111] Jang HR, Rabb H. The innate immune response in ischemic acute kidney injury. Clin Immunol. 2008;

[112] Kinsey GR, Li L, Okusa MD. Inflammation in acute kidney injury. Neph Exp Neph. 2008;109(4):E102-E107.

[113] Cole N, Bao SS, Thakur A, Willcox M, Husband AJ. KC production in the cornea in response to Pseudomonas aeruginosa challenge. Immunol Cell Biol. 2000;78(1):1-4.

[114] Paul LC, de Fijter J, Boom H. Prolonged cold ischemia, late graft dysfunction, and cyclosporine in renal transplantation. Transplantation. 1999;68(7):925-926.

[115] Chandraker A, Takada M, Nadeau KC, Peach R, Tilney NL, Sayegh MH. CD28b7 blockade in organ dysfunction secondary to cold ischemia/reperfusion injury. Kidney Int. 1997;52(6):1678-1684.

[116] Rabb H, Daniels F, O’Donnell M, Haq M, Saba SR, Keane W, et al. Pathophysiological role of $\mathrm{T}$ lymphocytes in renal ischemia-reperfusion injury in mice. Am $\mathrm{J}$ Physiol Renal Physiol. 2000;279(3):F525-531.

[117] Di Giorno C, Pinheiro HS, Heinke T, Franco MF, Galante NZ, Pacheco-Silva A, et al. Beneficial effect of N-acetyl-cysteine on renal injury triggered by ischemia and reperfusion. Transplant Proc. 2006;38(9):2774-2776.

[118] Goncalves GM, Cenedeze MA, Feitoza CQ, de Paula CB, Marques GD, Pinheiro HS, et al. The role of immunosuppressive drugs in aggravating renal ischemia and reperfusion injury. Transplant Proc. 2007;39(2):417-420.

[119] Burne MJ, Haq M, Matsuse H, Mohapatra S, Rabb H. Genetic susceptibility to renal ischemia reperfusion injury revealed in a murine model. Transplantation. 2000;69(5):1023-1025. 
[120] Yokota N, Burne-Taney M, Racusen L, Rabb H. Contrasting roles for STAT4 and STAT6 signal transduction pathways in murine renal ischemia-reperfusion injury. Am J Physiol Renal Physiol. 2003;285(2):F319-325.

[121] Lee CM, Carter JT, Alfrey EJ, Ascher NL, Roberts JP, Freise CE. Prolonged cold ischemia time obviates the benefits of HLA mismatches in renal transplantation. Arch Surg. 2000;135(9):1016-9.

[122] Herrero-Fresneda I, Franquesa M, Torras J, Vidal A, Aran J, Pluvinet R, et al. Role of cold ischemia in acute rejection: characterization of a humoral-like acute rejection in experimental renal transplantation. Transplant Proc. 2005;37(9):37123715 .

[123] Yokota N, Daniels F, Crosson J, Rabb H. Prottective effect of T cell depletion in murine renal ischemia-reperfusion injury. Transplantation. 2002;74(6):759-63.

[124] Segerer S, Regele H, Mack M, Kain R, Cartron JP, Colin Y, et al. The Duffy antigen receptor for chemokines is up-regulated during acute renal transplant rejection and crescentic glomerulonephritis. Kidney Int. 2000;58(4):1546-1556.

[125] Zheng R, Cohen PA, Paustian CA, Johnson TD, Lee WT, Shu S, et al. Paired Tolllike receptor agonists enhance vaccine therapy through induction of interleukin-12. Cancer Resear. 2008;68(11):4045-4049.

[126] Basile DP, Donohoe D, Cao X, Van Why SK. Resistance to ischemic acute renal failure in the Brown Norway rat: a new model to study cytoprotection. Kidney Int. 2004;65(6):2201-2211.

[127] Chiao H, Kohda Y, McLeroy P, Craig L, Linas S, Star RA. Alpha-melanocytestimulating hormone inhibits renal injury in the absence of neutrophils. Kidney Int. 1998;54(3):765-774. 
[128] Ishibashi N, Weisbrot-Lefkowitz M, Reuhl K, Inouye M, Mirochnitchenko O. Modulation of chemokine expression during ischemia/reperfusion in transgenic mice overproducing human glutathione peroxidases. J Immunol. 1999;163(10):56665677.

[129] Zhou W, Patel H, Li K, Peng Q, Villiers MB, Sacks SH. Macrophages from C3deficient mice have impaired potency to stimulate alloreactive $\mathrm{T}$ cells. Blood. 2006;107(6):2461-2469.

[130] Bonventre JV. Kidney Injury Molecule-1 (KIM-1): a specific and sensitive biomarker of kidney injury. Scand J Clin Lab Invest. 2008;241:78-83.

[131] Klausner JM, Paterson IS, Goldman G, Kobzik L, Rodzen C, Lawrence R, et al. Postischemic renal injury is mediated by neutrophils and leukotrienes. Amer J Physiol. 1989;256(5):F794-F802.

[132] Tilney NL, Paz D, Ames J, Gasser M, Laskowski I, Hancock WW. Ischemiareperfusion injury. Transplant Proc. 2001;33(1-2):843-844.

[133] Laskowski I, Pratschke J, Wihelm MJ, Tilney NL. Molecular and cellular events associated with ischemia/reperfusion injury. Ann Transplant. 2000;5(4):29-35.

[134] Wang X, Li X, Schmidt DB, Foley JJ, Barone FC, Ames RS, et al. Identification and molecular characterization of rat CXCR3: receptor expression and interferon-inducible protein-10 binding are increased in focal stroke. Mol Pharmacol. 2000;57(8):1190-1198.

[135] Zhai Y, Qiao B, Gao F, Shen X, Vardanian A, Busuttil RW, et al. Type I, but not type II, interferon is critical in liver injury induced after ischemia and reperfusion. Hepatology. 2008;47(1):199-206. 
[136] Awad AS, Huang L, Ye H, Duong ET, Bolton WK, Linden J, et al. Adenosine A2A receptor activation attenuates inflammation and injury in diabetic nephropathy. Amer J Physiol Renal Physiol. 2006;290(4):F828-837.

[137] Murphey ED, Herndon DN, Sherwood ER. Gamma interferon does not enhance clearance of Pseudomonas aeruginosa but does amplify a proinflammatory response in a murine model of postseptic immunosuppression. Infect Immun. 2004;72(12):6892-901.

[138] Kimura-Shimmyo A, Kashiwamura S, Ueda H, et al. Cytokine-induced injury of the lacrimal and salivary glands. J Immunother (1997). 2002;25(1):S42-51.

[139] Chikano S, Sawada K, Shimoyama T, et al. IL-18 and IL-12 induce intestinal inflammatory and fatty liver in mice in an IFN-gamma dependent manner. Gut. $2000 ; 47(6): 779-786$.

[140] Qureshi MH, Harmsen AG, Gavry BA. IL-10 modulates host responses and lung damage induced by Pneumcystis carinii infection. J Immunol. 2003;170(2):10021009.

[141] Godet C, Goujon JM, Petit I, Lecron JC, Hauet T, Mauco G, et al. Endotoxin tolerance enhances interleukin-10 renal expression and decreases ischemia-reperfusion renal injury in rats. Shock. 2006;25(4):384-388.

[142] Nishimoto N, Kishimoto T. Humanized antihuman IL-6 receptor antibody, tocilizumab. Handbook Exp Pharmacol. 2008;181:151-160.

[143] Ivanov II, Zhou L, Littman DR. Transcriptional regulation of Th17 cell differentiation. Semin Immunol. 2007;19(6):409-417.

[144] Kaminska D, Tyran B, Mazanowska O, et al. Cytokine gene expression in kidney allograft biopsies after donor brain death and ischemia-reperfusion injury using 
in situ reverse-transcription polymerase chain reaction analysis. Transplantation. 2007;84(9):1118-1124.

[145] Tracz MJ, Juncos JP, Croatt AJ, et al. Deficiency of heme oxygenase-1 impairs renal hemodynamics and exaggerates systemic inflammatory responses to renal ischemia. Kidney Int. 2007;72(9):1073-80.

[146] Hart CM, Tolson JK, Block ER. Supplemental fatty acids alter lipid peroxidation and oxidant injury in endothelial cells. Amer J Physiol. 1991;260(6):L481-L488.

[147] Chauveau C, Rémy S, Royer PJ, Hill M, Tanguy-Royer S, Hubert FX, et al. Heme oxygenase-1 expression inhibits dendritic cell maturation and proinflammatory function but conserves IL-10 expression. Blood. 2005;106(5):1694-1702.

[148] Chen S, Kapturczak MH, Wasserfall C, Glushakova OY, Campbell-Thompson M, Deshane JS, et al. Interleukin 10 attenuates neointimal proliferation and inflammation in aortic allografts by a heme oxygenase-dependent pathway. Proc Natl Acad Sci U S A. 2005;102(20):7251-7256.

[149] Ke B, Shen XD, Gao F, Busuttil RW, Löwenstein PR, Castro MG, et al. Gene therapy for liver transplantation using adenoviral vectors: CD40-CD154 blockade by gene transfer of CD40Ig protects rat livers from cold ischemia and reperfusion injury. Mol Therapy. 2004;9(1):38-45.

[150] Camara NO, Soares MP. Heme oxygenase-1 (HO-1), a protective gene that prevents chronic graft dysfunction. Free Rad Biol Med. 2005;38(4):426-435.

[151] Delves PJ, Roitt IM. The immune system. First of two parts. N Engl J Med. 2000;343(1):37-49.

[152] Shoskes DA. Nonimmunologic renal allograft injury and delayed graft function: 
Vanessa Nunes de Paiva

\section{Participação das Citocinas Th1 e Th2 na Lesão de Isquemia e Reperfusão Renal}

Dissertação de mestrado apresentada ao Instituto de Ciências Biomédicas da Universidade de São Paulo, para obtenção do Título de Mestre em Ciências (Imunologia)

São Paulo

2008 
clinical strategies for prevention and treatment. Transplant Proc. 2000;32(4):766768.

[153] Rice JC, Spence JS, Yetman DL, Safirstein RL. Monocyte chemoattractant protein-1 expression correlates with monocyte infiltration in the post-ischemic kidney. Ren Fail. 2002;24(6):703-723.

[154] Matzinger P. Tolerance, danger, and the extended family. Annu Rev Immunol. 1994;12:991-1045.

[155] García J, Wagner G, Sömmo L, Lander P, Laguna P. Identification of the occluded artery in patients with myocardial ischemia induced by prolonged percutaneous transluminal coronary angioplasty using traditional vs transformed ECG-based indexes. Comput Biomed Res. 1999;32(5):470-482.

[156] Park KM, Chen A, Bonventre JV. Prevention of kidney ischemia/reperfusioninduced functional injury and JNK, p38, and MAPK kinase activation by remote ischemic pretreatment. J Biol Chem. 2001;276(15):11879-11876.

[157] De Greef KE, Ysebaert DK, Dauwe S, Persy V, Vercauteren SR, Mey D, et al. Anti-B7-1 blocks mononuclear cell adherence in vasa recta after ischemia. Kidney Int. 2001;60(4):1415-1427.

[158] Okusa MD, Linden J, Huang L, Rosin DL, Smith DF, Sullivan G. Enhanced protection from renal ischemia-reperfusion [correction of ischemia:reperfusion] injury with $\mathrm{A}(2 \mathrm{~A})$-adenosine receptor activation and PDE 4 inhibition. Kidney Int. 2001;59(6):2114-2125.

[159] Ysebaert DK, De Greef KE, De Beuf A, Van Rompay AR, Vercauteren S, Persy VP, et al. T cells as mediators in renal ischemia/reperfusion injury. Kidney Int. 2004;66(2):491-496. 
[160] Martins S, de Perrot M, Imai Y, Yamane M, Quadri SM, Segall L, et al. Transbronchial administration of adenoviral-mediated interleukin-10 gene to the donor improves function in a pig lung transplant model. Gene Ther. 2004;11(24):17861796.

[161] Gueler F, Gwinner W, Schwarz A, Haller H. Long-term effects of acute ischemia and reperfusion injury. Kidney Int. 2004;66(2):523-527. 


\section{Anexos}

Paper submitido para publicação na revista Immunopharmacology

CRITICAL INVOLVEMENT OF TH1-RELATED CYTOKINES IN RENAL INJURIES INDUCED BY ISCHEMIA AND REPERFUSION.

Vanessa Nunes de Paiva, Rebecca M. M. Monteiro, Vilmar de Paiva Marques, Mar-

cos Antonio Cenedeze, Vicente de P. A. Teixeira, Marlene A. dos Reis, Alvaro PachecoSilva1, Niels O. S. Câmara. 